
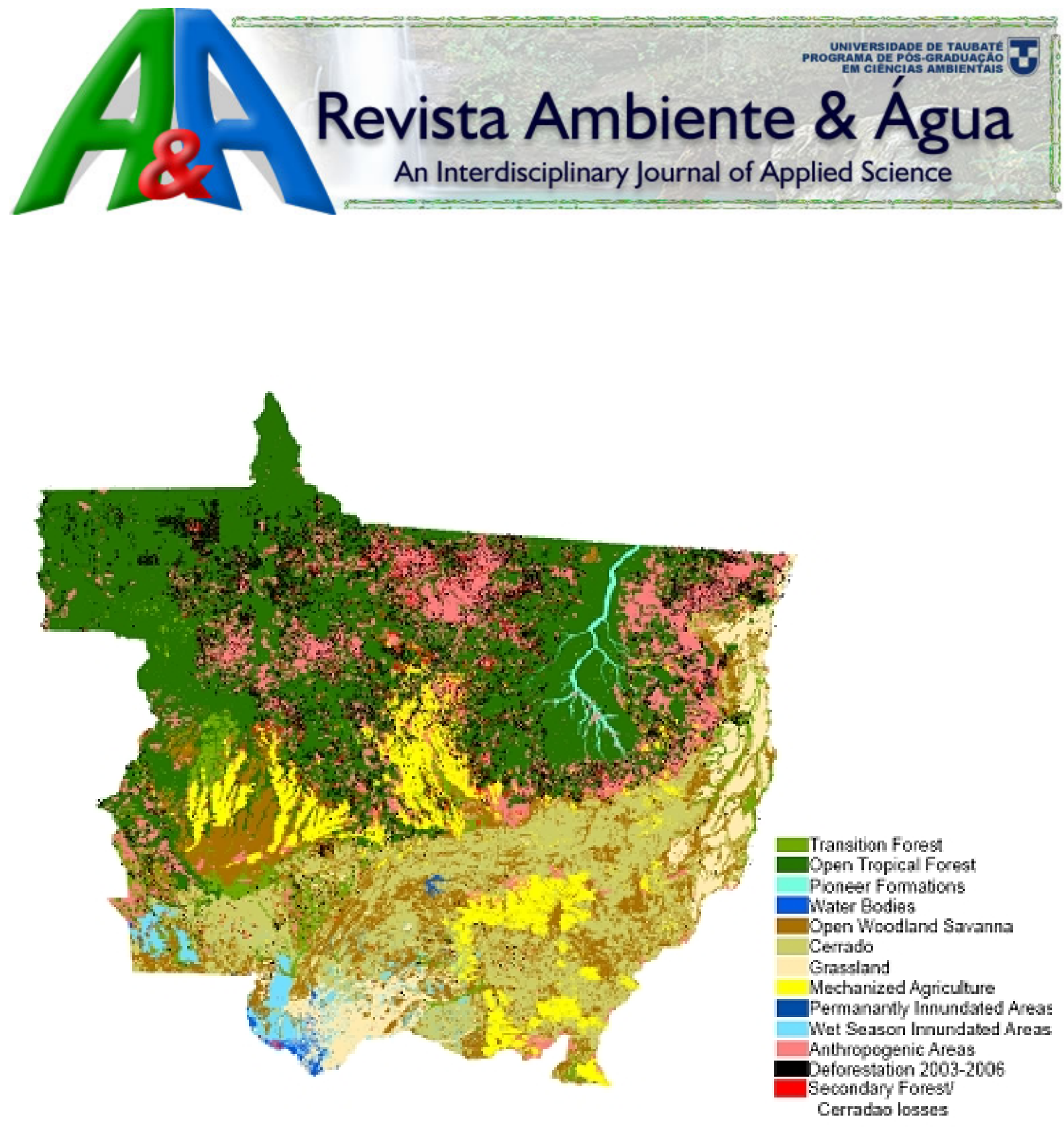

ISSN = 1980-993X (Online)

www.agro.unitau.br/ambi-agua

Edição 03 da Revista Ambiente \& Água - An Interdisciplinary Journal of Applied Science, Taubaté, v. 2, n. 1, p. 1-93, Abril 2007. (doi:10.4136/ambi-agua.v2.n1) 


\section{COMITÊ EDITORIAL}

\section{Editor}

Getulio Teixeira Batista

Instituto de Pesquisas Ambientais em Bacias Hidrográficas (IPABHi), Brasil

\section{Editores Associados}

Amaury Paulo de Souza

Universidade Federal de Viçosa (UFV), Brasil

Antonio Evaldo Klar

Universidade Estadual Paulista Júlio de Mesquita Filho, UNESP, Brasil

Dar Roberts

Universidade de Stanford; BA pela Universidade da Califórnia, EUA

Hans Raj Gheyi

Universidade Federal de Campina Grande (UFCG), Brasil

\section{Hélio Nóbile Diniz}

Instituto Geológico, Secretaria do Meio Ambiente do Estado de São Paulo (IG/SMA), Brasil

\section{João Vianei Soares}

Instituto Nacional de Pesquisas Espaciais (INPE), Brasil

Editor da Seção Editorial

Editora de Texto

Editora de Referência

Editor de Layout

Suporte Técnico
Luis A. Bartolucci

Florida International University (FIU), EUA

Marcelo dos Santos Targa

Universidade de Taubaté (UNITAU), Brasil

Nelson Wellausen Dias

Universidade de Taubaté (UNITAU), Brasil

Paul W. Mausel

Indiana State University (ISU), EUA

Paulo Renato Schneider

Universidade Federal de Santa Maria (UFSM), Brasil

Sebastião do Amaral Machado

Universidade Federal do Paraná (UFPR), Brasil

Silvio Jorge Coelho Simões

Universidade Estadual Paulista Júlio de Mesquita Filho (UNESP), Brasil

Yosio Edemir Shimabukuro

Instituto Nacional de Pesquisas Espaciais (INPE), Brasil

Nelson Wellausen Dias, PPGCA, UNITAU, Brasil

Maria de Jesus Ferreira Aires, GELP, UNITAU, Brasil

Liliane Castro, Biblioteca ECA/Civil, UNITAU, Brasil

Adam Querido Mazzei Ribeiro, LAGEO, UNITAU, Brasil

Marcio Vinicius Gagliotti, LAGEO, UNITAU, Brasil.

Ficha catalográfica elaborada pelo

SIBi - Sistema Integrado de Bibliotecas / UNITAU

Revista Ambiente \& Água - An Interdisciplinary Journal of Applied Science / Instituto de Pesquisas Ambientais em Bacias Hidrográficas. Taubaté. v. 2, n. 1 (2006) Taubaté: IPABHi, 2007.

Quadrimestral

ISSN 1980-993X

1. Ciências ambientais. 2. Recursos hídricos. I. Instituto de Pesquisas Ambientais em Bacias Hidrográficas. III. Título.

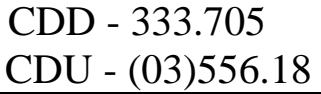




\section{ÍNDICE}

\section{CAPA}

Cobertura do solo e mudanças recentes na cobertura do solo indicando perdas na floresta (desflorestamento), assim como, na floresta secundária no Estado do Mato Grosso, Brasil, no período de 2003 a 2006.

Fonte: MORTON, D.C.; SHIMABUKURO, Y. E.; RUDORFF, B. F. T.; LIMA, A. ; FREITAS, R. M.; DEFRIES, R. S. Conservation challenge at the agricultural frontier: deforestation, fire, and land use dynamics in Mato Grosso. Ambi-Agua, Taubaté, v. 2, n. 1, p. 5-20, 2007. (doi:10.4136/ambiagua.16)

\section{EDITORIAL}

Retrospectiva e perspectiva da Ambiente e Água após um ano de publicação (doi:10.4136/ambi-agua.15)

Getulio Teixeira Batista

\section{ARTIGOS}

Conservation challenge at the agricultural frontier: deforestation, fire, and land use dynamics in mato grosso (doi:10.4136/ambi-agua.16)

Douglas C. Morton; Yosio E. Shimabukuro; Bernardo F. T. Rudorff; Andre Lima; Ramon M. Freitas; Ruth S. DeFries

Spatial and temporal characterization of some water quality physical parameters and their relationships with land-use in Água Fria watershed (Palmas - TO, Brazil) (doi:10.4136/ambi-agua.17)

Alexandre Marco Silva; Harry Edmar Schulz

Mapeamento das Áreas de Preservação Permanente (APP) do município de Santo Antônio do Pinhal, SP: um subsídio à preservação ambiental (doi:10.4136/ambi-agua.18)

Celso de Souza Catelani; Getulio Teixeira Batista

Escoamento superficial na bacia hidrográfica do Ribeirão Itaim 44 (doi:10.4136/ambi-agua.19)

Luiz Sérgio Gonçalves Aguiar; Marcelo dos Santos Targa; Getulio Teixeira Batista

Estimativa da recarga do aqüifero freático na bacia do Rio Una, no município 57 de Taubaté, SP (doi:10.4136/ambi-agua.20)

Jair Santoro; Helio Nóbile Diniz; Nathália Torras Correia; Felipe Rodrigues

Carbone; Luciana Campos de Oliveira Sciotta

Avaliação da precipitação efetiva de um fragmento de Mata Atlântica em diferentes estágios de regeneração no município de Viçosa, MG (doi:10.4136/ambi-agua.21)

Rafael Figueiredo Alves; Herly Carlos Teixeira Dias; José Carlos de Oliveira Júnior; Franklin Nicolai Mota Garcia 


ISSN = 1980-993X - doi:10.4136/1980-993X
www.agro.unitau.br/ambi-agua
E-mail: ambi-agua@agro.unitau.br
Tel.: (12) 3625-4116

\section{Retrospective and perspective of Ambiente e Água after one year of publication \\ (doi:10.4136/ambi-agua.15)}

\section{Getulio Teixeira Batista}

Professor at the Master Degree Program in Environmental Sciences of the University of Taubaté. Estrada Municipal Dr. José Luiz Cembranelli, 5.000; Bairro Itaim; 12.081-010 - Taubaté, SP E-mail: ambi-agua@agro.unitau.br.

\section{RETROSPECTIVE}

After the completion of one year of publication of Ambiente e Água - An Interdisciplinary Journal of Applied Science, the following remarks can be made: three issues were published, totaling 18 articles that involved 68 authors; in addition to three editorials. The articles have come from 24 different institutions from Brazil and abroad. Some of those authors published more than one article. Most of the articles were in Portuguese (60\%), others in English (34\%) and in Spanish (6\%).

Both environmental and water resource themes appeared equally important as the main topic in nine articles each. Five articles covered both themes, simultaneously.

The articles involved local studies (hydrogeology, aquifer recharge) as well as modeling large geographic areas (eight articles) that included the whole Brazilian territory (hydrology modeling), part of the Caribbean region (sea surface temperature and lobster catching), Amazonian Region with four articles (modeling water quality and deforestation), NorthCentral region of Brazil (conservation areas, burning and deforestation), and the Brazilian Southhern region (soybean yield and climatic modeling and forest modeling). Two articles focused on watersheds (physiographic parameters and modeling). One of the articles dealt with permanent preservation areas (PPA) mapping of a municipal district. Another article developed methodology for image analysis that can be used for environmental or water studies.

The main indicator of the scientific community's support was the large number of voluntary peer reviewer's applications. On this first year of publication of Ambi-Água, the list of reviewers included a large number of scientists as can be verified in Table 1 . The journal currently counts with a peer review panel of broad geographic representation and scientific background, even though the great majority is concentrated in the Brazilian Southeastern region, perhaps reflecting the geographic location of the journal.

\section{PERSPECTIVES}

As the journal becomes known by the scientific community at large, it is expected that the number of submissions will increase substantially, especially from abroad. The Editorial Board of Ambi-Água will spread the word about the journal to the Spanish and English speaking communities to increase their participation. The next activities of the Editorial Board will concentrate on seeking broader indexation of the journal to expand the visibility of the articles and seek a positive evaluation by the Qualis/CAPES journal classification system. To reach that goal the Editors will follow Piva et al. (2002) and Ohira et al. (2000) recommendations to overcome the challenges of setting up a new scientific journal. Thus, an increase in the number of published articles in English and Spanish by Ambi-Água is expected to increase the interest in this journal by the international scientific community. 
Table 1. Peer Reviewers of Ambi-Água.

\begin{tabular}{|c|c|c|c|c|}
\hline \multirow{6}{*}{ International } & \multicolumn{3}{|c|}{ Country } & $\mathbf{N}^{\mathbf{o}}$ \\
\hline & \multicolumn{3}{|c|}{ Bolivia } & 1 \\
\hline & \multicolumn{3}{|c|}{ Canada } & 1 \\
\hline & \multicolumn{3}{|c|}{ Spain } & 1 \\
\hline & \multicolumn{3}{|c|}{ United States } & 3 \\
\hline & \multicolumn{3}{|c|}{ United Kingdom } & 1 \\
\hline \multirow{19}{*}{ National } & Region & $\mathbf{N}^{\mathbf{0}}$ & State & $\mathbf{N}^{\mathbf{0}}$ \\
\hline & \multirow{3}{*}{ Center-West } & \multirow{3}{*}{11} & DF & 6 \\
\hline & & & GO & 2 \\
\hline & & & MS & 3 \\
\hline & \multirow{6}{*}{ Northeast } & \multirow{6}{*}{33} & BA & 2 \\
\hline & & & $\mathrm{CE}$ & 7 \\
\hline & & & PB & 12 \\
\hline & & & $\mathrm{PE}$ & 7 \\
\hline & & & RN & 2 \\
\hline & & & SE & 3 \\
\hline & \multirow{3}{*}{ North } & \multirow{3}{*}{14} & AM & 3 \\
\hline & & & PA & 8 \\
\hline & & & TO & 3 \\
\hline & \multirow{3}{*}{ Southeast } & \multirow{3}{*}{167} & MG & 15 \\
\hline & & & RJ & 24 \\
\hline & & & SP & 127 \\
\hline & \multirow{3}{*}{ South } & \multirow{3}{*}{40} & PR & 11 \\
\hline & & & RS & 20 \\
\hline & & & SC & 9 \\
\hline
\end{tabular}

\section{FINAL REMARKS}

The first year of a scientific journal that intends to become a reference for quality in its thematic area is very challenging. The lack of history and the absence of indexation subscription limit the number of submissions even if it has been thoroughly announced. Only authors that relate to and trust the editorial board scientific reputation demonstrate confidence in the future of the journal. Therefore, it is anticipated that in the next year of publication, a large number of qualified articles will be submitted. As the journal becomes evaluated by impact and visibility indices, the journal will receive higher recognition and become more commonly considered for article submission. Therefore, registering the journal in new indexation systems is a goal of the Editorial Board of Ambi-Água for the near future.

\section{REFERENCES}

OHIRA, M. L. B.; SOMBRIO, M. L. L. N.; PRADO, N. S. Periódicos brasileiros especializados em biblioteconomia e ciência da informação: evolução. Enc. Bibli: R. Bibliotecon. Ci. Inf., Florianópolis, n. 10, out. 2000. http://www.encontrosbibli.ufsc.br/Edicao_10/lurdinha.htm. Acesso em 20 junho 2007.

PIVA, J. P.; GARCIA, P. C.; BLANK, D. et al. The challenges and the consolidation of a scientific journal. J. Pediatr (Rio J.), ene./feb. 2002, v.78, n.1, p.01-02. ISSN 00217557. 


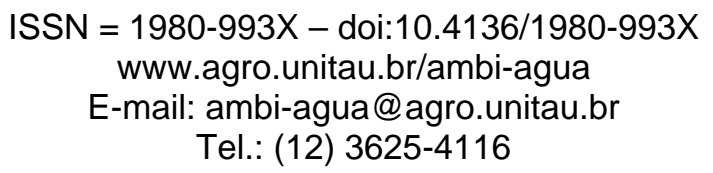

\title{
Conservation challenge at the agricultural frontier: deforestation, fire, and land use dynamics in Mato Grosso \\ (doi:10.4136/ambi-agua.16)
}

\author{
Douglas C. Morton ${ }^{1}$; Yosio E. Shimabukuro²; Bernardo F. T. Rudorff ${ }^{2}$; Andre \\ Lima $^{2}$; Ramon M. Freitas ${ }^{2}$; Ruth S. DeFries ${ }^{1}$ \\ ${ }^{1}$ University of Maryland, Department of Geography, 2181 LeFrak Hall, College Park, MD 20742, USA. \\ E-mail: morton@geog.umd.edu, rdefries@mail.umd.edu \\ ${ }^{2}$ Instituto Nacional de Pesquisas Espaciais, Divisão de Sensoriamento Remoto \\ E-mail: \{yosio, bernardo, andre, ramon\}@dsr.inpe.br
}

\begin{abstract}
Achieving conservation objectives within the rapidly changing agricultural frontier in Mato Grosso State requires tradeoffs between production and preservation. We provide a description of deforestation, fire, and land use dynamics during 2000-2005 to consider a range of strategies for conservation planning. Long-term conservation of Cerrado, transition forest, and Amazon biomes in the state can benefit from direct consideration of landscape structure, duration of post-clearing land use, and the mosaic of land uses surrounding potential conservation corridors or reserve areas. Although the creation of new protected areas may not be feasible, since few large, uninterrupted forest areas exist within the state, some conservation objectives can be met through greater coordination of the legal reserve system among property owners. We present three examples of landscape-level prioritization based on existing Forest Code regulations stipulating $80 \%$ forest reserves on private property. Through a state-mediated system, property owners could augment existing reserve areas on their property through purchase of lands in: 1) buffers surrounding existing conservation units and indigenous reserves; 2) small watersheds with little or no deforestation; 3) forest patches with high connectivity within specified mosaics of different land uses. Any final approach for property-level coordination will depend on the specific conservation goals (e.g., river corridors, bird habitat, or plant biodiversity), but we provide a framework for developing and implementing a conservation plan at the agricultural frontier. Tradeoffs in both conservation value and productive use are required to achieve coordinated conservation at scale.
\end{abstract}

Keywords: Brazilian Amazon; change detection; MODIS; protected areas; conservation strategy.

\section{Desafios para conservação nas áreas de fronteiras agrícolas: desflorestamento, fogo e dinâmica do uso da terra no Mato Grosso}

\section{RESUMO}

Para atingir os objetivos de conservação em áreas de rápida mudança na fronteira agrícola do Estado do Mato Grosso é requerido um balanço entre produção e preservação. Nós apresentamos uma descrição de desflorestamento, fogo e dinâmica do uso da terra no período 2000 - 2005 para definir estratégias para o planejamento de conservação. A conservação a longo prazo das áreas de Cerrado, floresta de transição e do bioma amazônico no Estado pode se beneficiar diretamente das informações sobre a estrutura da paisagem, a 
duração do uso da terra após o corte, e o mosaico de uso da terra nos arredores de potenciais corredores de conservação e áreas de reservas. Embora a criação de novas áreas protegidas pode não ser viáveis, devido a existência de poucas grandes áreas contínuas de florestas dentro do Estado, alguns objetivos de conservação podem ser alcançados através da melhor coordenação do sistema de reserva legal entre os proprietários. Apresentamos três exemplos de priorização a nível de paisagem baseado nas normas do Código Florestal que estipula 80\% de reserva florestal em propriedades particulares. Através de um sistema gerenciado pelo Estado, os proprietários poderiam aumentar as áreas de reservas existentes em suas propriedades através da compra de terra em: 1) buffers nos arredores das unidades de conservação e reservas indígenas existentes; 2) pequenas bacias hidrográficas com pouca ou nenhuma área desflorestada; 3) conexão entre fragmentos de floresta existentes para conectividade da paisagem dentro de mosaico específico de diferentes usos da terra. Qualquer abordagem final para coordenação a nível de propriedade dependerá da finalidade especifica de conservação (e.g., margem de rios, habitat de aves, ou biodiversidade da flora), mas apresentamos um esquema para desenvolver e implementar um plano de conservação na fronteira agrícola. Um balanço dos valores de conservação e uso produtivo são requeridos para atingir uma conservação coordenada.

Palavras-chave: Amazônia Brasileira; detecção de mudança; MODIS; áreas protegidas; estratégia de conservação.

\section{INTRODUCTION}

Protected areas are a central component of worldwide efforts for biodiversity conservation, although debate continues over the role of people in parks and successful conservation (Schwartzman et al., 2000; Terborgh, 2000). In the Brazilian Amazon, both formal state and national protected areas, including parks, biological reserves, and sustainable use areas, and indigenous reserves have been effective in deterring deforestation and fire within their boundaries (Nepstad et al., 2006). One strategy to promote additional conservation of tropical forest through decreased deforestation, therefore, would be to create new protected areas as part of a comprehensive strategy for sustainable use of tropical forests.

Creation of new protected areas and declining rates of deforestation in 2005 and 2006 in the Brazilian Amazon can both be considered conservation successes. New parks and sustainable use areas created since 2002 under the auspices of the ARPA program have added $193,000 \mathrm{~km}^{2}$ of tropical forest to the existing 1,700,000 $\mathrm{km}^{2}$ of parks, sustainable use areas, national forests, and indigenous reserves within the Brazilian Amazon (Brasil, 2003). At the agricultural frontier, annual deforestation declined from more than 27,000 $\mathrm{km}^{2}$ in 2004 to $18,800 \mathrm{~km}^{2}$ in 2005 , and a further reduction is anticipated based on preliminary data analyses from 2006 (INPE, 2007).

However, this reduction in deforestation is unrelated to the push for new protected areas, since major reserve creation focused on areas far from the arc of deforestation. The decrease in deforestation is more likely attributable to state level property registration programs (Fearnside; Barbosa, 2004); increased satellite-based enforcement targeting illegal deforestation, such as DETER (Anderson et al., 2005; Shimabukuro et al., 2005); and declining prices for soybeans and other agricultural commodities (Morton et al., 2006). One notable exception is the mosaic of new biological reserves and national forests in the Terra do Meio region and bordering the federal highway BR-163 in central Pará State (Campos; Nepstad, 2006). These reserves were specifically designed to influence future development 
along important transportation corridors in anticipation of increased deforestation pressure from the paving of federal highways in coming years (Soares Filho et al., 2006).

The lack of protected areas at the current agricultural frontier presents two important questions. Are new protected areas in regions of rapid land cover change possible, practical, or desirable, given the tradeoffs between production and preservation that would be necessary to achieve conservation objectives? Or, are other strategies more viable to achieve specific conservation goals? We consider the case of Mato Grosso State to illustrate the opportunities and constraints of conservation planning at the agricultural frontier (Figure 1).

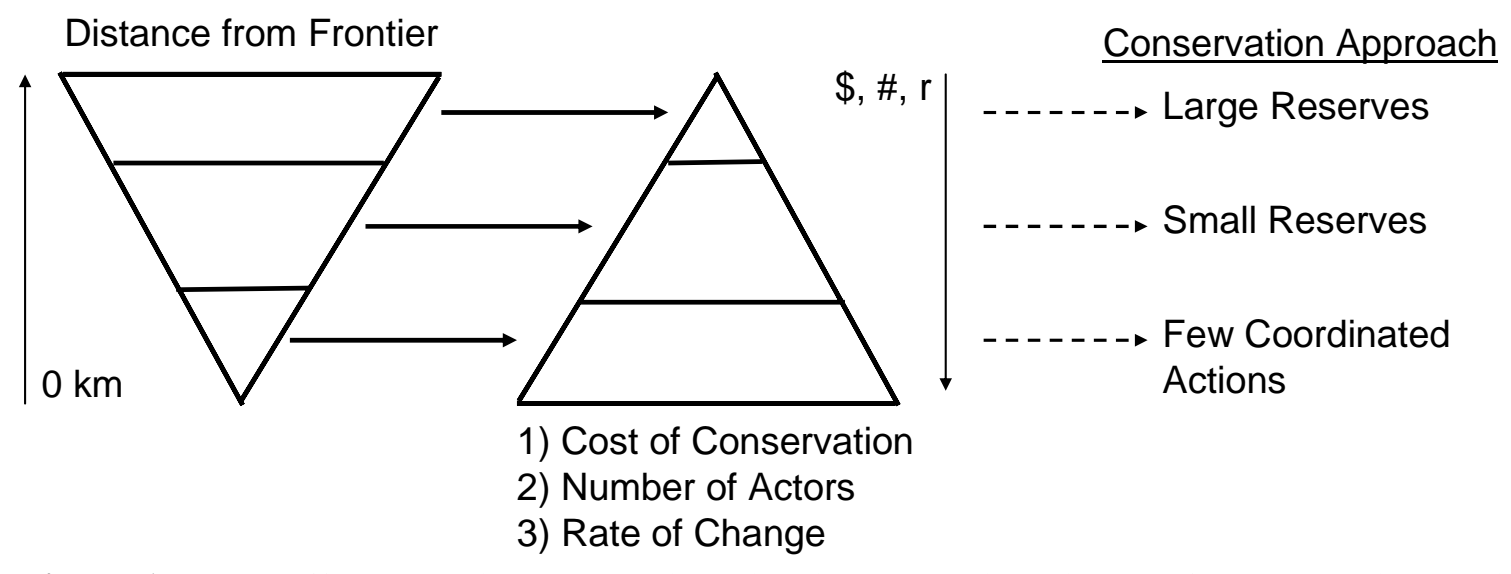

Figure 1. Tradeoffs present in conservation planning at varying distance from the agricultural frontier. The complexity of conservation action increases exponentially as the area in question becomes closer to the existing frontier, measured in terms of cost, time, number of actors, or other similar variables. Historically, these higher costs of conservation along the frontier have limited conservation action in favor of forest conversion for other uses.

Mato Grosso State is the most active land use change frontier in the Brazilian Amazon in terms of total forest loss (INPE, 2007). The mosaic of land uses on existing cleared areas adds pressure for more forest loss, creating a complicated environment in which to achieve conservation objectives because of the myriad actors and rapid rate of change. However, four scientific and practical rationales exist for promoting conservation along the existing agricultural frontier. First, Mato Grosso contains most of the dry forest ecoregion (WWF, 2004) in the southern Amazon (Figure 2). The dry forest, also referred to as transition forests given their ecotonal location between Cerrado vegetation in the south and more moist tropical forests to the north, is the most affected biome from recent land cover changes, yet least protected. At present, six small conservation units encompass less than $2 \%$ of the ecoregion within Mato Grosso, although the Xingu Indigenous Reserve does include this forest type. Second, forest dieback as a result of climate change in the central Amazon Basin (Oyama; Nobre, 2003; Cox et al., 2004) may relegate forests at the current agricultural frontier zone as climatic refugia for tropical forests in the future. Third, existing legal framework in the Brazilian Forest Code provides a mechanism for coordinating property-level conservation in legal reserves. These opportunities have not been realized at scale given the difficulty in designing and implementing a coordinated scheme for property development. Finally, present opportunities for conservation are rapidly diminishing, and restoration of degraded forests and abandoned agricultural land is often more expensive than initial preservation. 


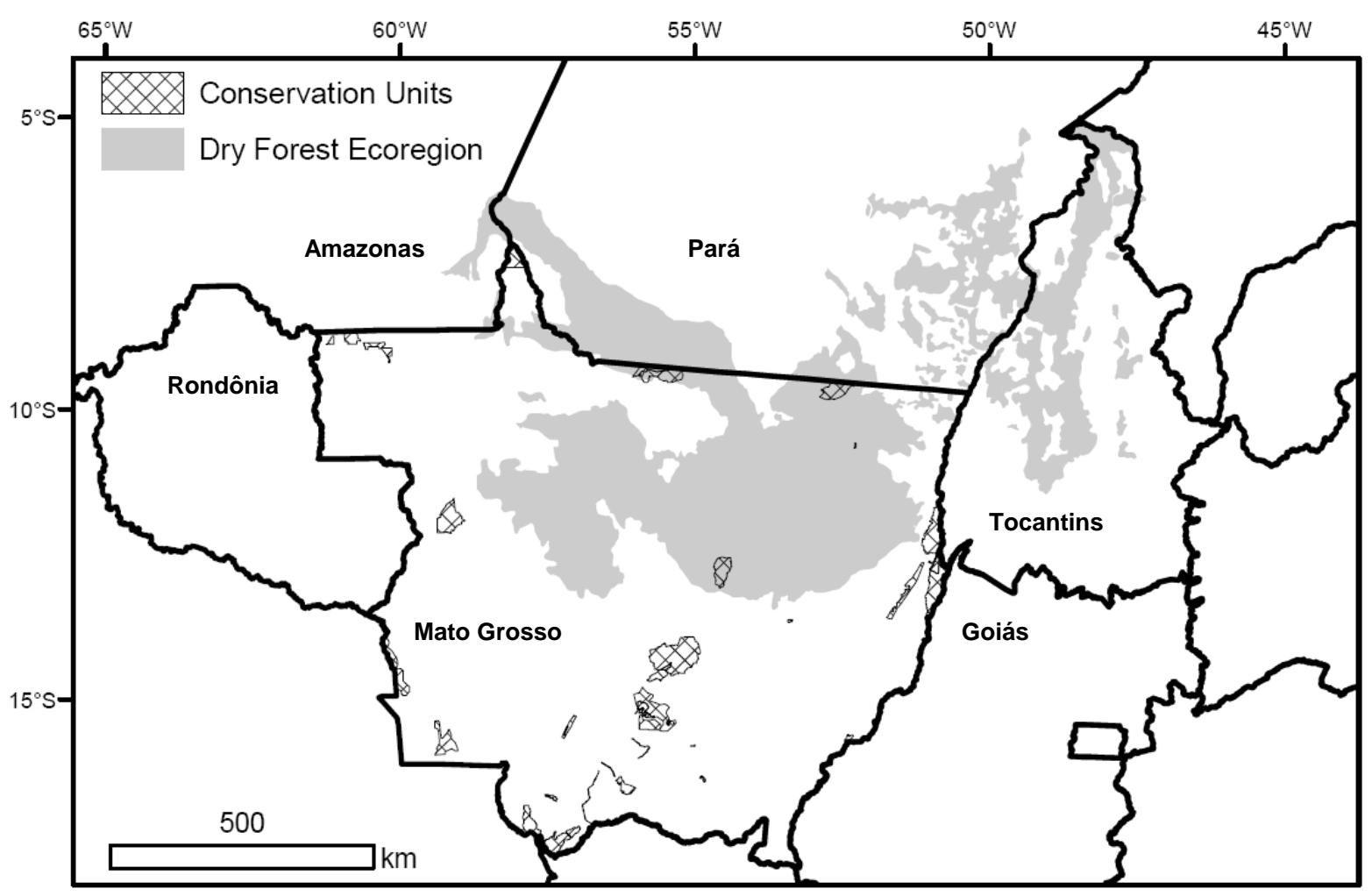

Figure 2. The dry forest ecoregion in relation to state boundaries within the Brazilian Amazon. Existing conservation units in Mato Grosso state have limited coverage of this unique biome.

We consider the context for developing forest conservation strategies in Mato Grosso based on remote sensing data on land cover and land use change. Remote sensing analyses provide a wealth of information about landscape properties, rates of change, and available regions for implementing different conservation approaches such as corridors, reserves, or local-scale coordination among landowners. The goal of this paper is to combine various perspectives on recent changes in Mato Grosso to examine the opportunities and challenges for effective conservation planning at the agricultural frontier.

\section{MATERIAL AND METHODS}

To access land cover and land use dynamics, we combine data from a variety of recent studies to analyze the available information from satellite remote sensing for conservation planning (Figure 3). A land cover classification from 2002 (Anderson et al., 2005) was updated to include land cover changes through 2004 (Lima et al., 2007) and forest losses from the INPE PRODES program through August, 2006 (INPE, 2007). In addition, we incorporate spatial detail for the conversion of secondary forest and Cerradão within Mato Grosso during this period (Morton et al., 2007). The distribution of post-clearing land uses is also critical for conservation planning, since habitat quality, species dispersal, and potential impacts of agrotoxins or livestock waste depend on the matrix of nonforest land cover within a given watershed or region. Morton et al. (2006) provide the first estimate of land use following recent deforestation (2001-2004); we provide updated information including analysis of 2005 deforestation.

Fires used for land clearing and management influence the conservation potential of neighboring forest vegetation. We analyze active fire detections from the Moderate Resolution Imaging Spectroradiometer (MODIS), two NASA satellites that provide daily 
coverage of the entire Amazon Basin, and burn scar maps derived from MODIS imagery in 2005 to assess the influence of fire activity on existing, planned, and possible additional conservation areas. The burn scar map was produced using MODIS (MOD09) data acquired in 2005 following the methodology presented by Anderson et al. (2005). Burn scars were identified using the shade fraction image derived from a Linear Spectral Mixing Model (Shimabukuro; Smith, 1991), similar to the PRODES and DETER methodology (Shimabukuro et al., 2005).

Finally, we identify regions with high potential for future conservation action, using metrics of landscape structure for fragmentation and isolation. We follow a framework outlined by Lima (2005) to describe conservation opportunities in Mato Grosso. Existing conservation units are considered in terms of biome representation, overall area, and degree of encroachment by other land uses (e.g., pasture, cropland) and fire. We also consider the role of indigenous areas in these aspects to assess the effectiveness of formal and informal conservation areas. Possible conservation corridors are considered in the context of representation of unique biomes within the state, size of potential reserve area, and neighboring land uses to illustrate tradeoffs involved with conservation planning at the rapidly changing agricultural frontier. Small watershed areas included in this analysis were derived from the United States Geological Survey topographic map at 30 arc second resolution (GTOPO30).

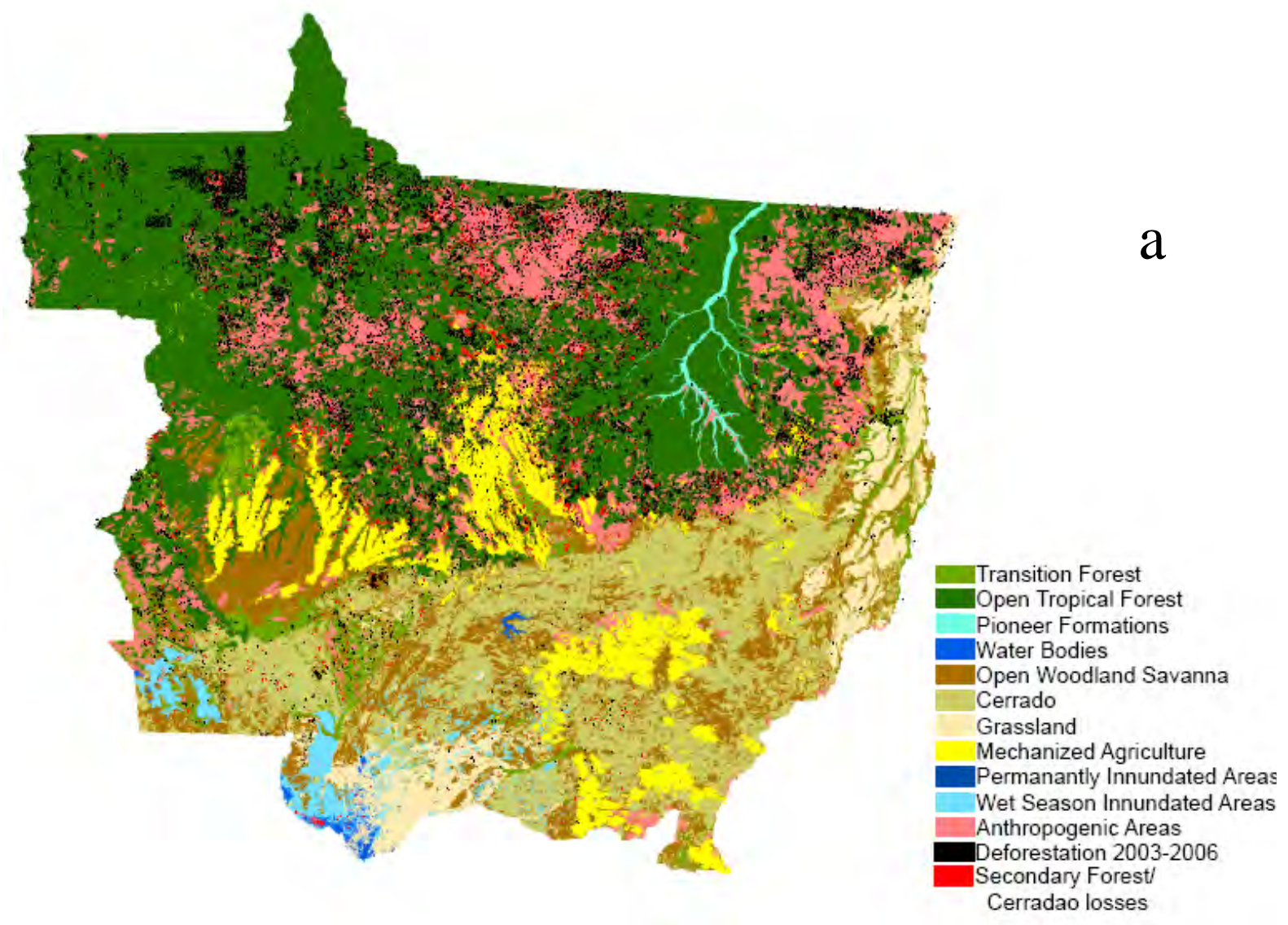


MORTON, D.C.; SHIMABUKURO, Y. E.; RUDORFF, B. F. T.; LIMA, A.; FREITAS, R. M.; DEFRIES, R. S. Conservation challenge at the agricultural frontier: deforestation, fire, and land use dynamics in Mato Grosso. Ambi-Agua, Taubaté, v. 2, n. 1, p. 5-20, 2007. (doi:10.4136/ambi-agua.16)
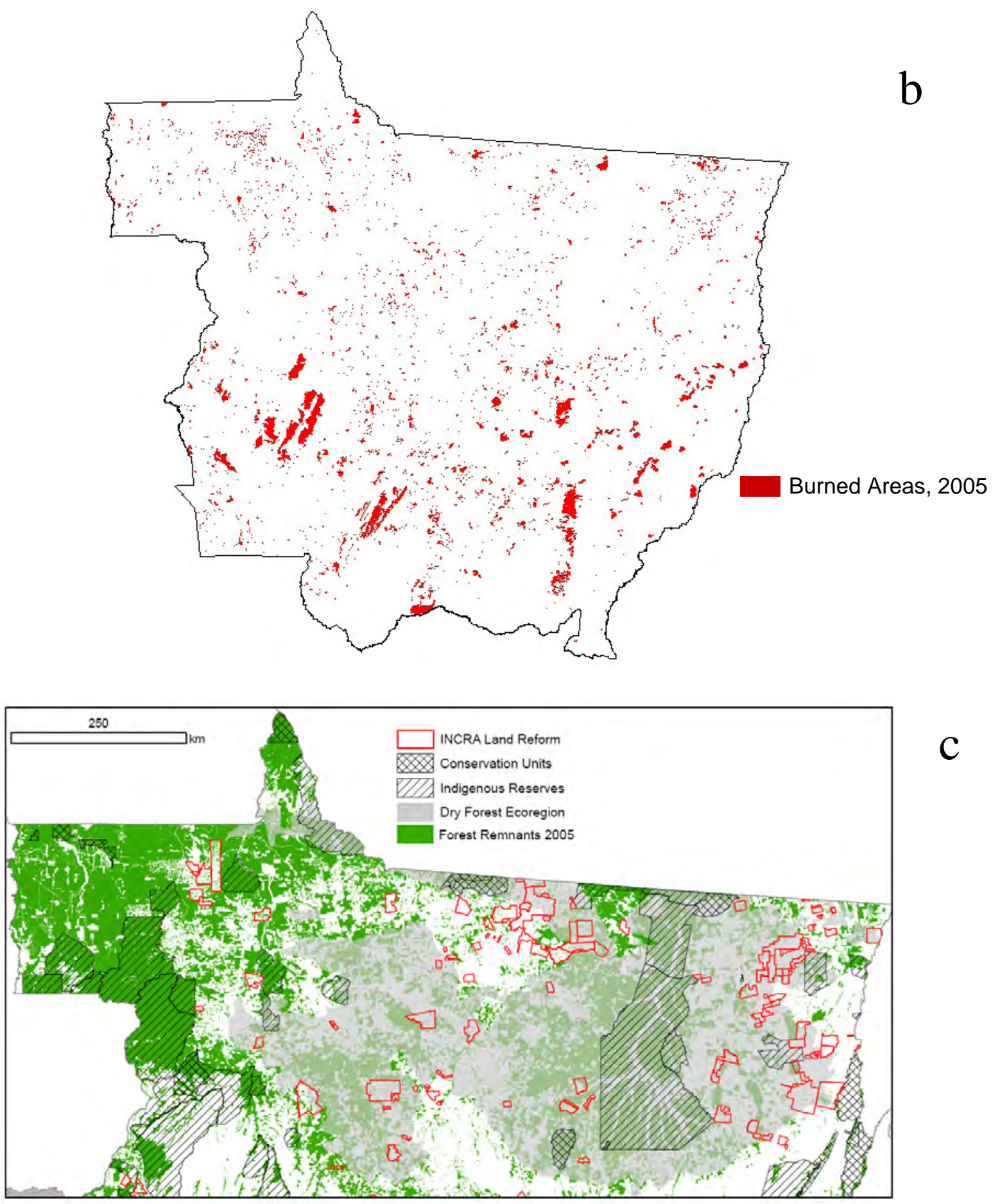

Figure 3. Statewide land cover and recent land cover changes, highlighting deforestation and secondary forest losses during 2003-2006 (a). Fire is also a critical seasonal component of the landscape that influences conservation actions (b). The forest conservation context, relative to ecoregion boundaries, remaining forest fragments, and existing conservation units and indigenous reserves (c) summarizes the challenges for designing and implementing a conservation strategy at the agricultural frontier. 


\section{RESULTS AND DISCUSSION}

\subsection{Land Use and Land Cover Change Context}

Mato Grosso State contains a variety of important biomes for conservation and productive regions for cropland agriculture and cattle ranching. Figure 3 shows the division of forested and nonforest land cover types roughly split between the north and south, respectively. We focus on the forested region to illustrate the complexity of possible future conservation scenarios, although a similar analysis could be done for Cerrado or Pantanal wetland ecosystems. Within the forested region, two important patterns of development exist. First, within the Xingu River watershed, recent deforestation pressure has advanced nearly to the boundary with the Xingu Indigenous Reserve, led by the advance of soybean and other crops (Figure 4). Second, the central development corridor that follows the Cuiabá-Santarém highway (BR-163) has almost completely separated forested regions east and west of the road.

Recent forest loss in Mato Grosso has been rapid, although estimated deforestation in both 2005 and 2006 show reductions from the peak clearing activity in 2002-2004 (Table 1). In addition to losses of tropical forest, the state also had net losses of secondary forest on previously cleared areas (Morton et al., 2007). Rapid turnover of regrowing forest provides an additional indication of the permanence of forest losses in the state. Net loss of secondary forest, where the rate of secondary forest clearing exceeds that of land abandonment to forest regeneration, suggests that the landscape does not include a variety of forest habitats in different age classes. Finally, losses of tall, closed-canopy Cerradão vegetation mirrored rates

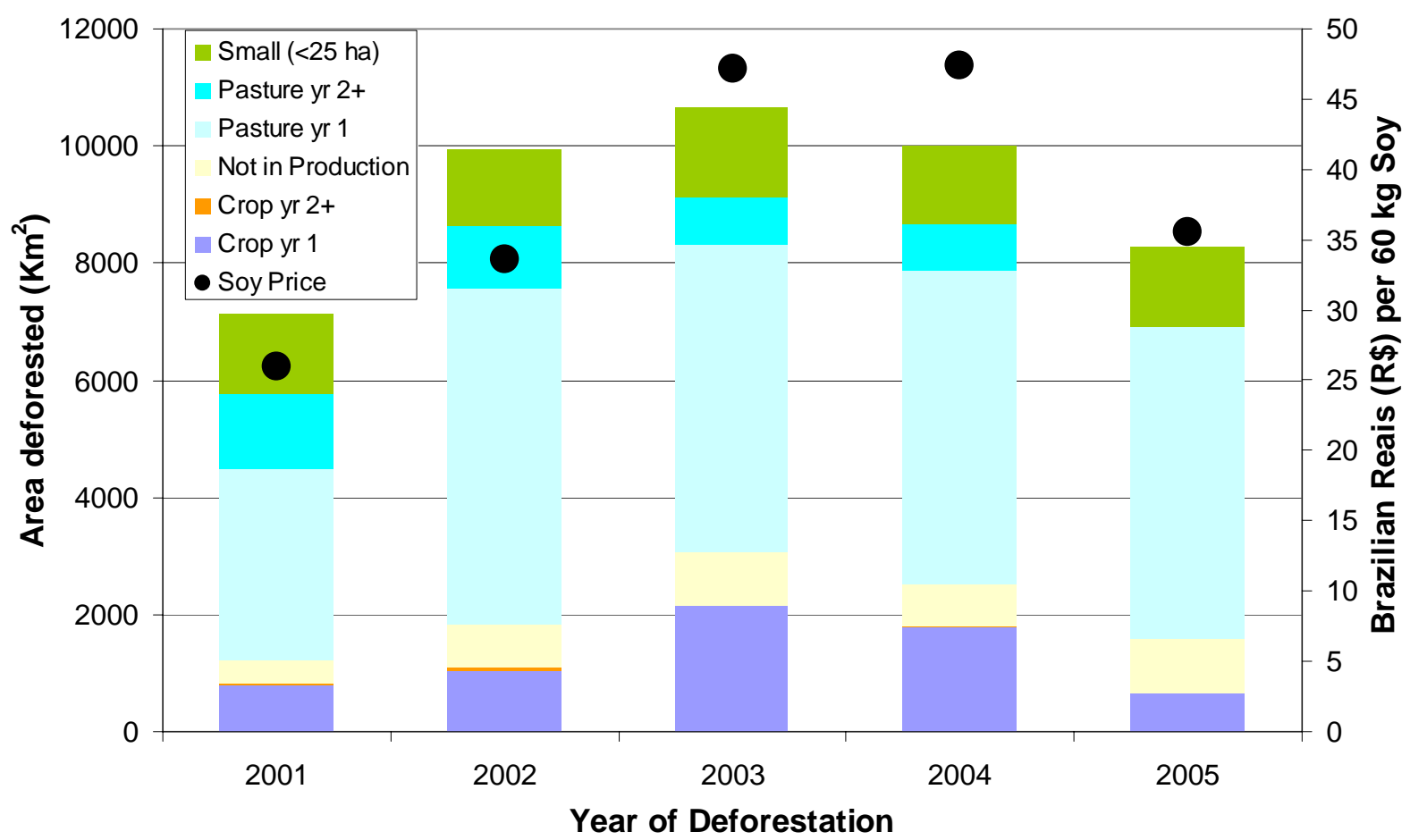

Figure 4. Post-clearing land use for 2001-2005 deforestation in Mato Grosso State based on MODIS phenology data from 2002-2006, following methods outlined in Morton et al., (2006). The amount of forest cleared directly for cropland expansion is related to inflation-adjusted soybean prices. Inter-annual variability in deforestation dynamics illustrates the roles of different actors (soybean growers, ranchers, smallholders) in potential conservation action. 
Table 1. Estimated deforestation, net loss of secondary forest cover, and Cerradão conversion for 2002-2006. Deforestation estimates are derived from PRODES digital data (INPE, 2007); Morton et al. (2007) provide secondary forest and Cerradão loss estimates.

\begin{tabular}{lrrrrr}
\hline & $\mathbf{2 0 0 2}$ & \multicolumn{1}{c}{$\mathbf{2 0 0 3}$} & $\mathbf{2 0 0 4}$ & $\mathbf{2 0 0 5}$ & $\mathbf{2 0 0 6}$ \\
\hline Deforestation & 10.036 & 10.773 & 10.245 & 8.480 & $4.438^{\star}$ \\
Net Secondary & 235 & 651 & 683 & & \\
Forest Loss & 398 & 640 & 613 & 250 & \\
Cerradão Loss & 398 & \\
\hline
\end{tabular}

* Based on the analysis of 24 Landsat scenes in Mato Grosso, including both deforestation and residual classes.

of forest clearing in 2002-2005. As shown in Figure 3a, these open woodland regions are found in very few locations along the forest-Cerrado transition; rapid rates of clearing in Cerradão therefore provide a rationale for conservation of remaining fragments of this unique species assemblage.

Fire use for land clearing and maintenance of fire-dependent land uses, such as pasture, introduces a second complication for conservation at the forest frontier. Figure 3b shows the statewide extent of burning during 2005, including evidence for understory fires within remaining forest fragments. Forest damage from understory fires can lead to a positive feedback cycle, whereby initial burning opens the canopy, drying fuel loads from fire-killed vegetation, making future fires more likely (Cochrane et al., 1999). Whether land use surrounding existing protected areas or possible future conservation zones require fire use is an important consideration for conservation planning.

The land cover and land use change context in Mato Grosso forms the basis of any plans for future conservation action. Figure 4 shows the variety of actors and an example of the role of market forces that influence current trends in deforestation. Conservation options must be balanced with the statewide interest in sustainable agricultural production, and farmers and cattle ranchers are likely to bring unique demands to the discussion of conservation goals. Recent action by ABIOVE, an industry group representing soybean producers, in response to a European boycott of soybeans from the Amazon suggests that farmer-led conservation initiatives are both desirable and imminent (ABIOVE, 2006). Similar interest may exist within the ranching community as a means to certify beef production in terms of both management and safety (Nepstad et al., 2006). Figure 3c provides an overview of the landscape-level situation for forest conservation in Mato Grosso. Few large forest fragments remain east of the Xingu Indigenous Reserve. East-west connectivity among forest patches is also restricted. However, large forest areas remain in the western Xingu Basin, in addition to potential buffer zones around indigenous reserves in northwest Mato Grosso.

\subsection{Existing and Planned Conservation Units}

According to data from FEMA (2006), the state of Mato Grosso has 43 conservation units, 5 of which are federally protected areas and the remaining 38 are under state control. The majority of the conservation units (35) have protected status (Proteção Integral). The remaining 8 conservation units are considered sustainable use areas. In all, these conservation units protect 2,887,481 hectares (ha), or roughly $3 \%$ of the state's land area. This level of protection is well below the threshold of $10 \%$ conservation of the legal Amazon in conservation units set by the national congress. Recent reserve creation in other Amazon 
states through the ARPA program has not yet designated new reserves in Mato Grosso towards this goal.

As a result of the low proportion of the state formally protected in federal and state conservation units, coverage of individual biomes is well below the suggested minimum areas required for biodiversity conservation recommended by Noss and Coperrider (2004). Lima (2005) highlights an additional problem with the current system of protected areas in the state-evidence for anthropogenic land uses within the boundaries of several conservation units, suggesting that current levels of oversight for protected areas has been unable to deter illegal land clearing.

A more important base of conservation of natural ecosystems within Mato Grosso is the network of indigenous reserves within the state. As of April 2004, there were 70 indigenous reserves occupying roughly $12,500,000$ ha, equivalent to $14 \%$ of the land area in Mato Grosso. Although indigenous reserves are not legally required to provide environmental protection of natural ecosystems within their territories, forested indigenous reserves within Mato Grosso have been equivalent or better than formal conservation units at limiting deforestation and fire (Nepstad et al., 2006). Over time, this trend may change. Studies carried out in southern Brazil, where contact between indigenous populations and populations outside of reserves have occurred for much longer periods than in Mato Grosso, suggest that indigenous reserves are inefficient for natural resource protection in older frontier zones (Galetti, 2001). Already in Mato Grosso, the presence of soybean cultivation has been identified within indigenous reserves in the Chapada dos Parecis region (Ribeiro, 2004; Lima, 2005).

As recently as 2004, State zoning documents showed 15 proposed new conservation areas (Mato Grosso, 2004). Of these 15, the 4 slated for full protection all experienced new deforestation in 2005 and 2006 for other non-forest land uses. The remaining 11 proposed conservation units were slated for sustainable use designations, of which 4 experienced deforestation by 2006. Low levels of representation of major biomes within the existing protected area system, combined with recent land cover change trends in existing and planned conservation units, suggest that a new strategy for conservation may be necessary at the agricultural frontier.

\subsection{Landscape Assessment for Conservation Opportunities}

The current landscape context of land cover and land use change provides the opportunity to explore a variety of forest conservation options within the fragmented landscape to identify remnant forest patches that satisfy specific conservation goals. We use forest vegetation as the organizing bases for conservation objectives, but mammal habitat, insect diversity, or the presence of endangered species could also serve as the framework for a statewide conservation strategy. We begin with the premise that large reserve creation is desirable, but no longer practical, given the degree of fragmentation at the forest frontier. Therefore, we focus on the possibility to prioritize smaller areas for state-coordinated investment, possibly as part of a market framework to allow property owners to compensate for missing legal reserve areas on their own properties. Prioritizing these additional areas of conservation interest could be done based on a variety of landscape properties (Figure 5).

The small watershed is a landscape unit that incorporates elements of ecosystem function, and could therefore provide an ecological basis for conservation planning. Figure 5 a shows the small watersheds with more than $80 \%$ forest cover remaining, based on deforestation and land use change statewide through 2005. The numbers are encouraging; 80$89 \%$ forested $\left(\mathrm{n}=153,42,400 \mathrm{~km}^{2}\right), 90-99 \%$ forested $\left(\mathrm{n}=252,63,300 \mathrm{~km}^{2}\right), 100 \%$ forested $\left(\mathrm{n}=47,4,300 \mathrm{~km}^{2}\right)$. The highest concentration of forested watersheds is in northwest Mato 
Grosso, including a number of watersheds that extend into neighboring Rondônia (35), Amazonas (22), and Pará (16) states. Within the dry forest ecoregion, 122 small watersheds remain with high forest cover. Some watersheds are already partially included in protected areas and indigenous reserves; these watersheds might be of highest priority for additional conservation, given the potential down-stream influence of land use change in other portions of these watersheds.

A second framework for prioritizing addition forest protection could be to add conservation value to existing protected areas using a system of buffers (Figure 5b). As noted previously, little connectivity exists between the Xingu Indigenous Reserve and forest fragments on the eastern side. However, connectivity is much higher on the western edge, including potential linkages within $20 \mathrm{~km}$ to established conservation units.

Currently, state highway MT-130 passes between these two areas, nicknamed the "Rodovia da Economia." Balancing proposed development in this corridor with potential conservation goals may require a change of course at the state level. With this type of conservation connectivity becoming increasingly rare at the landscape scale, tradeoffs between conservation and development may become more likely. A similar approach could be used to identify regions with small gaps between large remaining forest fragments as a means for protecting large tracts of forest, regardless of the regularity of the new reserve shape.

A third approach to identifying possible conservation opportunities on the landscape is to examine the matrix of forest cover, including the distance between fragments of varying size, fire-dependence of intervening land uses, and recent rates of deforestation (Figure 5c). This strategy combines concepts from population ecology (minimum viable population), landscape ecology (fragment shape and edge effects), and current land use as a proxy for future fire risk. By maximizing the size of remaining forest fragments, restricting the distance between fragments to $<2 \mathrm{~km}$, and favoring land uses that do not use fire, such as soybean cultivation, the landscape in Figure 5c could be the basis for an integrated production and protection zone with potential conservation value for bird species. The key to implementing this type of conservation strategy is to clearly define the mosaic composition, allowing for restoration or expansion of forest areas within the mosaic to meet these needs, and monitoring the success of such a reserve design over time.

Any scientifically-based approach for additional forest conservation in Mato Grosso is likely to consider the approaches presented here, although other strategies exist. Prioritizing buffer areas around existing protected areas and indigenous reserves can be seen as enhancement; this approach assumes that the initial allocation of lands to protected areas or indigenous reserves was consistent with current conservation goals, or that conservation areas would be more effective if they were larger. The approaches built around intact forested watersheds or landscape mosaics with a concentration of large forest patches are predicated on the need for expansion of existing conservation coverage. In addition to the examples described here, the selection of these areas could also prioritize specific habitat qualities, such as forest or Cerradão on flat terrain, or seek to minimize the influence of a different suite of specific land uses or land cover changes. We provide a summary of the available satellite data with which to develop the landscape context; specific conservation objectives may then be tested against the landscape context to provide the scientific rationale for prioritizing conservation action.

Such a coordinated statewide conservation program will undoubtedly require more active participation from both government and civil society, since the planning process is only the first stage of conservation. Continued pressure for development at the agricultural frontier 
MORTON, D.C.; SHIMABUKURO, Y. E.; RUDORFF, B. F. T.; LIMA, A.; FREITAS, R. M.; DEFRIES, R. S. Conservation challenge at the agricultural frontier: deforestation, fire, and land use dynamics in Mato Grosso. Ambi-Agua, Taubaté, v. 2, n. 1, p. 5-20, 2007. (doi:10.4136/ambi-agua.16)
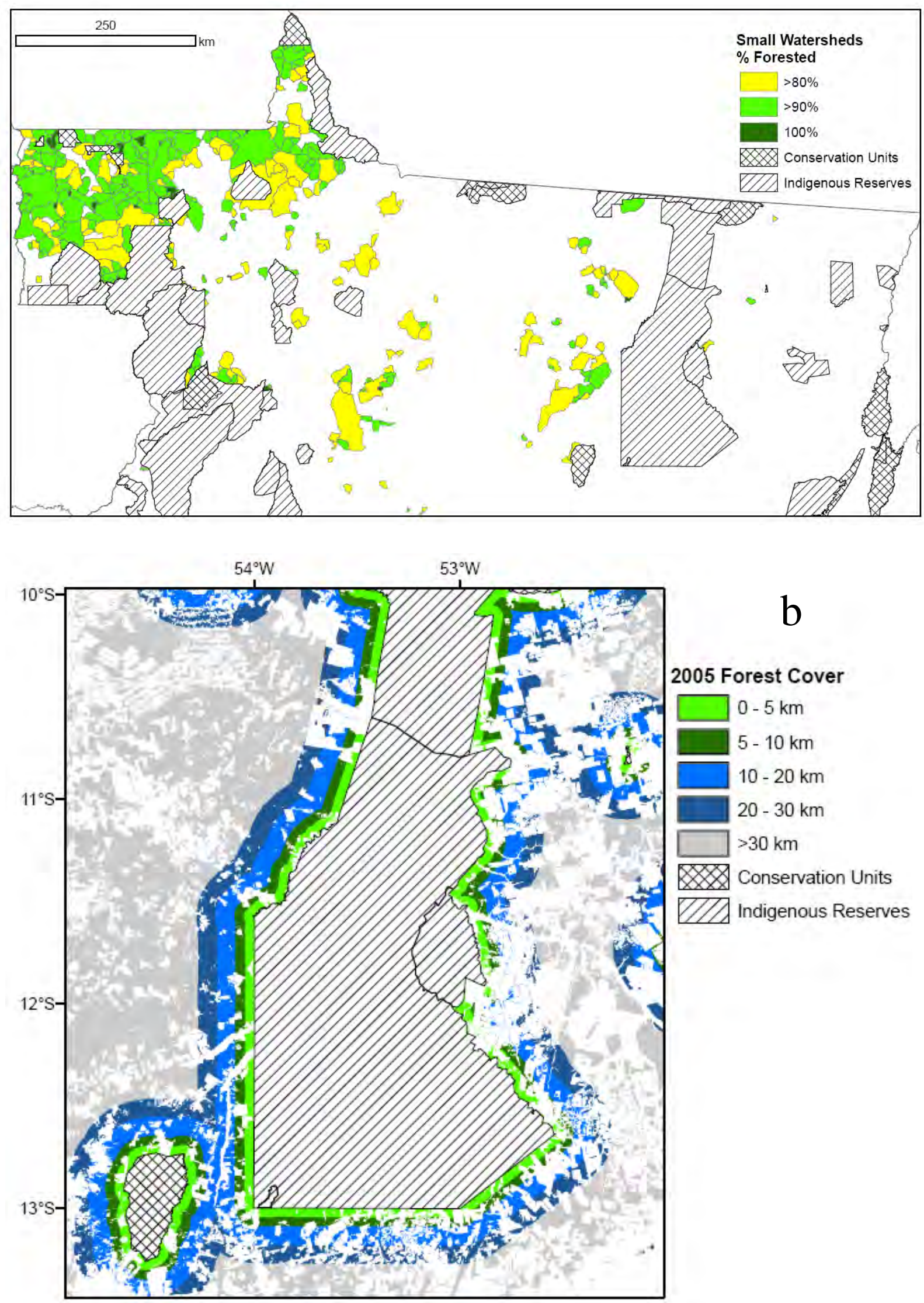

b

2005 Forest Cover

$\square-5 \mathrm{~km}$
$5-10 \mathrm{~km}$
$10-20 \mathrm{~km}$
$20-30 \mathrm{~km}$
$\square 30 \mathrm{~km}$
$\square$ Conservation Units
$\square$ Indigenous Reserves




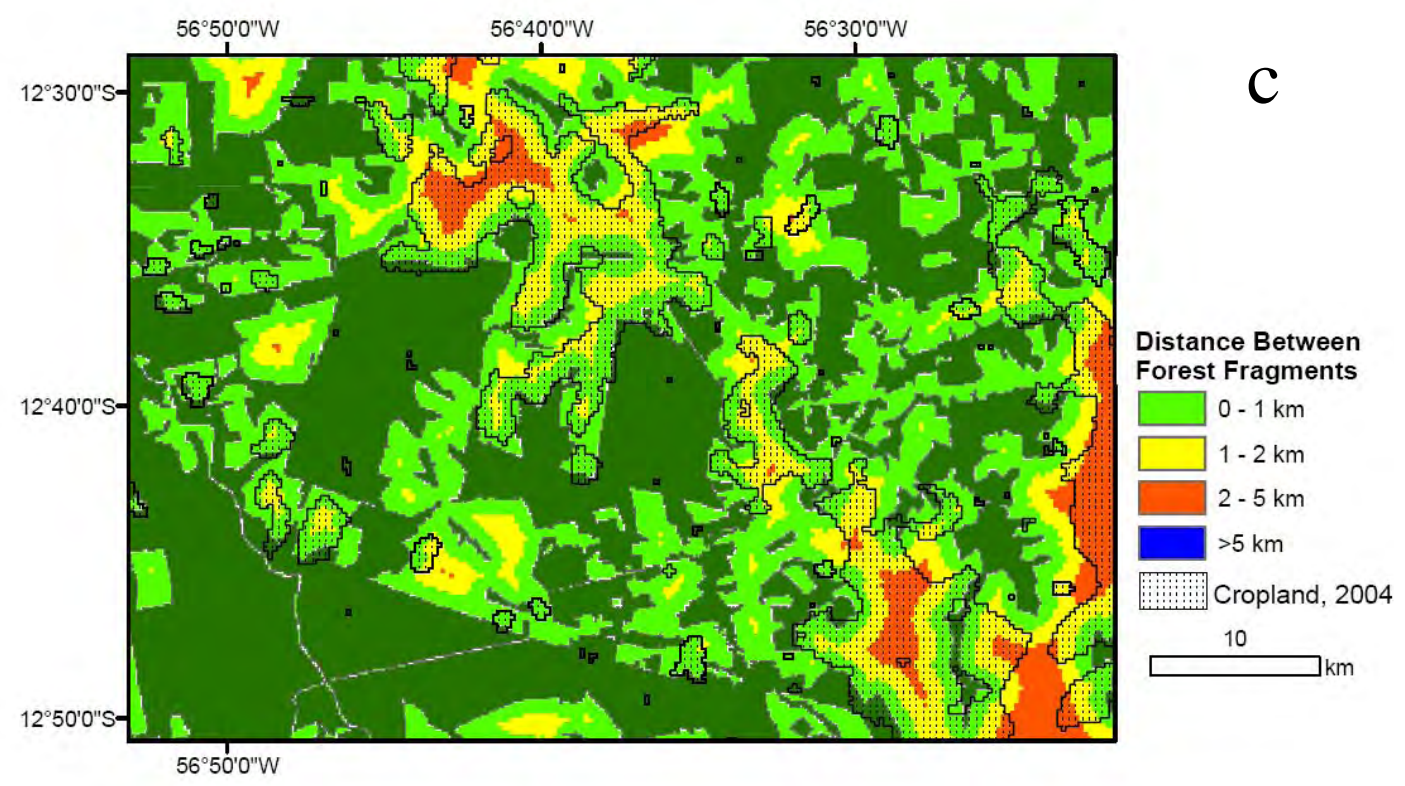

Figure 5. Forest conservation strategies in Mato Grosso based on small watersheds outside of existing conservation units with high percentages of remaining forest cover in 2005 (a), buffer zones surrounding existing conservation units and indigenous reserves (b), and landscape mosaics with large forest patches separated by cropland areas $<2 \mathrm{~km}$ wide (c).

will therefore necessitate both commitment to and enforcement of the conservation plan (Nepstad et al., 2002). The decision to augment existing conservation approaches in the state will require tradeoffs, both in development restrictions and conservation quality. Forest areas near the frontier are likely to have been logged, burned, or hunted-possibly "lower quality" conservation areas than regions with less development pressure. However, we highlight a series of landscapes within the current development context in Mato Grosso where conservation, rather than more costly methods of restoration, is still feasible, albeit with more intensive methods for coordination among conservation units and private landholders. The alternative to increased, coordinated conservation in the near-term is likely to be additional forest fragmentation along the frontier, with remnant forest patches occupying a shrinking mosaic of steep slopes, poor soils, areas far from roads, and small, property-level fragments of natural vegetation as stipulated by the Forest Code.

\subsection{Leverage for Conservation Action}

We have focused on the possibility of a state-led program for purchasing conservation lands as the mechanism for additional conservation within the existing legal framework. Groundwork for such a system is already highly advanced. The majority of private properties in Mato Grosso have already been registered through a state environmental licensing effort, SLAPR (Sistema de licenciamento Ambiental em Propriedades Rurais no estado do Mato Grosso). One environmental non-profit organization, Conservation International, has already developed a localized system for compensation near Parque das Emas in Goiás State when landholders have insufficient legal reserves on their property (Buchanan et al., 2007). A similar system for conservation planning is under development for the entire state of Goiás (Ferreira Junior et al., 2007). Building on these successes in the region, a state-led effort for coordination among private landowners seems promising. 
Additional leverage for conservation action within the state may come from three seemingly different sources. The state receives important revenue from eco-tourism; visitors interested in birding, wildlife viewing, and fishing have a unique opportunity to explore the Pantanal wetlands, Cerrado, and Amazon forest in Mato Grosso. These constituents are likely to favor the creation of more small reserve sites, especially if limited access is allowed for ecotourism purposes. Second, large agribusiness interests realize their market share is directly tied to environmental conditions in the state. A recent boycott of soybeans from the Amazon in Europe has prompted industry action on a number of new conservation and product certification schemes ${ }^{1}$. Third, the nascent ecosystem services sector may soon provide a legal and market framework for new conservation efforts similar to that of the legal reserve system on private property. Recent discussions of "averted deforestation" (Santilli et al., 2005) have introduced the potential for different ecosystem service payments as part of the planning process for post-Kyoto Protocol actions to regulate greenhouse gases. Given the high rates of recent forest loss in Mato Grosso, the state could benefit financially from implementing the SLAPR system for deforestation reduction and conservation planning.

\section{CONCLUSIONS}

Conservation within the matrix of fragmented land cover and continuing deforestation is complex, and may require difficult tradeoffs between production and preservation. Additional complications for conservation planning arise from the narrow time window for new conservation action within any rapidly changing environment. We provide the landscape context of land use and land cover change based on analyses of satellite remote sensing data. Although most conservation units and indigenous reserves are still serving as barriers to deforestation, proposed areas for future reserves have not fared well in recent years. The prospect for new, large conservation units at the agricultural frontier is not promising. However, a variety of conservation opportunities do exist for forest conservation when contributions can be made from both private and public land holdings.

The new property registration system in Mato Grosso, SLAPR, combined with legal requirements for $80 \%$ protection of forest on private property, provides a framework for a statewide system to purchase additional lands for conservation. We highlight several methods for prioritizing areas for conservation, including buffers surrounding existing protected areas, small watersheds with little or no deforestation, and areas that retain high connectivity among large forest remnants. In each case, remote sensing data are essential to develop a coordinated, landscape scale approach. Any final approach for property-level coordination will depend on the specific conservation goals (e.g., river corridors, bird habitat, or plant biodiversity), but we provide a framework for developing and implementing a conservation plan at the agricultural frontier.

\section{ACKNOWLEDGEMENTS}

This research was supported by FAPESP grant (Proc. 2003/01727-0) and by the NASA Large Scale Biosphere-Atmosphere Experiment in Amazônia (LBA-ECO), project LC 22. We would also like to thank an anonymous reviewer for helpful comments on a previous version of this manuscript.

\footnotetext{
${ }^{1}$ Communication provided by Carlos Scaramuzza in São Paulo, October 2006.
} 


\section{REFERENCES}

ASSOCIAÇÃO BRASILEIRA DAS INDÚSTRIAS DE ÓLEOS VEGETAIS. Comunicado, 2006. Disponível em: <http://www.abiove.com.br/informa_br.html>. Acesso em fev. 2007.

ANDERSON, L. O.; ARAGÃO, L. E. O.; LIMA, A.; SHIMABUKURO, Y. E. Detecção de cicatrizes de áreas queimadas baseada no modelo linear de mistura espectral e imagens índice de vegetação utilizando dados multitemporais do sensor MODIS/TERRA no estado do Mato Grosso, Amazônia brasileira. Acta Amazonica, Manaus, v.35, n.4, p.445-456, 2005.

ANDERSON, L. O.; SHIMABUKURO, Y. E.; DeFRIES, R. S.; MORTON, D. C. Assessment of deforestation in near real time over the Brazilian Amazon using multitemporal fraction images derived from Terra MODIS. IEEE Geoscience and Remote Sensing Letters, Piscataway, v. 2, n. 3, p. 315-318, 2005.

ANDERSON, L. O.; SHIMABUKURO, Y. E.; LIMA, A.; MEDEIROS, J. S. Mapeamento da cobertura da terra do Estado do Mato Grosso através da utilização de dados multitemporais do sensor MODIS. Revista Geografia, Londrina, v. 30, p. 365-388, 2005.

BRASIL. Ministério do Meio Ambiente. Plano Amazônia Sustentável. Brasília: Ministério do Meio Ambiente, 2003. 101p.

BUCHANAN, J.; BARROSO, M.; MACHADO, R.; MOREIRA, R.A.; PRADO, P.G.; TELLES, A. Engaging farmers and agribusiness companies to create biodiversity conservation corridors. In: Cerrado land use and conservation: balancing human and ecosystem needs. Washington: Conservation International, 2007. In Press.

CAMPOS, M. T.; NEPSTAD, D. C. Smallholders, the Amazon's new conservationists. Conservation Biology, Oxford, v. 20, n. 5, p. 1553-1556, 2006.

COCHRANE, M., A.; ALENCAR, M.; SCHUlZE, C. M.; SOUZA JR., D. C.; NEPSTAD, P.; LEFEBRE et al. Positive feedbacks in the fire dynamic of closed canopy tropical forests. Science, Washington, v. 284, p. 1832-1835, 1999.

COX, P.; BETTS, R.; COLLINS, M.; HARRIS, P.; HUNTINGFORD, C.; JONES, C. Amazonian forest dieback under climate-carbon cycle projections for the 21st century. Theoretical and Applied Climatology, New York, v. 78, p. 137-156, 2004.

FEARNSIDE, P. M.; BARBOSA, R. I. Accelerating deforestation in Brazilian Amazonia: towards answering open questions. Environmental Conservation, Cambridge , v. 31, p. 7-10, 2004.

FERREIRA JUNIOR, L. G.; FERREIRA, N. C.; IGLIORI, D. Sistema de reserva legal extrapropriedade em Goiás: análise de custos e benefícios econômicos e ambientais à escala da paisagem. Boletim Goiano de Geografia, Goiania, v. 27, p. 11-25, 2007.

GALETTI, M. Indians within conservation units: lessons from the Atlantic Forest. Conservation Biology, Oxford, v. 15, n. 3, p. 791-792, 2001. 
INSTITUTO NACIONAL DE PESQUISAS ESPACIAIS. Projeto PRODES: monitoramento da floresta Amazônica Brasileira por satélite. Instituto Nacional de Pesquisas Espaciais: São José dos Campos, 2007. Disponível em: <http://www.obt.inpe.br/ prodes>. Acesso em fev. 2007.

LIMA, A. Aplicação de geoprocessamento na análise da representatividade dos sistemas de unidades de conservação no Estado do Mato Grosso. 137f. 2005. Dissertação (Mestrado em Sensoriamento Remoto) - Divisão do Sensoriamento Remoto, Instituto Nacional de Pesquisas Espaciais, São José dos Campos, 2005.

LIMA, A.; SHIMABUKURO, Y. E.; ANDERSON, L. O.; TOREZAN, J. M. D.; RUDORFF, B. F. T.; RIZZI, R. Atualização cartográfica do mapa de cobertura do Mato Grosso através da integração de mapas provenientes de imagens TM e MODIS. In: SIMPÓSIO BRASILEIRO DE SENSORIAMENTO REMOTO, 13., 2007, Florianópolis. Anais... São José dos Campos: INPE, 2007. p. 1711-1717.

MATO GROSSO. Fundação Estadual do Meio Ambiente. Legislação Ambiental, 2006. Disponível em: <http://www.fema.mt.gov.br/>. Acesso em fev. 2007.

Secretaria de Estado do Planejamento e Desenvolvimento. Mapa: zoneamento sócio econômico ecológico do Estado de Mato Grosso. 2004. Disponível em $<$ http://www.seplan.mt.gov.br/>. Acesso em fev. 2007.

MORTON, D. C.; DeFRIES, R. S.; SHIMABUKURO, Y. E.; ANDERSON, L. O.; ESPIRITO-SANTO, F. B.; FREITAS, R. et al. Cropland expansion changes deforestation dynamics in the southern Brazilian Amazon. Proceedings of the National Academy of Sciences, Washington, v. 103, n. 39, p. 14637-14641, 2006.

MORTON, D. C.; SHIMABUKURO, Y. E.; FREITAS, R.; ARAI, E.; DeFRIES, R. S. 2007. Secondary forest dynamics and Cerradão loss in Mato Grosso during 2001-2005 from MODIS phenology time series. In: SIMPÓSIO BRASILEIRO DE SENSORIAMENTO REMOTO, 13., 2007, Florianópolis. Anais... São José dos Campos: INPE, 2007. p. 6859-6866.

NEPSTAD, D. C.; McGRATH, D.; ALENCAR, A.; BARROS, A. C.; CARVALHO, G.; SANTILLI, M. et al. Frontier governance in Amazônia. Science, Washington, v. 295, p. 629-630, 2002.

NEPSTAD, D. C.; SCHWARTZMAN, S.; BAMBERGER, B.; SANTILLI, M.; RAY, D.; SCHLESINGER, P. et al. Inhibition of Amazon deforestation and fire by parks and indigenous lands. Conservation Biology, Oxford, v. 20, n. 1, p. 65-73, 2006.

NEPSTAD, D. C.; STICKLER, C. M.; ALMEIDA, O. T. Globalization of the Amazon soy and beef industries: opportunities for conservation. Conservation Biology, Oxford, v. 20, n. 6, p. 1595-1603, 2006.

NOSS, R. F.; COOPERIDER, A. Y. Saving nature's legacy. Washington: Island Press, 1994.

OYAMA, M. D.; NOBRE, C. A. A new climate-vegetation equilibrium state for tropical South America. Geophysical Research Letters, Washington, v. 30, n. 23, p. 2199, 2003. 
RIBEIRO, R. Revolução no campo. National Geographic Brasil, São Paulo, v. 48, n. 5, p. 26-33, 2004.

SANTILLI, M.; MOUTINHO, P.; SCHWRTZMAN, S.; NEPSTAD, D. C.; CURRAN, L. M.; NOBRE, C. A. Tropical deforestation and the Kyoto Protocol. Climatic Change, New York, v. 71, p. 267-276, 2005.

SCHWERTZMAN, S.; NEPSTAD, D. C.; MOREIR, A. Arguing tropical forest conservation: people versus parks. Conservation Biology, Oxford, v. 14, n. 5, p. 1370-1374, 2000.

SHIMABUKURO, Y. E.; DUARTE, V.; MOREIRA, M. A.; ARAI, E.; RUDORFF, B. F. T.; ANDERSON, L. O. et. al. Detecção de áreas desflorestadas em tempo real: conceitos básicos, desenvolvimento e aplicação do Projeto DETER. São José dos Campos: INPE, 2005. (Ministério da Ciência e Tecnologia, 63).

SHIMABUKURO, Y. E.; SMITH, J. A. The least-squares mixing models to generate fraction images derived from remote sensing multispectral data. IEEE Transactions on Geoscience and Remote Sensing, Piscataway, v. 29, p. 16-20, 1991.

SOARES FILHO, B. S.; NEPSTAD, D. C.; CURRAN, L. M.; CERQUEIRA, G. C., GARCIA, R. A.; RAMOS, C. A. et al. Modeling conservation in the Amazon basin. Nature, London, v. 440, p. 520-523, 2006.

TERBORGH, J. The fate of tropical forests: a matter of stewardship. Conservation Biology, Oxford , v. 14, n. 5, p. 1358-1361, 2000.

WORLD WILD LIFE FUND. Priority ecoregions. 2004. Disponível em: <http://www.worldwildlife .org/science/ecoregions.cfm>. Acesso em fev. 2007. 


\title{
Spatial and temporal characterization of some water quality physical parameters and their relationships with land-use in Água Fria watershed (Palmas - TO, Brazil) \\ (doi:10.4136/ambi-agua.17)
}

\author{
Alexandre Marco Silva1; Harry Edmar Schulz \\ ${ }^{1}$ Departamento de Engenharia Ambiental, UNESP, Sorocaba, SP, Brasil \\ E-mail: amsilva@sorocaba.unesp.br \\ ${ }^{2}$ Departamento de Hidráulica e Saneamento, Escola de Engenharia de São Carlos, USP, SP, Brasil \\ E-mail: heschulz@sc.usp.br
}

\begin{abstract}
Due to a high population growth that has been occurring in Palmas and due to land use changes that are caused by this population growth and development, the goal of this paper was to study the behavior of four physical parameters of water quality of the Água Fria watershed. The parameters were turbidity, total suspended solids, settleable solids and total dissolved solids. Eight gauging stations were established and the water samples were monthly collected from February/1998 to February/1999. The water bodies of the watershed were generally in good condition concerning these four parameters. However, there were some cases of seasonal irregularity of some parameters, as well as no correlation among some of studied parameters. This might be an indicator of some impacts like accelerated erosion due to a misuse of the lands and misuse of local water resources.
\end{abstract}

Keywords: water quality indicators; sediment pollution; watershed; Palmas-Tocantins, Brazil.

\section{Caracterização Espacial e temporal de alguns parâmetros físicos de qualidade da água e suas relações com o uso da terra na microbacia do Ribeirão Água Fria (Palmas - TO)}

\section{RESUMO}

Devido ao alto crescimento populacional ocorrente em Palmas e devido também às mudanças de uso da terra que são causadas devido a este crescimento, o objetivo deste trabalho foi estudar o comportamento de quatro parâmetros físicos indicadores de qualidade de água em corpos d’água localizados na microbacia do Ribeirão Água Fria. Os parâmetros estudados foram turbidez, sólidos suspensos totais, sólidos sedimentáveis e sólidos totais dissolvidos. Oito pontos de amostragem de água foram estabelecidos e as coletas procederamse mensalmente entre fevereiro de 1998 e fevereiro de 1999. Os corpos d'água da microbacia do Ribeirão Água Fria estavam em condições gerais consideradas satisfatórias com relação a estes quatro parâmetros. Contudo, notou-se certa irregularidade sazonal de alguns parâmetros, bem como correlações não significativas entre alguns dos parâmetros estudados. Isto pode ser um indicador de um início de degradação da qualidade da água devido a causas como erosão acelerada e uso não planejado dos recursos hídricos locais.

Palavras-chave: indicadores de qualidade da água; poluição por sedimentos; microbacia hidrográfica; Palmas, TO. 


\section{INTRODUCTION}

Sediment comes from soil erosion and suspended solids from watershed surfaces. Sediment is a natural component of streams, but excessive sediment can be carried into streams from erosion of unstable streambanks, construction sites, agricultural activities, and urban runoff. During erosion, the selectivity on the removal phase and transport of the particles results in a very rich sediment with higher amount of nutrients, organic matter and clay than the original soil where the particle was removed (Sparovek, 1996). If runoff occurs, the clay and organic matter, which are finer particles, are transported easier and faster than the coarser fractions (Bertoni; Lombardi Neto, 1990).

In the complete erosion-sedimentation cycle, the consequences of erosion are not only concerned with the soil loss but also with the transport of sediments and organic material into the rivers and their deposition (Beasley, 1972; Carvalho, 1998). Sediment is likely the most significant of all pollutants in relation to concentration in the water, its impacts on the water use, and its effects on the transport of other pollutants (Ward; Elliot, 1995). It is a significant pollutant in many Brazilian watersheds. Excessive sediment concentrations in the water column can be harmful to aquatic life and will exacerbate the toxic effects of other pollutants. Sediment deposits within streams degrade habitat for macroinvertebrates and fish communities. Finally sediment carries other types of contaminants into the aquatic system such as nutrients, organic compounds (e.g. pesticides), and heavy metals (Esteves, 1988).

There are several parameters that indicate the degree of influence of the sediment on the water quality. Turbidity, one of the most widely used, is a measure of the collective optical properties of a water sample that causes light to be scattered and absorbed rather than transmitted in straight lines. The Turbidity, when measured in Nephelometric Turbidity Units (NTU), uses nephelometric methods that depend on passing specific light of a specific wavelength through the sample (Eaton et al., 1995).

The Settleable Solid (S.S.) is another parameter widely used to characterize water quality. It is defined as the amount of solids that will settle under quiescent conditions in the influence of gravity. It may be determined and reported in either a volume $\left(\mathrm{ml}^{-1} \mathrm{l}^{-1}\right)$ or weight basis (mg. l $^{-1}$ ) (Eaton et al., 1995).

Total dissolved solids (T.D.S.) comprise inorganic salts and small amounts of organic matter that are dissolved in water. The principal constituents are usually the cations calcium, magnesium, sodium and potassium; and the anions carbonate, bicarbonate, chloride, sulphate and nitrate. The concentration of TDS in water in contact with granite, siliceous sand, wellleached soil or other relatively insoluble materials is usually below $30 \mathrm{mg} . \mathrm{l}^{-1}$. At levels above $500 \mathrm{mg} . \mathrm{l}^{-1}$, excessive hardness, unpalatability, mineral deposition and corrosion may occur. At lower levels, however, TDS contributes to turn better the water palatability (Eaton et al., 1995).

Total suspended solids (T.S.S.) concentrations indicate the amount of suspended solids in water, whether mineral (e.g., soil particles) or organic (e.g., algae). The T.S.S. test measures an actual weight of material per volume of water. TSS concentrations are reported in units of milligrams of suspended solids per liter of water - mg. $^{-1}$. High concentrations of particulate matter affect light penetration and primary productivity, recreational values, and habitat quality of the affected environment. Particles also provide the aggregation of other particulate pollutants, notably metals and bacteria (Azevedo Netto, 1991; Eaton et al., 1995).

Indirectly, the suspended solids affect other parameters such as temperature and dissolved oxygen. Because of the greater heat absorbance of the particulate matter, the surface water becomes warmer and this tends to stabilize the stratification (layering) in stream pools, 
embayment, and reservoirs. This, consecutively, interferes with mixing, decreasing the dispersion of oxygen in deeper layers.

Suspended solids (S.S.) cause interference in the effective drinking water treatment. High sediment loads interfere with coagulation, filtration, and disinfection. More chlorine is required to effectively disinfect turbid water. They also cause problems for industrial users. Suspended sediments also interfere with recreational use and aesthetic enjoyment of water.

Sediment deposition eventually may close up channels or fill up the water body converting it into a wetland. A positive effect of the presence of suspended solids in water is that toxic chemicals such as pesticides and metals tend to adsorb to them or become complexed with them which make the toxics less available to be absorbed by living organisms.

The central region of the Tocantins state (Brazilian Northern region), most precisely its capital (Palmas), has as been experimenting high rates of human population and urbanization. Palmas is a young city that in 1989 was created to be the business and politic center of Tocantins State. Then, high rates of deforestation and increased negative impacts of land cover change on water quality of the streams that pass through the city are starting to emerge, and may be related to increasing human population (due mainly to migration).

The aim of this paper was to determine if the physical condition of the streams located in the Água Fria watershed (Palmas - Tocantins, Brazil) have been altered due to increasing human population and land use development.

\section{The Study Site}

The Água Fria watershed has $7.6 \mathrm{Km}^{2}$ and is fully inserted in the municipal area of Palmas (Tocantins, Brazilian northern region). Geographical coordinates are: $48^{\circ} 16^{\prime}$ and $48^{\circ}$ $23^{\prime}$ west longitude and $10^{\circ} 03^{\prime}$ and $10^{\circ} 20^{\prime}$ south latitude (Silva, 1999). The main climatic characteristics observed indy area are annual average temperature $24^{\circ} \mathrm{C}$ and annual average rainfall depth 1,300 mm (Nimer, 1979).

The relief of the Água Fria watershed is steep on the headwater regions (high parts of the watershed) and smoothly waved near the estuary. Along the steepest region, geologic basement is crystalline and in regions where the relief is smoothly waved the geologic basement is sedimentary (Brasil, 1981).

The soil classes that are found on the study area (Ranzani, 1998) are (according to F.A.O. classification system): Plinthosol, occurring on 27.8\% of the area; Rhodic Ferralsol (28.0\%); Leptosol (10.3\%); Xanthic Ferralsol (17.3\%); Cambissol (8.0\%); Gleysol (7.6\%). Bare rock is also found in $1.0 \%$ of the area.

Hydrography of the Água Fria watershed is composed of three main water courses: Brejo Comprido, Suçuapara and Água Fria. The headwaters of the Água Fria and Brejo Comprido are located in the Lajeado's hill, while the Suçuapara has its unique headwater located in the city of Palmas, where the relief is smoothly waved. This watershed has crucial importance for the population that lives in Palmas because a significant part of the drinking water that is consumed in the city comes from the Água Fria stream.

The main land use classes used in this study are: water bodies (occupying $0.27 \%$ of the total area), areas for environmental protection (68.28\%), agricultural areas (61.80\%), urban settlement (30.45\%) and areas experimenting urban expansion (6.74\%). In the Area for Environmental Protection (named "Área de Proteção Ambiental da Serra do Lajeado") the predominant land cover is natural vegetation, despite of presenting some unpaved roads and some patches with burnt vegetation (especially in the dry season). The "water bodies" class represents some small dams and lakes found along the study area. 


\section{METHODS}

Eight gauging stations were established along the Água Fria watershed (Figure 1). These stations were established according to the accessibility and local. During the period from Feb/1998 to Jan/1999 three water samples (approximately 2 liters) were collected according to the vertical integration method described by Carvalho (1994).

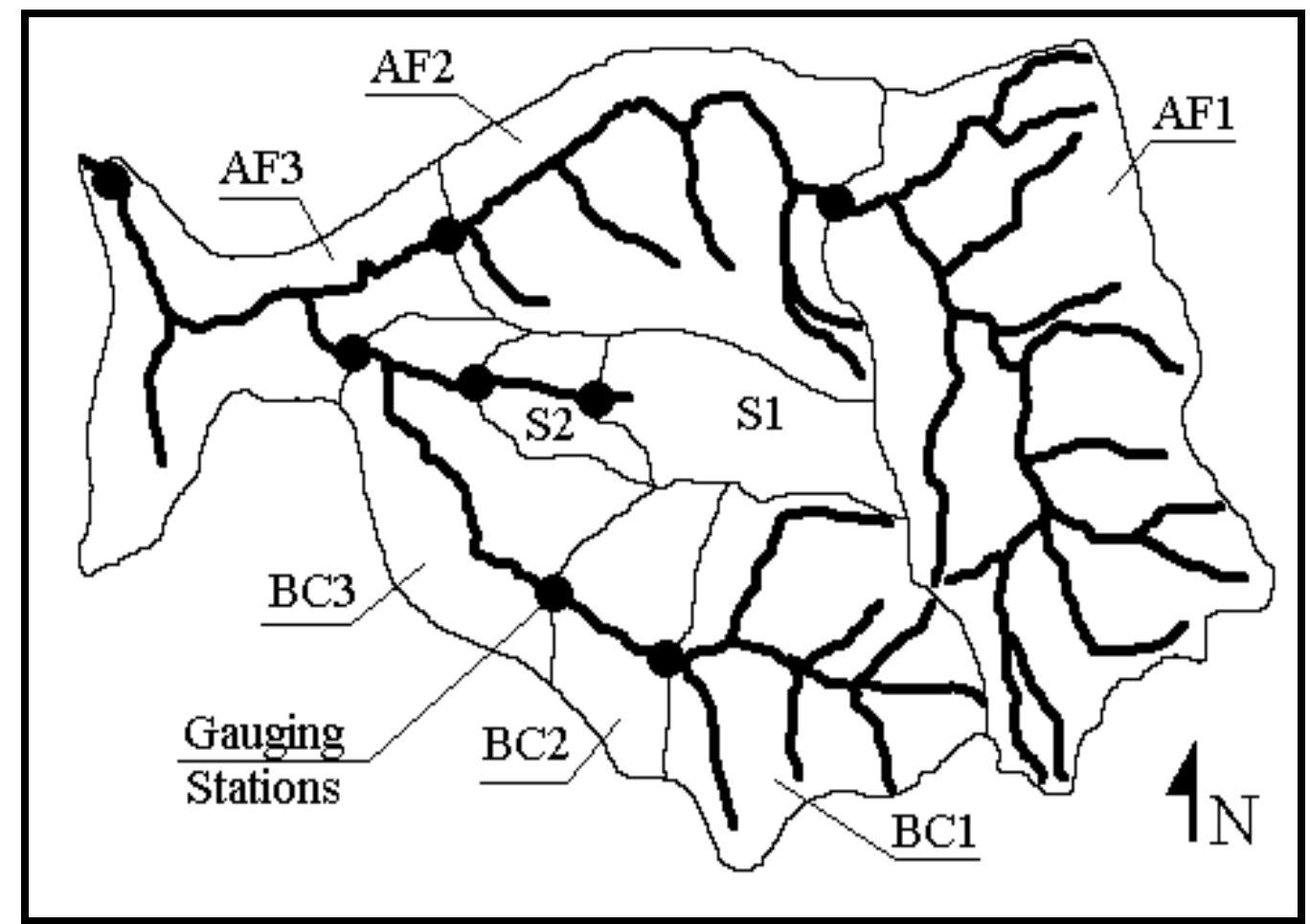

Figure 1. Map showing the eight stations established. The division lines of the sub watersheds were determined according to the topography of the region.

In laboratory total dissolved solids were quantified using the evaporation method (Gandolfi, 1971; Eaton et al., 1995; Pião, 1995). Settleable solids were quantified with an Imhoff cone (1 liter sample / 1 hour time - see more details in Eaton et al., 1995). Turbidity was quantified with a Hach 2100P turbidimeter. Dissolved solids were quantified with a Prob 50161 conductivimeter. The parameter Dissolved Solids was not quantified for the February/1998 because the conductivity meter was out of work. The spatial and temporal variations were compared through the determination of the variation coefficient (eq. 1).

$$
\mathrm{VC}(\%)=\frac{\mathrm{S}_{\mathrm{i}}}{\overline{\mathrm{X}_{\mathrm{i}}}} * 100
$$

where:

$\mathrm{VC}$ - variation coefficient (\%).

$\mathrm{S}_{\mathrm{i}}$ - Standard deviation of the monthly values of the parameter "i".

$\bar{X}_{i}$ - Mean value of the monthly values of the parameter “i”.

A correlation matrix among the parameters was computed. 


\section{RESULTS AND DISCUSSION}

Figure 2 shows the seasonal variation of turbidity values for the eight sub watersheds during the study period. The values of turbidity ranged from 2.3 to $215.0 \mathrm{NTU}$ and in most occasions the values were considered low. According to Mota (1995), values higher than 100 NTU indicate that the water resource cannot be used for recreation activities. Just in five occasions the values were higher than 100 NTU. This indicates that the water was still good for recreational purposes almost all year long. The spatial variability was smaller than the temporal variability (V.C. $84.4 \%$ and $100.1 \%$, respectively).

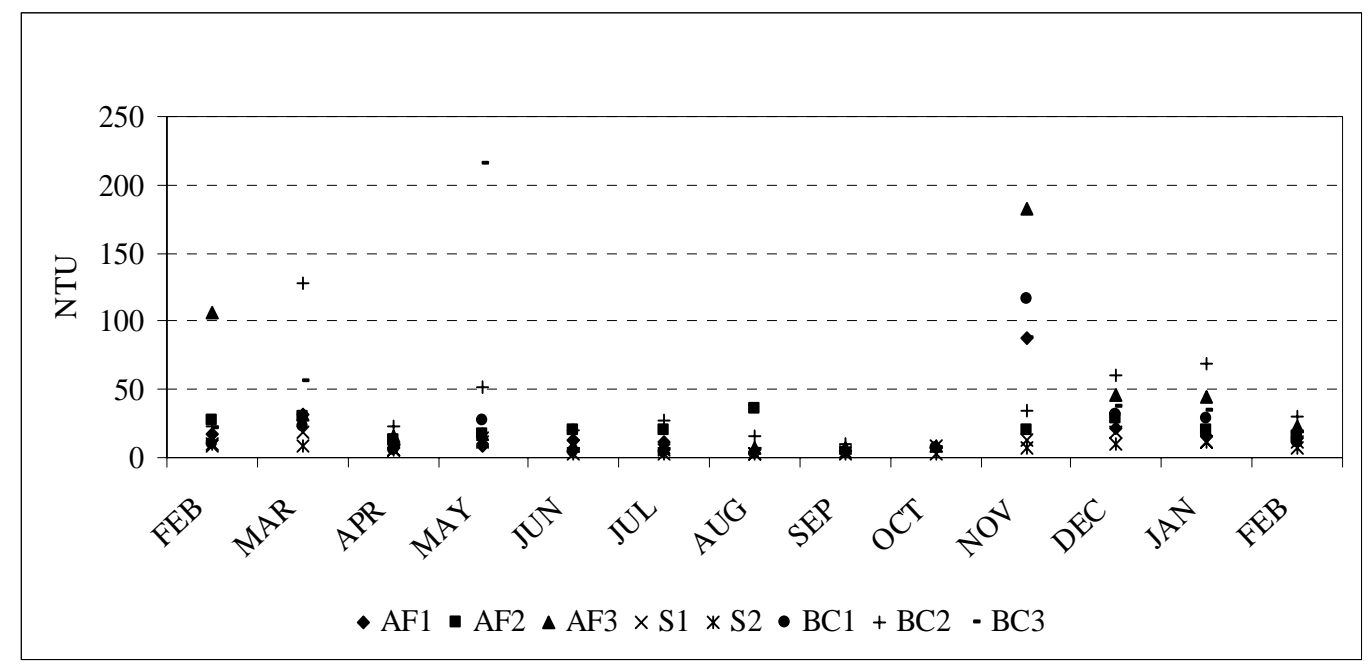

Figure 2. Monthly values of Turbidity for the study area.

Three sub-watersheds presented similar annual values of turbidity (average monthly values): AF3, BC2 and BC3 (respectively 38.8, 38.4 and 38.9 NTU). BC2 presented the highest value for seven months, while AF1, S2 and BC1 did not presented an extremely high value in any month. It is interesting to note that the BC2 station was located 150 meters downstream of the Parque Cesamar's lake (a recreational area). In both BC2 and BC3 subwatersheds some gullies were observed near Brejo Comprido stream. This might be an important source of sediment that modify water quality and fluvial characteristics of the water bodies (Silva, 1999).

For the parameter Dissolved Solids the values were also low during the study period for all gauging stations. The values ranged from 0.9 to $13.0 \mathrm{mg} . \mathrm{l}^{-1}$. The AF1 sub-watershed presented the highest average value $\left(9.3 \mathrm{mg}^{-1} \mathrm{l}^{-1}\right)$. The monthly values of dissolved solids are shown in Figure 3.

This parameter presented spatial variability higher than the temporal variability (V.C. $32.6 \%$ and $27.8 \%$ respectively), although both variations were low. The annual average value for the study area was $5.8 \mathrm{mg} . \mathrm{l}^{-1}$. The average value for the dry season was $4.8 \mathrm{mg} . \mathrm{l}^{-1}$ while the average value for the wet season was $6.8 \mathrm{mg}^{-1}{ }^{-1}$.

Christofoletti (1981) shows values of dissolved solids for many rivers of the Amazon region and in a general way the values ranged from 4.0 to $248.0 \mathrm{mg} . \mathrm{l}^{-1}$. For the Negro river basin the average value was $6.0 \mathrm{mg}^{-1} \mathrm{l}^{-1}$ in the dry season and $4.0 \mathrm{mg} . \mathrm{l}^{-1}$ in the wet season, while for the Madeira river basin the average values were $68.0 \mathrm{mg} . \mathrm{l}^{-1}$ in dry season and 50.0 mg. $\mathrm{l}^{-1}$ in the wet season. 

and their relationships with land-use in Água Fria watershed (Palmas - TO, Brazil). Ambi-Agua, Taubaté, v. 2, n. 1, p. 21-29, 2007. (doi:10.4136/ambi-agua.17)

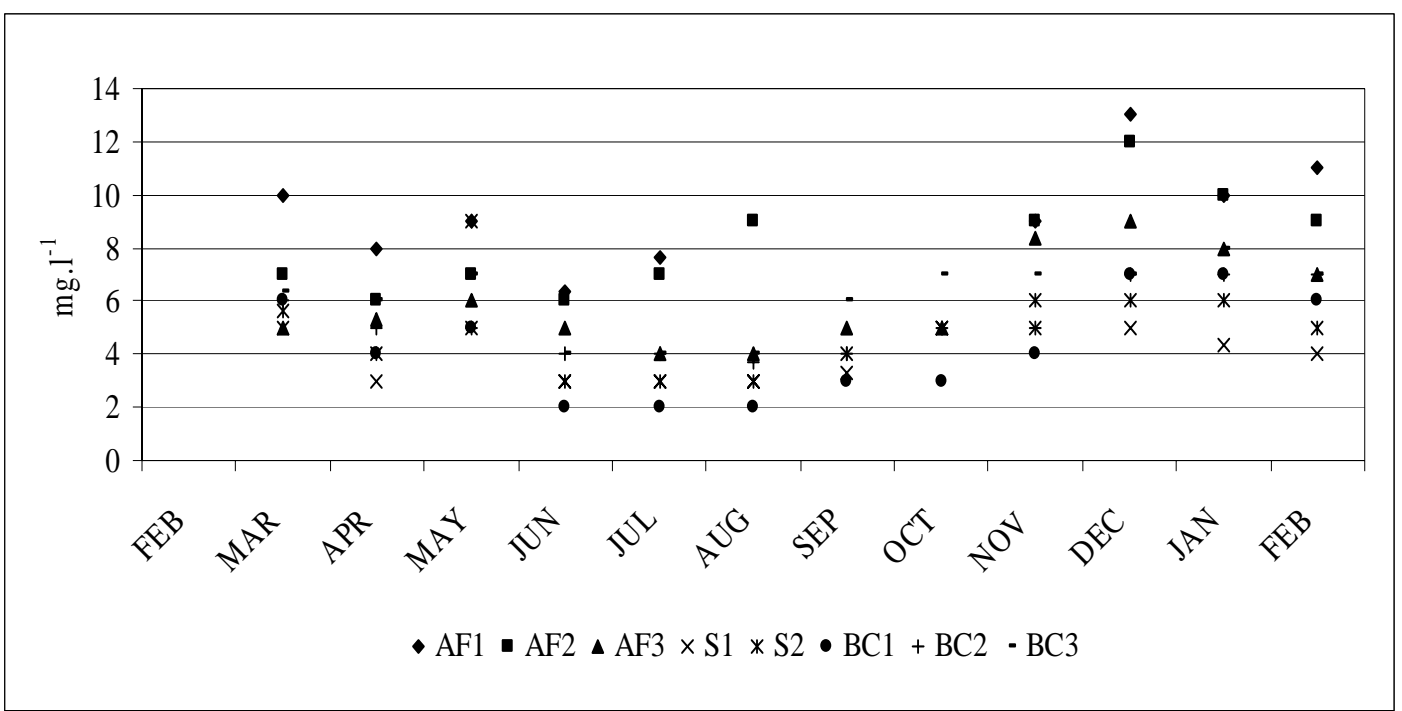

Figure 3. Monthly values for Dissolved Solids.

Regarding the values shown by Christofoletti (1981) for the Amazon region, the values of dissolved solids for the dry season were higher than the values for the wet season in all watersheds. This fact does not agree with the values found on this study, and may indicate and anomaly associated with the water characteristics of the streams.

Similarly, Daniel et al. (2002) showed, graphically, some abnormality on the seasonality of the Electric Conductivity (an indirect indicator of the amount of dissolved solids in water) for ten sub-watersheds of the Piracicaba river basin (SP, Brazil). The authors associated those results mainly to the dispersal of untreated urban sewage into the streams. For Água Fria watershed, despite of having a percentage of urban area proportionally higher than this other study (Água Fria: 20\% and the other cases approximately 15\%), the domestic sewage is still discharged into septic tanks. On the other hand, many people have used the streams for washing cars, depositing solid waste, and other purposes that might cause the degradation of the study area water bodies.

Total Suspended Solids showed the highest temporal variation among all parameters during the study period (V.C. $111.3 \%$ ), while the spatial variation was V.C. 52.5\%. The values ranged from 45.3 to $4,841.0 \mathrm{mg} . \mathrm{l}^{-1}$ and the mean value obtained for the watershed

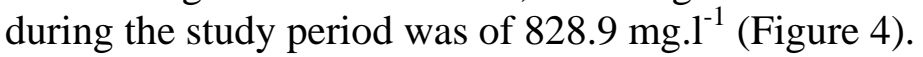

This average value found for this watershed contradicts the founding of Christofoletti (1981) who stated that in Brazilian rivers the amount of suspended material is normally low (smaller than $100 \mathrm{mg}^{-1} \mathrm{l}^{-1}$ ). For the Amazon River, for instance, the author shows an average value of 90 mg. $\mathrm{l}^{-1}$ with the values ranging from $1 \mathrm{mg} . \mathrm{l}^{-1}$ in the dry season for the Negro, Tapajós and Xingu rivers to $728 \mathrm{mg}^{-1} \mathrm{l}^{-1}$ in the wet season for the Ucaiali River. On the other hand, the same author presented values of $43 \mathrm{mg} . \mathrm{l}^{-1}$ of dissolved material and $550 \mathrm{mg} . \mathrm{l}^{-1}$ of particle material in the dry season and values of $10 \mathrm{mg} \cdot \mathrm{l}^{-1}$ of dissolved material and 1,200 mg. $\mathrm{l}^{-1}$ of particle material in the wet season for Paraíba do Sul River (Barra do Piraí, RJ southeast region of Brazil).

Mota (1995) showed for São Carlos-SP (southeast region of Brazil) values ranging from 171.0 to $3,499.0 \mathrm{mg} . \mathrm{l}^{-1}$ for urban runoff waters. This shows that when the watershed is largely urbanized one of the main environmental disturbances that occurs is the change on sedimentological balance, as also affirmed by Wilson Jr. (1996). 
SILVA, A. M.; SCHULZ, H. E. Spatial and temporal characterization of some water quality physical parameters and their relationships with land-use in Água Fria watershed (Palmas - TO, Brazil). Ambi-Agua, Taubaté, v. 2, n. 1, p. 21-29, 2007. (doi:10.4136/ambi-agua.17)

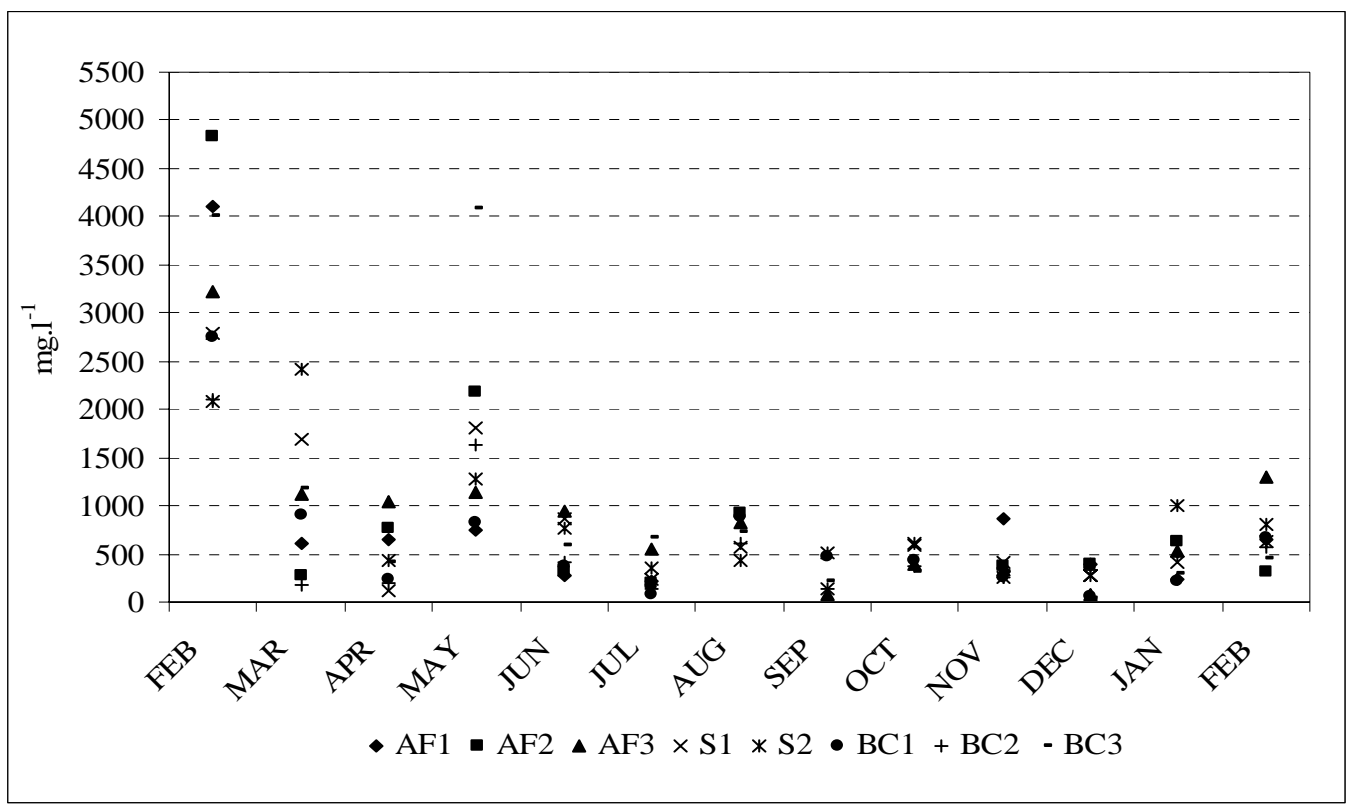

Figure 4. Monthly values of Total Suspended Solids for the study area.

Settleable solids ranged from 0.01 to $5.13 \mathrm{ml}^{-\mathrm{l}^{-1}}$. Significant correlation $(\mathrm{r}=0.65$, significant $\alpha=1 \%$ ) between settleable solids and water flow was found (water flow values were obtained in Silva and Schulz (in press)). AF3 was the sub-watershed that presented the highest values almost all year long, except September and October (Figure 5), when the S1 sub-watershed presented the highest values. Despite this seasonal situation observed in the study area, it is impossible to state that urbanization had expressive influence in the values of this parameter. Because, differently than expected, the BC3 sub-watershed (located downstream of the urban settlement) did not show similar results. Therefore, the erosion process (channel erosion) might be the main environmental degradation agent that occurred in the AF3 sub watershed along with the main type of soil (sandy gleysol), reported by Silva (1999).

The results obtained by correlation analysis are shown on Table 1 . The turbidity showed significant correlation with all parameters studied. It can be seen that this parameter is the most affected by the presence of sediment, as also reported by Azevedo Netto (1991) and Ward and Elliot (1995). Despite the significant correlation found among turbidity and other parameters, it is important to say that the turbidity is a qualitative parameter and cannot be considered directly as amount of suspended solids per liter, as discussed by Riley (1998). This affirmation can be supported by the significant but "low" " $r$ " value found between total suspended solids and turbidity $(\mathrm{r}=0.33)$. This correlation may occasionally present a high $\mathrm{r}$ value, probably in pristine water bodies.

Table 1. Correlation matrix among the monthly values of water flow (FLOW), settleable solids (S.S.), total suspended solids (T.S.S.), turbidity (TURB) and dissolved solids (D.S.).

\begin{tabular}{|c|c|c|c|c|c|c|c|c|}
\hline & \multicolumn{2}{|c|}{ S.S. } & \multicolumn{2}{|c|}{ T.S.S. } & \multicolumn{2}{|c|}{ TURB } & \multicolumn{2}{|c|}{ D.S. } \\
\hline FLOW & 0.65 & $(* *)$ & 0.21 & $(*)$ & 0.29 & $(* *)$ & 0.20 & \\
\hline S. S. & & & 0.13 & & 0.25 & $(*)$ & -0.04 & \\
\hline T.S.S. & & & & & 0.33 & $(* *)$ & 0.10 & \\
\hline TURB & & & & & & & 0.29 & $(* *)$ \\
\hline
\end{tabular}




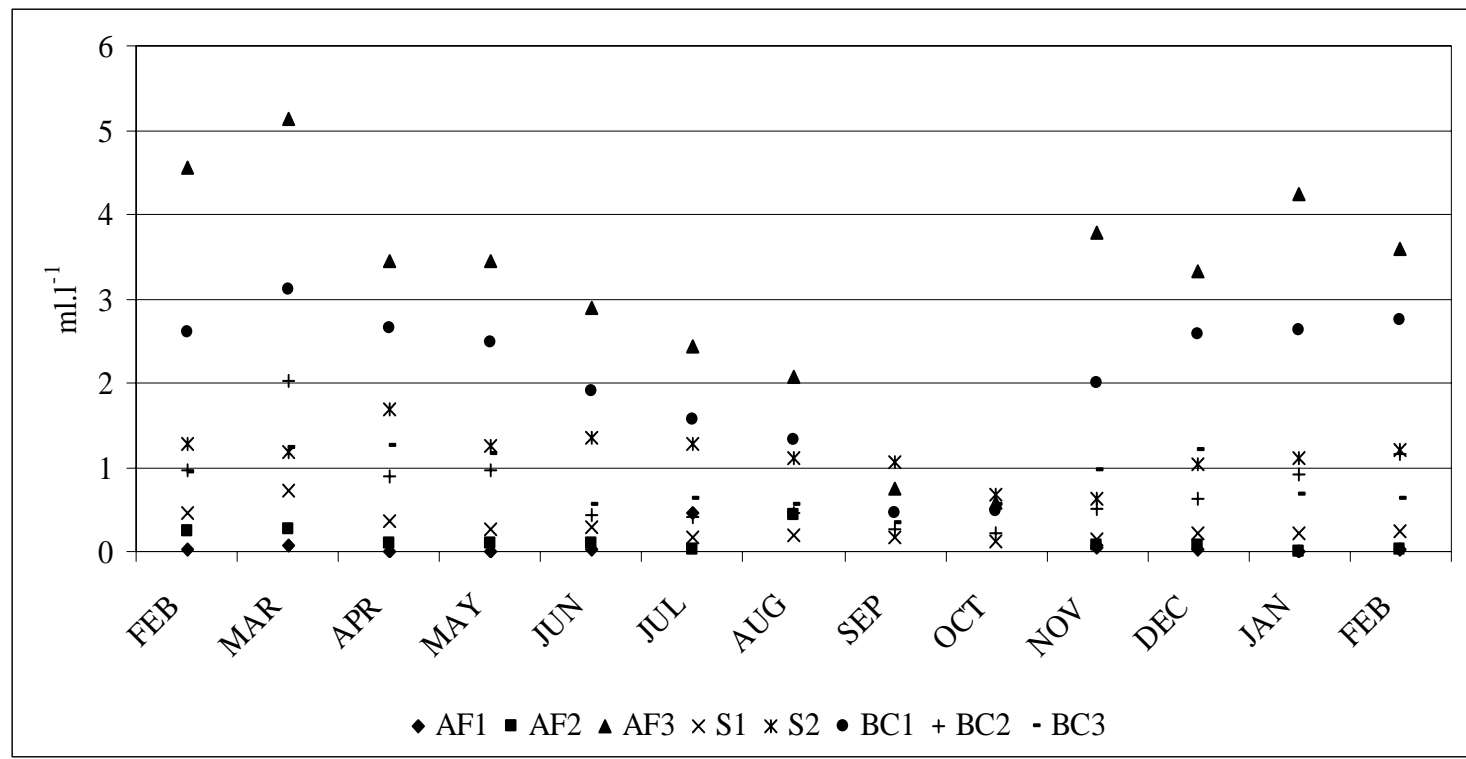

Figure 5. Monthly values of Settleable Solids for study area.

\section{CONCLUSIONS}

The four water quality indicators studied showed that water quality of the Água Fria watershed streams were still in good condition. But the non-correlation observed between some parameters suggests that some equilibrium modification of the hydrosedimentological cycle might be already ccurring. This imbalance may be due to the intensive misuse of this water resource for many purposes.

\section{ACKNOWLEDGEMENTS}

We thank Odo Primavesi and Hélio do Prado for help on translate of the soil classes from Brazilian to International System. We also thank CNPq by financial support.

\section{REFERENCES}

AZEVEDO NETTO, J. M. Manual de saneamento de cidades e edificações. São Paulo: PINI, 1991.

BEASLEY, R. P. Erosion and sediment pollution control. Iowa: University Press, 1972.

BERTONI, J.; LOMBARDI NETO, F. Conservação do Solo. São Paulo: Ícone, 1990.

BRASIL. Ministério de Minas e Energias. Departamento Nacional de Produção Mineral. Projeto RadamBrasil. Levantamento dos recursos naturais: folha SC 22: Tocantins. Rio de Janeiro: [S.n.], 1981.

CARVALHO, N. O. Assoreamento e proteção de reservatórios. In: NATIONAL SYMPOSIUM OF EROSION CONTROL, 6., 1998, Presidente Prudente. Proceedings... Presidente Prudente: [S.n.], 1998. 1 CD-ROM.

Hidrossedimentologia prática. Rio de Janeiro: CPRM, 1994.

CHRISTOFOLETTI, A. Geomorfologia fluvial. São Paulo: Edgard Blücher, 1981. 
DANIEL, M. H. B.; MONTEBELO, A. A.; BERNARDES, M. C.; OMETTO, J. P. H. B.; et al. Effects on urban sewage on dissolved oxygen, dissolved inorganic and organic carbon, and electrical conductivity on small streams along a gradient of urbanization in the Piracicaba river basin. Water, Air, and Soil Pollution, Dordrecht, v. 136, p.189206, 2002.

EATON, A. D.; CLESCERI, L. S.; GREENBERG, A. E. Standard methods for examination of water and waster water. 19 ed. Washington: EPA/APHA, 1995.

ESTEVES, F. A. Fundamentos de limnologia. Rio de Janeiro: FINEP, 1988.

GANDOLFI, N. Investigações sedimentológicas, morfométricas e físico-químicas nas bacias do Moji-Guaçu, do Ribeira e do Peixe. 1971. Tese (Livre-Docência) Departamento de Geologia e Mecânica dos Solos, Escola de Engenharia de São Carlos, Universidade de São Paulo, São Carlos, 1971.

MOTA, S. Preservação e conservação dos recursos hídricos. 2 ed. Rio de Janeiro: ABES, 1995.

NIMER, E. Climatologia do Brasil. Rio de Janeiro: Fundação IBGE, 1979. (Série Recursos Naturais e Meio Ambiente, 4).

PIÃO, A. C. Transporte de nitrogênio, fósforo e sedimentos pelo Ribeirão dos Carrapatos (Município de Itaí - SP), sua relação com usos do solo e outros impactos antropogênicos e a sua deposição no braço do Taquari (Represa de Jurumirim). 1995. Tese (Doutorado em Engenharia Ambiental) - Escola de Engenharia de São Carlos, Universidade de São Paulo, São Carlos, 1995.

RANZANI, G. Mapa de solos do município de Palmas, TO. [S.l.]: [S.n.], 1998. Escala $1: 100.000$.

RILEY, S. J. The sediment concentration-turbidity relation: its value in monitoring at Ranger Uranium Mine, Northern Territory, Australia. Catena, Kingswood, v. 32, n. 1, p. 1-14, 1998.

SILVA, A. M. Aplicações de técnicas de geoprocessamento no estudo das relações entre os processos erosivos e sedimentológicos de bacia hidrográfica. 1999. Tese (Doutorado em Engenharia Ambiental) - Escola de Engenharia de São Carlos, Universidade de São Paulo, São Carlos, 1999.

SILVA, A. M., SCHULZ, H. E. - Hydrosedimentological dynamic on Água Fria watershed (Palmas, TO) - Brazil). Brazilian Archives of Biology and Technology, Curitiba, in press. (http://everest3.tecpar.br/babt/).

SPAROVEK, G. Erosão do solo e a produtividade das culturas. In: LATIN-AMERICAN CONGRESS OF SOIL SCIENCE, 13., 1996, Águas de Lindóia. Proceedings... Águas de Lindóia: SBCS/USP-ESALQ, 1996. 1 CD-ROM.

WARD, A. D.; ELLIOT, W. J. Environmental hydrology. Boca Raton: Lewis Publishers, 1995.

WILSON JR., G. Quando os sedimentos se tornam poluentes. In: BRAZILIAN NATIONAL MEETING OF SEDIMENT ENGINEERING, 2., 1996, Rio de Janeiro. Proceedings... Rio de Janeiro: [S.n.], 1996. 


\title{
Mapeamento das Áreas de Preservação Permanente (APP) do município de Santo Antônio do Pinhal, SP: um subsídio à preservação ambiental
}

(doi:10.4136/ambi-agua.18)

\author{
Celso de Souza Catelani' ${ }^{1}$; Getulio Teixeira Batista ${ }^{2}$ \\ ${ }^{1}$ Geógrafo visitante do Laboratório de Geoprocessamento, Sensoriamento Remoto e Informática Rural da \\ Universidade de Taubaté (LAGEO) \\ E-mail: celso@agro.unitau.br \\ ${ }^{2}$ Professor do Programa de Pós-Graduação em Ciências Ambientais da Universidade de Taubaté (UNITAU) \\ E-mail: getulio@agro.unitau.br
}

\section{RESUMO}

O mapeamento das Áreas de Preservação Permanente (APPs) do município de Santo Antônio do Pinhal, SP, situado em uma área de grande interesse imobiliário na região serrana da Mantiqueira Paulista, especialmente pela proximidade do município turístico de Campos do Jordão, SP, deu-se, inicialmente, com o intuito de se produzir documentos cartográficos voltados a subsidiar as ações das autoridades ambientais responsáveis pela preservação destas áreas de APPs, já previstas na Lei 4.771/65 e, regulamentadas pelas Resoluções CONAMA 302 e 303/2002. Nesse contexto, este trabalho teve como objetivo a delimitação de APPs, na escala de 1:50.000, apoiado na utilização de técnicas no estado da arte das ferramentas computacionais de geoprocessamento e no tratamento de informações espaciais contidas em documento cartográfico oficial da Federação (Cartas Topográficas do IBGE na Escala de 1:50.000). Os resultados da análise e o mapeamento das áreas de preservação permanente do município de Santo Antônio do Pinhal demonstraram, em especial, duas situações de maior atenção: em primeiro lugar, destaca-se que as APPs abrangem uma área de 7.218 ha, equivalentes a 52,2\% da área total do município, um aspecto muito positivo do ponto de vista ambiental, porém extremamente restritivo em relação ao uso do solo. Em segundo, a ocorrência de APPs de Topo de Morro em uma área de 4.227 ha, correspondentes a 30,7\% da área total do município, o que demonstra o caráter restritivo ao uso da terra imposto por essa classe de APPs, especialmente em regiões com relevo ondulado como no domínio dos Mares de Morros em que se insere a área estudada.

Palavras-chave: áreas de preservação permanente; APP; legislação ambiental; geoprocessamento; SIG; SPRING.

\section{Mapping of Permanent Preservation Areas (PPA) of the municipal district of Santo Antônio do Pinhal, SP: base for environmental preservation}

\section{ABSTRACT}

The mapping of the Permanent Preservation Areas (PPAs) of the municipal district of Santo Antônio do Pinhal, SP, located in an area of great real estate interest in the Mantiqueira Moutains of São Paulo, neighbor of the touristic municipal district of Campos de Jordão, SP, became necessary. The need for producing cartographic documents is to support environmental authorities to establish plans for the preservation of these areas, especially the Permanent Preservation Areas (PPA) established by the Law 4,771/65 and regulated by the 
Resolutions CONAMA 302 and 303/2002. In that context, this work had as objective, the delimitation of Permanent Preservation Areas (PPA) at the 1:50,000 scale. The analysis and results of the mapping of the permanent preservation areas of the municipal district of Santo Antônio do Pinhal revealed two situations that deserve attention: first, the total area of PPAs corresponds to an area of 7,218ha which is equivalent to $52.2 \%$ of the total area of the municipal district. This is very positive for the environmental point of view, however, extremely restrictive for land use. The occurrence of PPAs in the class of "Top of Hills" reaches 4,227 ha which correspond to $30.7 \%$ of the total area of the municipal district. This demonstrates the restrictive character of land use of that PPA class, especially in areas with undulated relief as it is the case of the geomorphological domain known as "Mar de Morros" where the study area is located.

Keywords: permanent preservation areas; environmental legislation; geoprocessing; GIS; SPRING.

\section{INTRODUÇÃO}

O Vale do Paraíba sofreu ao longo do último século grande degradação ambiental por estar inserido entre os dois maiores pólos urbanos do país: São Paulo e Rio de Janeiro. Uma série de ciclos de exploração agrícola, como o da cana de açúcar e do café, substituídos pela agropecuária após a degradação dos solos devido à erosão, fez com que a derrubada da floresta primitiva se processasse de forma drástica. Há cem anos, apenas as formações florestais cobriam mais de 70\% do território paulista (Victor, 1979); hoje a cobertura vegetal nativa do Estado de São Paulo está estabilizada ao redor de 13,5\% da sua extensão territorial (Kronka et al., 2005). O Vale do Paraíba seguiu essa tendência de diminuição da cobertura vegetal nativa (Saito, 1995).

Por outro lado, o Código Florestal Brasileiro instituído em 1965 (Brasil, 1965), seguido por vários outros documentos legais, impõe restrições sobre o uso de áreas denominadas “Áreas de Preservação Permanente” (APPs). Nessas áreas não se pode fazer a retirada da cobertura vegetal original, para permitir, assim, o exercício pleno de suas funções ambientais (Ribeiro et al., 2005). No entanto, devido à tradição de uso intensivo do solo no passado e à dificuldade de imposição desse código, pouco se tem feito para verificar o uso atual dessas áreas.

Entretanto, existe hoje uma conscientização maior por parte da comunidade da necessidade de preservação dos recursos naturais, especialmente a partir da reunião de cúpula no Rio de Janeiro em 1992, onde foi assinada a Convenção sobre Mudanças Climáticas (MCT, 2002), seguida da instituição do Protocolo de Quioto (Miguez, 2002) sobre a redução da emissão de gases de efeito estufa, bem como o crescimento da atuação das ONGs ambientalistas. Seguindo essa preocupação, o Ministério Público no Estado de São Paulo tem atuado no sentido de fazer valer a legislação ambiental vigente. Há que se ressaltar a importância da preservação da vegetação de floresta para a melhoria da qualidade e quantidade de água, hoje, já em crise para o abastecimento da região (Rebouças et al., 1999), assim como, para a conservação da diversidade (Pincinato, 2005).

As técnicas de Geoprocessamento e Sensoriamento Remoto constituem, hoje, um importante conjunto de ferramentas aplicáveis ao planejamento geográfico para a obtenção de dados a serem utilizados no planejamento e zoneamento, tanto em níveis regionais quanto municipais. De fato, tem havido um desenvolvimento marcante das geotecnologias (Sensoriamento Remoto e Geoprocessamento) que disponibilizam uma série de ferramentas 
que auxiliam sobremaneira a investigação da adequação do uso do solo em áreas de preservação permanente (Aulicino et al., 2000; Costa et al., 1996). Entretanto, poucos trabalhos têm sido feitos para investigar e demonstrar a eficácia da tecnologia, especialmente na delimitação das áreas de usos restringidos pelo Código Florestal.

O município de Santo Antônio do Pinhal, situado na região da Serra da Mantiqueira, tem grande potencial turístico, especialmente na área rural, pelo seu clima de montanha, belezas naturais e sua localização ao lado do município de Campos do Jordão que é um dos maiores pólos turísticos do Estado. Além da importância socioeconômica, esse município foi escolhido para a validação da metodologia proposta pelas suas características geomorfológicas de região montanhosa que induzem um desafio maior na avaliação da tecnologia para a delimitação de APPs, especialmente de topo de morro.

Dessa forma, este trabalho teve como objetivo gerar um mapa contendo a delimitação das “Áreas de Preservação Permanente” previstas na legislação ambiental brasileira, de ocorrência no município (nascentes, margens de rios, declividade acima de $45^{\circ}$, altitude acima de $1.800 \mathrm{~m}$ e topo de morros, serras e montanhas) com base em mapas topográficos na escala 1:50.000 (IBGE, 1974), Código Florestal e posteriores documentos legais (Brasil, 1965; CONAMA, 1985 e 2002), por meio da geração de um modelo numérico do terreno utilizando funções no estado da arte de sistemas de informações geográficas disponibilizadas na versão do SPRING, v. 4.2 (Câmara et al., 1996), e, assim, gerar um produto que contém a representação cartográfica das áreas de preservação permanente (APPs) do município de Santo Antônio do Pinhal e apresentar uma abordagem metodológica do uso de geotecnologias na geração de um mapeamento da legislação ambiental sobre APPs.

\section{1. Áreas de Preservação Permanente}

As Áreas de Preservação Permanente (APPs) foram criadas para proteger o ambiente natural, o que significa que não são áreas apropriadas para alteração de uso da terra, Assim, essas áreas devem estar cobertas com a vegetação original. A cobertura vegetal nessas áreas irá atenuar os efeitos erosivos e a lixiviação dos solos, contribuindo também para regularização do fluxo hídrico, redução do assoreamento dos cursos d’água e reservatórios, e trazer também benefícios para a fauna (Costa et al., 1996). O Código Florestal Brasileiro define "As florestas existentes no território nacional e as demais formas de vegetação, reconhecidas de utilidade às terras que revestem, são bens de interesse comum a todos os habitantes do País, exercendo-se os direitos de propriedade, com as limitações que a legislação em geral e especialmente esta Lei estabelecem” (Art. $1^{\circ}$ Lei 4771/1965), conforme regulamentação no art. $2^{\circ}$ desta Lei ${ }^{\circ}$ 4.771, de 15 de setembro de 1965, (D.O.U. de 16/09/1965), no que concerne às Áreas de Preservação Permanente, as Resoluções CONAMA 302 e 303 de março de 2002 adotam novas definições com alterações significativas, principalmente, em relação às distâncias de fixação do limite de APPs, associadas à respectiva largura dos cursos d’água.

\section{MATERIAIS E MÉTODO}

\section{1. Área de Estudo}

Pela sua topografia e beleza natural, Santo Antônio do Pinhal é uma estância pioneira no turismo rural, muito visitada para a realização de esportes de montanha. Historicamente, a região foi desbravada por volta de 1720, pelos Bandeirantes. Em 1860, foi fundado oficialmente o povoado, dando-se a ele o nome de Santo Antônio do Pinhal em razão dos muitos pinheiros (Araucária angustifólia) existentes no local. 
Os solos do município, em quase sua totalidade, correspondem à classe Latossolo Vermelho Escuro com intrusões de Cambissolo Háplico (Kurkdijan et al., 1992). A área agricultável representa cerca de 690 ha em que aproximadamente 140 ha são culturas perenes, 110 ha semiperene e 450 ha de culturas anuais (LUPA, 1996). Segundo essa mesma fonte, o município apresenta: 5.610 ha em pastagens, 380 ha em reflorestamento e 2.160 ha de vegetação natural. Predominam no município as pequenas propriedades: 333 entre 0-50 ha, 49 entre 50-500 ha e nenhuma acima de 500 ha (LUPA, 1996). Segundo o IBGE (2000), a população rural em 2000 era de 3.297 indivíduos, enquanto a urbana era apenas de 3.031, o município situa-se na porção norte do cone leste paulista, próximo a Campos do Jordão e nas divisas com o Estado de Minas Gerais (Figura 1).

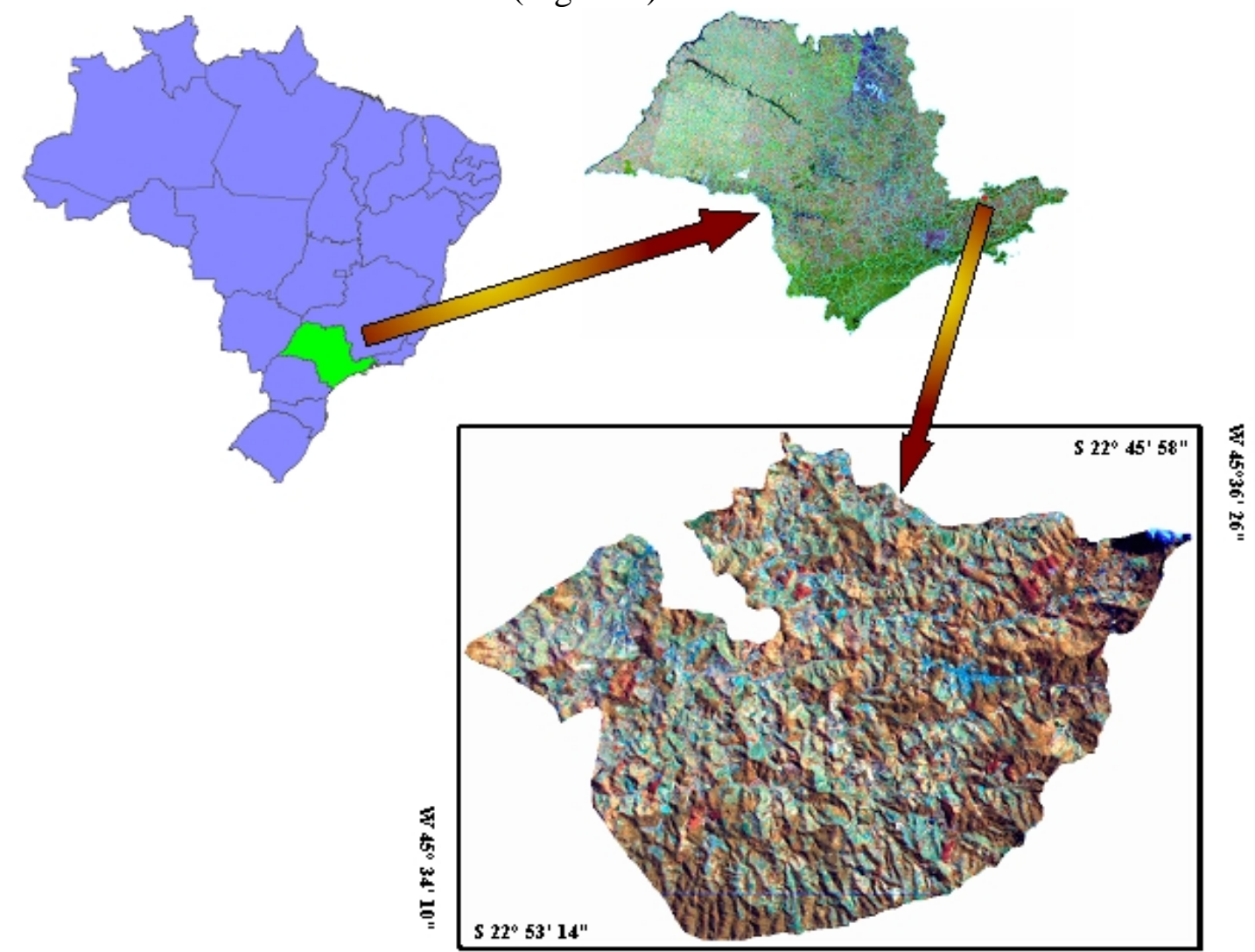

Figura 1. Localização da área de estudo correspondente aos limites do município de Santo Antônio do Pinhal em relação ao Brasil e Estado de São Paulo.

\subsection{Geração do Mapa de Áreas de Preservação Permanente}

\subsubsection{Fundamentação Legal}

A metodologia utilizada para execução do Mapeamento de Áreas Protegidas, em especial as Áreas de Preservação Permanente (APPs), foi baseada na Lei Federal Nº 4.771, de 1965 que instituiu o Código Florestal Brasileiro e nas Resoluções CONAMA No 04/1985 e N ${ }^{\text {os }} 302$ e 303/2002. De acordo com os critérios estabelecidos na legislação, as áreas protegidas foram mapeadas seguindo metodologia específica para cada uma das classes descritas na Resolução CONAMA 303/2002, transcrita a seguir e conforme Oliveira et al. (2006):

Art. $3^{\circ}$ Constitui Área de Preservação Permanente a área situada:

I - em faixa marginal, medida a partir do nível mais alto, em projeção horizontal, com largura mínima, de:

a) trinta metros, para o curso d água com menos de dez metros de largura; 
b) cinqüenta metros, para o curso d’água com dez a cinqüenta metros de largura;

c) cem metros, para o curso d’água com cinqüenta a duzentos metros de largura;

d) duzentos metros, para o curso d’água com duzentos a seiscentos metros de largura;

e) quinhentos metros, para o curso d’água com mais de seiscentos metros de largura;

II - ao redor de nascente ou olho d’água, ainda que intermitente, com raio mínimo de cinqüenta metros de tal forma que proteja, em cada caso, a bacia hidrográfica contribuinte;

III - ao redor de lagos e lagoas naturais, em faixa com metragem mínima de:

a) trinta metros, para as que estejam situados em áreas urbanas consolidadas;

b) cem metros, para as que estejam em áreas rurais, exceto os corpos d água com até vinte hectares de superfície, cuja faixa marginal será de cinqüenta metros;

IV - em vereda e em faixa marginal, em projeção horizontal, com largura mínima de cinqüenta metros, a partir do limite do espaço brejoso e encharcado;

V - no topo de morros e montanhas, em áreas delimitadas a partir da curva de nível correspondente a dois terços da altura mínima da elevação em relação à base;

VI - nas linhas de cumeada, em área delimitada a partir da curva de nível correspondente a dois terços da altura, em relação à base, do pico mais baixo da cumeada, fixando-se a curva de nível para cada segmento da linha de cumeada equivalente a mil metros;

VII - em encosta ou parte desta, com declividade superior a cem por cento ou quarenta e cinco graus na linha de maior declive;

VIII - nas escarpas e nas bordas dos tabuleiros e chapadas, a partir da linha de ruptura em faixa nunca inferior a cem metros em projeção horizontal no sentido do reverso da escarpa;

IX - nas restingas:

a) em faixa mínima de trezentos metros, medidos a partir da linha de preamar máxima;

b) em qualquer localização ou extensão, quando recoberta por vegetação com função fixadora de dunas ou estabilizadora de mangues;

$\mathrm{X}$ - em manguezal, em toda a sua extensão;

XI - em duna;

XII - em altitude superior a mil e oitocentos metros, ou, em estados que não tenham tais elevações, a critério do órgão ambiental competente;

XIII - nos locais de refúgio ou reprodução de aves migratórias;

XIV - nos locais de refúgio ou reprodução de exemplares da fauna ameaçadas de extinção que constem de lista elaborada pelo Poder Público Federal, Estadual ou Municipal;

XV - nas praias, em locais de nidificação e reprodução da fauna silvestre.

Parágrafo único. Na ocorrência de dois ou mais morros ou montanhas cujos cumes estejam separados entre si por distâncias inferiores a quinhentos metros, a Área de Preservação Permanente abrangerá o conjunto de morros ou montanhas, delimitada a partir da curva de nível correspondente a dois terços da altura em relação à base do morro ou montanha de menor altura do conjunto, aplicando- se o que segue:

I - agrupam-se os morros ou montanhas cuja proximidade seja de até quinhentos metros entre seus topos. 


\subsubsection{Tratamento Prévio dos Dados de Base}

A utilização de um SIG (Sistema de Informações Geográficas) para efetuar o mapeamento de áreas protegidas requer o tratamento prévio de camadas de informações geográficas, contendo os dados topográficos de planimetria, altimetria, declividade, rede de drenagem, corpos d’água e divisores topográficos de bacias (linhas de cumeada). Essas informações foram inseridas no banco de dados por meio da vetorização de cartas topográficas na escala de 1:50.000, contendo as curvas de nível com eqüidistância vertical de $20 \mathrm{~m}$ e a rede de drenagem. Esses dados foram processados, para se gerar uma grade triangular TIN (Triangular Irregular Network), utilizando-se a rede de drenagem correspondente como linhas de quebra. A partir da grade triangular resultante, foi gerada uma grade regular com resolução espacial de $20 \mathrm{~m}$, que assegura uma coordenada $3 \mathrm{D}$ a cada célula de $400 \mathrm{~m}^{2}$, caracterizando assim o MDT (Modelo Digital do Terreno) de todo o município. A partir da rede de drenagem foram gerados mapas de distância em metros, com valor 0 (zero), partindo da linha vetorial correspondente à rede de drenagem e dos pontos correspondentes às nascentes, esses inseridos no ponto inicial à montante de cada linha de drenagem. As linhas de cumeada foram geradas por meio da interpretação dos divisores topográficos pelo delineamento das curvas de nível, e traçadas em camada vetorial específica no banco de dados. Com a utilização da grade MDT gerada com base nos dados altimétricos, foram geradas grades de declividade da qual foram extraídos uma classe de APP (declividade $>45^{\circ}$ ) e um dado de apoio à delimitação de Topo de Morro, (Declividade > ou = a 30\%). A partir desse tratamento prévio dos dados, torna-se possível o Mapeamento das Áreas Protegidas, utilizando-se metodologia específica para cada uma das classes de APPs. (Aulicino et al., 2000).

A alternativa do uso de dados do Shuttle Radar Topography Mission (SRTM), no lugar das cartas topográficas 1:50.000, embora com vantagens operacionais, não seria viável para a escala de trabalho (nível municipal) devido à restrição da resolução espacial dos dados hoje disponíveis (Hott et al., 2005).

\subsection{Mapeamento de Áreas de Preservação Permanente (APP)}

\subsubsection{Mapeamento de APPs de Margens de Rios}

O mapeamento das APPs de margens de rios foi obtido por meio do mapa de distâncias da rede de drenagem, gerado com faixas de distância de 1,0m, que foi, posteriormente, fatiado com a distância de 30m (Buffer) em ambos os lados da drenagem, quando essa apresenta largura igual ou inferior a 10m, e 50m quando apresenta largura entre 10 e 50m.

\subsubsection{Mapeamento de APPs de Nascentes}

O mapeamento das APPs de entorno de nascentes foi obtido de forma semelhante ao mapeamento das APPs de Margens de Rios, porém utilizando-se como dado de entrada para a geração do mapa de distância, em metros, um plano de informação contendo somente os pontos correspondentes às nascentes. Desse plano de informações, foi gerado de forma análoga ao das margens, um mapa de distância com faixas de $1 \mathrm{~m}$ a partir de cada ponto correspondente às nascentes, esse mapa foi fatiado com valor correspondente a 50m de raio a partir do ponto central, para produzir o mapeamento da classe de APP de Nascentes.

\subsubsection{Mapeamento de APPs de Declividade Superior a $45^{\circ}$ ou $100 \%$}

A partir da grade do Modelo Digital do Terreno, previamente trabalhada como dado de base, foi gerada uma grade de declividade em graus, que foi, posteriormente, fatiada, gerando 
um mapa temático em que as áreas cuja declividade apresentou valores iguais ou superiores a $45^{\circ}$ ou $100 \%$ foram atribuídas à classe APPs de inclinação superior a 45 graus.

\subsubsection{Mapeamento de APPs de Topo de Morro e linha de cumeada}

O mapeamento de APPs de topo de morro (montes, serras e montanhas) e linha de cumeada depende de um aparato de apoio para a caracterização do relevo e a tomada dos pontos de cume e base de morro necessários ao cálculo do terço superior, que corresponde à área de preservação propriamente dita. Nesse contexto, foi necessária a criação de planos de informação, contendo em separado, Linhas de Cumeada, Grade Regular de Altimetria, Declividade igual ou superior a 30\%, Rede de Drenagem, Curvas de Nível e ainda um plano de informação vetorial criado especialmente para receber os polígonos correspondentes à classe Topo de Morro e linha de cumeada. Essa metodologia está de acordo com procedimentos da Secretaria do Meio Ambiente, Coordenadoria de Licenciamento Ambiental e Proteção de Recursos Naturais, Departamento Estadual de Proteção de Recursos Naturais (Oliveira et al., 2006).

Considerando-se os itens que devem ser obrigatoriamente observados para a delimitação dos topos de morro, foram então traçadas as curvas de nível que correspondem à delimitação do terço superior, delimitando-se assim a Área de Preservação Permanente de Topo de Morro e Linha de Cumeada. A interpretação dos morros, agrupamentos de morros ou ainda cadeia de morros e montanhas, levou em consideração a Resolução CONAMA n 303/2002, especificamente para esta classe de APP, como segue:

$\mathrm{V}$ - no topo de morros e montanhas, em áreas delimitadas a partir da curva de nível correspondente a dois terços da altura mínima da elevação em relação à base;

VI - nas linhas de cumeada, em área delimitada a partir da curva de nível correspondente a dois terços da altura, em relação à base, do pico mais baixo da cumeada, fixando-se a curva de nível para cada segmento da linha de cumeada equivalente a mil metros;

A mesma resolução estabelece ainda critérios para a caracterização do relevo para a delimitação dessa classe de APPs como segue:

IV - morro: elevação do terreno com cota do topo em relação à base entre cinqüenta e trezentos metros e encostas com declividade superior a trinta por cento (aproximadamente dezessete graus) na linha de maior declividade;

V - montanha: elevação do terreno com cota em relação à base superior a trezentos metros;

VI - base de morro ou montanha: plano horizontal definido por planície ou superfície de lençol d’água adjacente ou, nos relevos ondulados, pela cota da depressão mais baixa ao seu redor;

VII - linha de cumeada: linha que une os pontos mais altos de uma seqüência de morros ou de montanhas, constituindo-se no divisor de águas.

\subsection{Mapa de Áreas de Preservação Permanente}

Os dados obtidos individualmente no mapeamento de cada classe de APP foram, posteriormente, agrupados em um único plano de informação, obedecendo a uma ordem de prioridade arbitrária, convencionada pelos autores como ordem de importância decrescente, com a seguinte disposição das classes, $1^{\circ}$ Nascentes, $2^{\circ}$ Margens de Rios e Corpos D'Água, $3^{\circ}$ Declividade Superior a 45 graus ou $100 \%$, $4^{\circ}$ Altitude Superior a $1800 \mathrm{~m}$ e $5^{\circ}$ Topos de Morro e Linhas de Cumeada. Do agrupamento dessas classes num único plano de informações, obtém-se um Mapa de Áreas de Preservação Permanente sem que exista uma sobreposição de áreas, dando origem ao mapa final de Áreas de Preservação Permanente. 


\section{RESULTADOS E DISCUSSÃO}

Com base na metodologia descrita, as Figuras 2 e 3 exemplificam o mapeamento das APPs de margens de rio.

De forma similar, as Figuras 4 e 5 exemplificam o resultado do mapeamento de APPs de nascentes.

A Figura 6 mostra a grade regular das cotas altimétricas correspondentes ao Modelo Digital do Terreno, gerada no software SPRING e a Figura 7 exemplifica o resultado do mapeamento da APP de declividade.

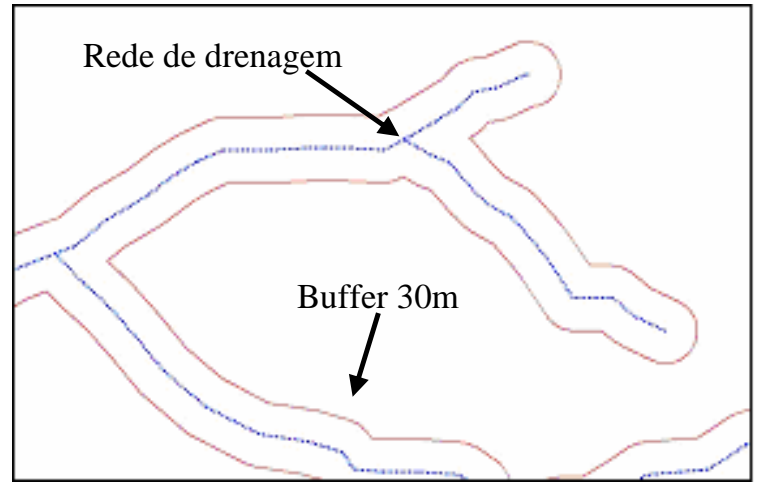

Figura 2. Exemplo da vetorização da rede de drenagem e geração do mapa de distância, com delimitação de 30m a partir das margens dos rios no SPRING.

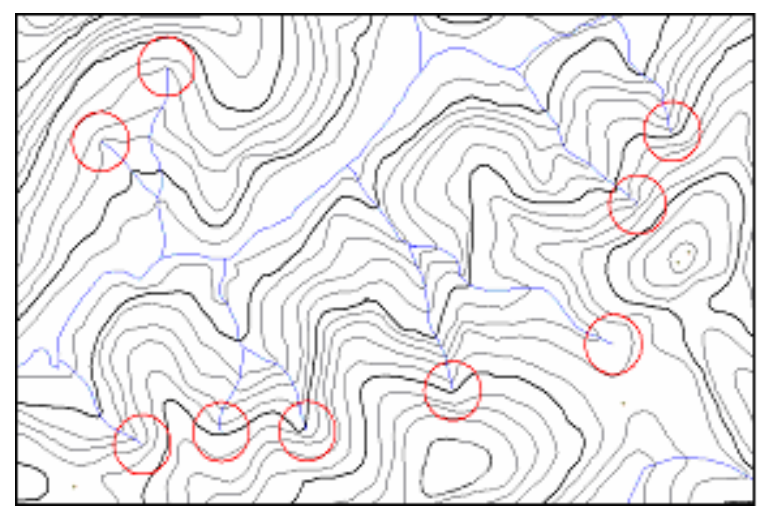

Figura 4. esemplo da delimitação de APPs de nascentes com raio de 50m no SPRING.

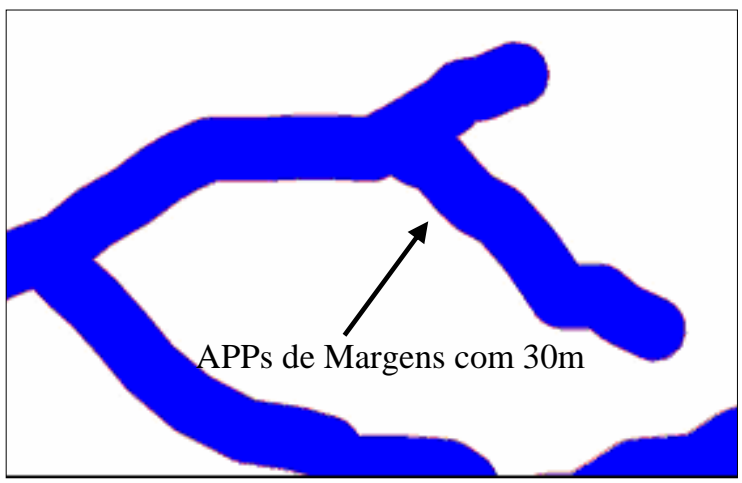

Figura 3. Exemplo de mapeamento de APP de margens de rios com faixa de 30m no SPRING.

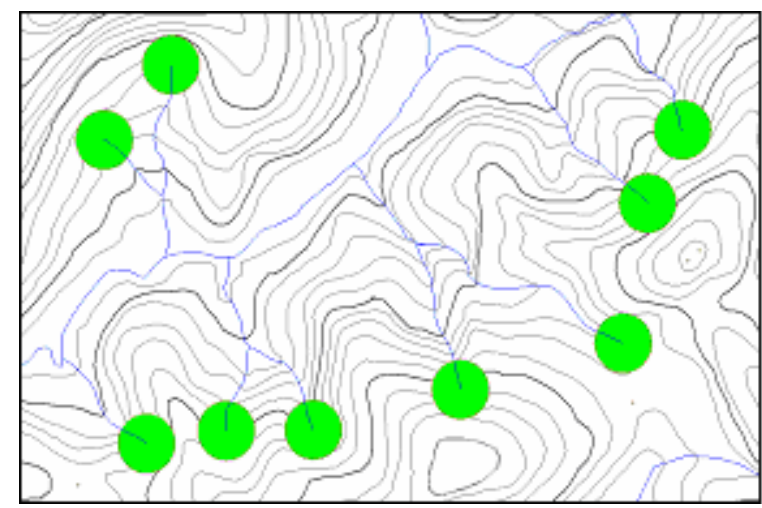

Figura 5. Exemplo do mapeamento de APPs de nascentes com raio de 50m no SPRING.

A Figura 8 apresenta um conjunto de detalhes de interpretação da classe de APP Topo de Morros utilizando-se o SPRING na versão 4.2.

A Figura 9 mostra um detalhe ampliado do mapeamento de todas as classes de APPs que ocorrem no município, exceto a APP de altitude maior que $1800 \mathrm{~m}$.

Os resultados obtidos da classificação das diversas classes de APPs (Figura 9) na execução deste trabalho levaram em consideração as definições de APPs previstas em Leis Federais, há que se ressaltar que os Estados e Municípios, por meio de seus órgãos ambientais responsáveis, têm competência para estabelecer normas e procedimentos mais restritivos. Portanto, as áreas de APPs, se avaliadas com base nas legislações estadual e municipal, poderão aumentar em função dessas restrições adicionais. 
CATELANI, C. S.; BATISTA, G. T. Mapeamento das Áreas de Preservação Permanente (APP) do município de Santo Antônio do Pinhal, SP: um subsídio à preservação ambiental. Ambi-Agua, Taubaté, v. 2, n. 1, p. 30-43, 2007. (doi:10.4136/ambi-agua.18)

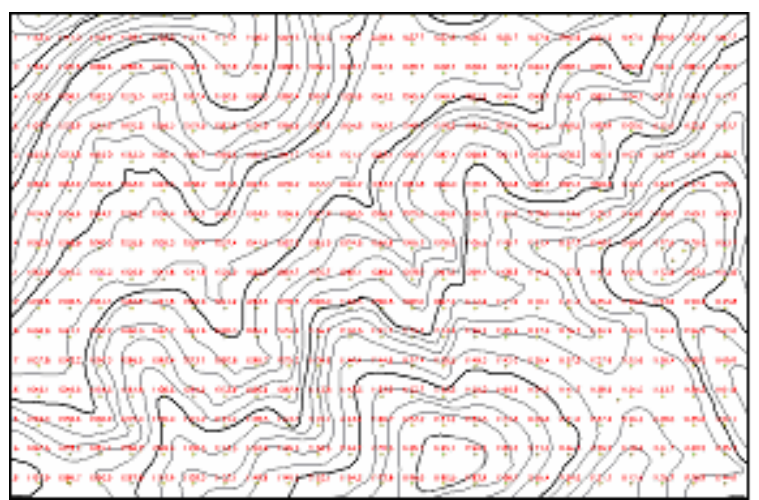

Figura 6. Detalhe da Grade Regular do Modelo Digital do Terreno no SPRING.

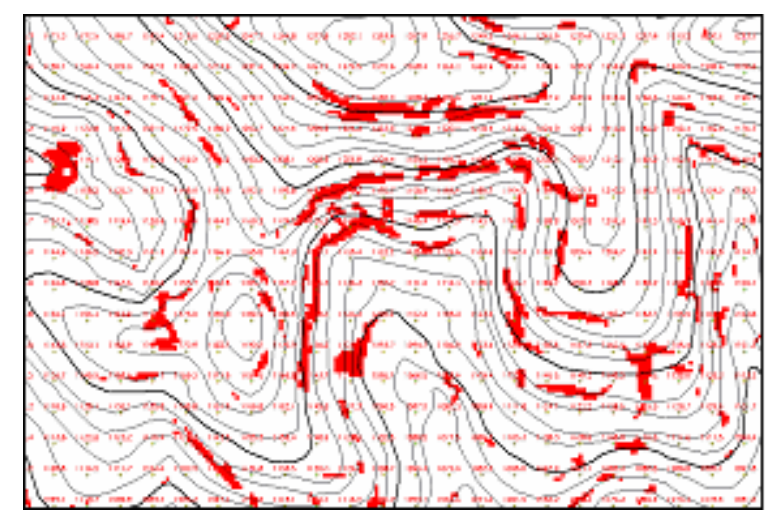

Figura 7. Exemplo do mapeamento de APPs de declividade superior a 45 graus no SPRING.

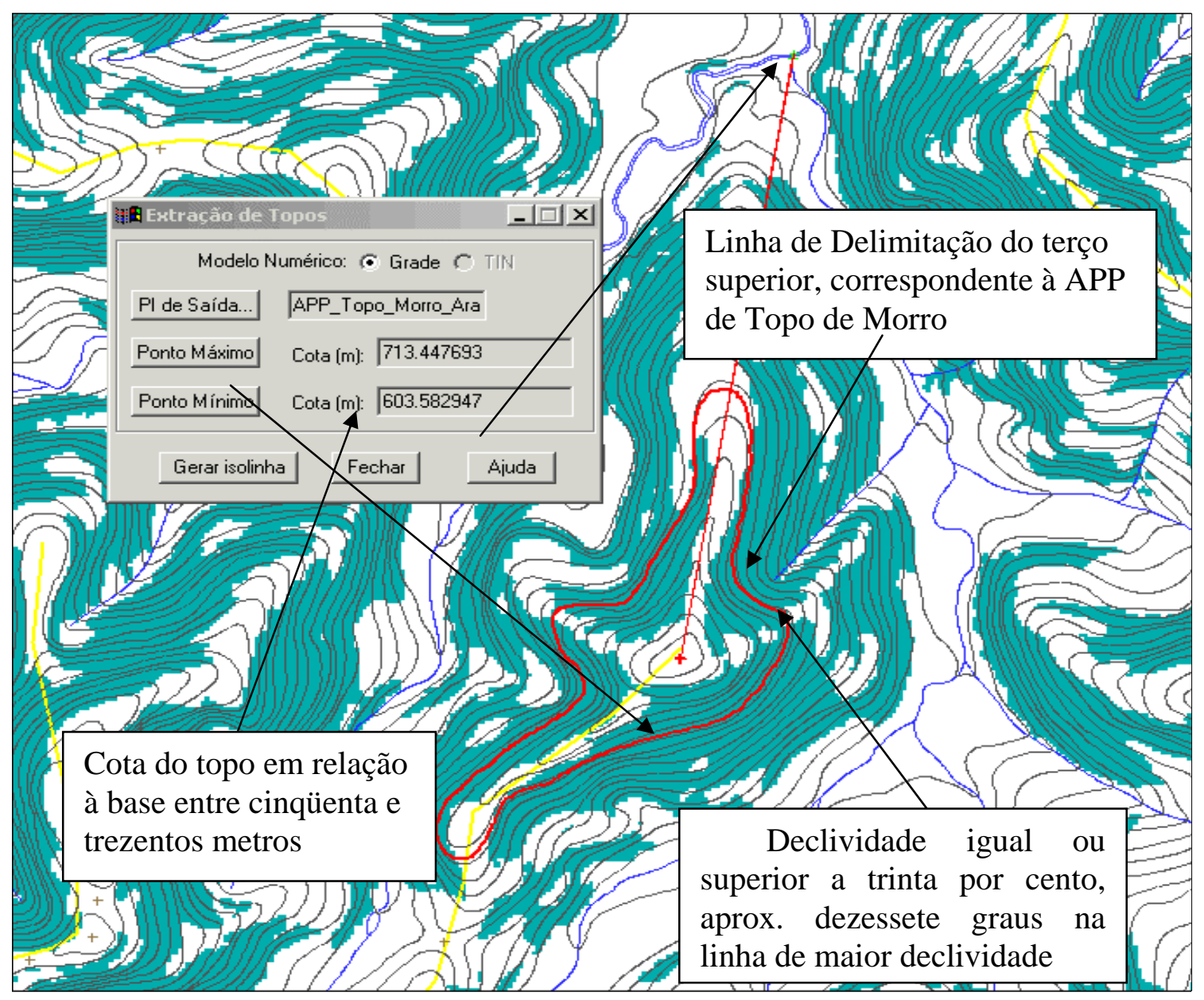

Figura 8. Detalhes dos elementos avaliados na interpretação da classe de APP de Topo de Morros, utilizando-se o software SPRING (Câmara et al., 1996).

Há que se considerar também, em adição, as áreas de reserva legal que correspondem a 20\% da área das propriedades rurais nesse município. É bom salientar ainda que as informações de APPs de topo de morro encontram-se no ponto de maior complexidade tanto no entendimento de seus limites reais e legais, quanto na sua delimitação espacial (Moreira et al., 2003). 
Em consonância com os objetivos deste trabalho, foram mapeadas as classes de APPs, na escala de 1:50.000 (Figura 10), e as áreas de cada classe de APP são apresentadas na (Tabela 1). Pode-se notar que a classe Topo de Morros ocupa uma área de 4.227 ha equivalentes a 30,7\% do total do município, isso demonstra claramente a importância dessa classe de APP em relação às demais. Esse fato foi também evidenciado por outros autores em análises semelhantes (Nascimento et al., 2005, Ribeiro et al., 2005) o que leva a uma reflexão sobre a importância dessa classe de APP, especialmente, no domínio geomorfológico dos mares de morros, onde se insere este município e onde a tradição de uso do solo é tipicamente conflitante com a necessidade de preservação.

Mapeamentos, como os apresentados neste artigo, são essenciais para a gestão municipal, especialmente, para subsidiar o plano diretor, uma vez que essas áreas têm restrição legal de uso.

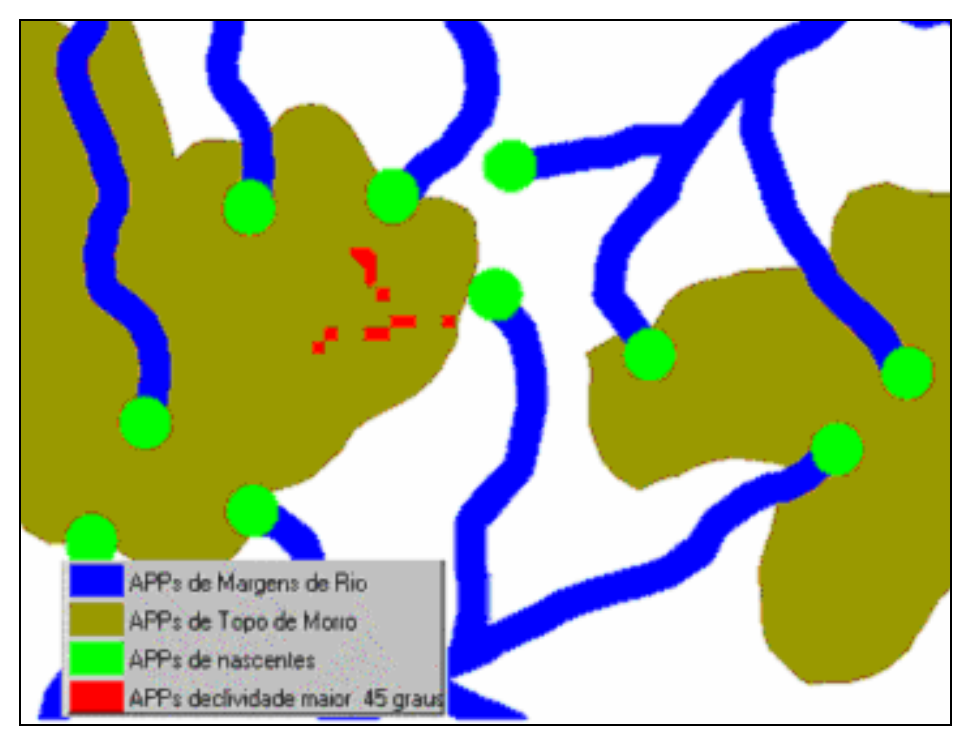

Figura 9. Exemplo dos polígonos temáticos resultantes do mapeamento das Áreas de Preservação Permanente do Município de Santo Antônio do Pinhal, SP.

Embora haja propostas de delimitação de APPs de topo de morro de forma automatizada (Hott et al., 2005; Ribeiro et al., 2002, 2005), ferramentas disponíveis no SPRING foram funcionais para a determinação dessa classe de APP, uma vez que essa operação envolve aspectos interpretativos da legislação que dependem de situações localizadas. 
CATELANI, C. S.; BATISTA, G. T. Mapeamento das Áreas de Preservação Permanente (APP) do município de Santo Antônio do Pinhal, SP: um subsídio à preservação ambiental. Ambi-Agua, Taubaté, v. 2, n. 1, p. 30-43, 2007. (doi:10.4136/ambi-agua.18)

Tabela 1. Área das classes de Áreas de Preservação Permanente do Município de Santo Antônio do Pinhal.

\section{Área das APPs}

\begin{tabular}{lrcc}
\hline \multicolumn{1}{c}{ Classes de APPs } & Área (ha) & \% das APPs & \% das APPs no Município \\
\hline Nascentes & 328 & 4,6 & 2,4 \\
Margens (30m) & 2585 & 35,8 & 18,8 \\
Inclinação > 45 & 24 & 0,3 & 0,2 \\
Altitude > 1800m & 41 & 0,7 & 0,3 \\
Topos de Morros & 4227 & 58,6 & 30,7 \\
\hline TOTAL de APPs & $\mathbf{7 2 1 8}$ & $\mathbf{1 0 0 , 0}$ & $\mathbf{5 2 , 3}$ \\
\hline
\end{tabular}

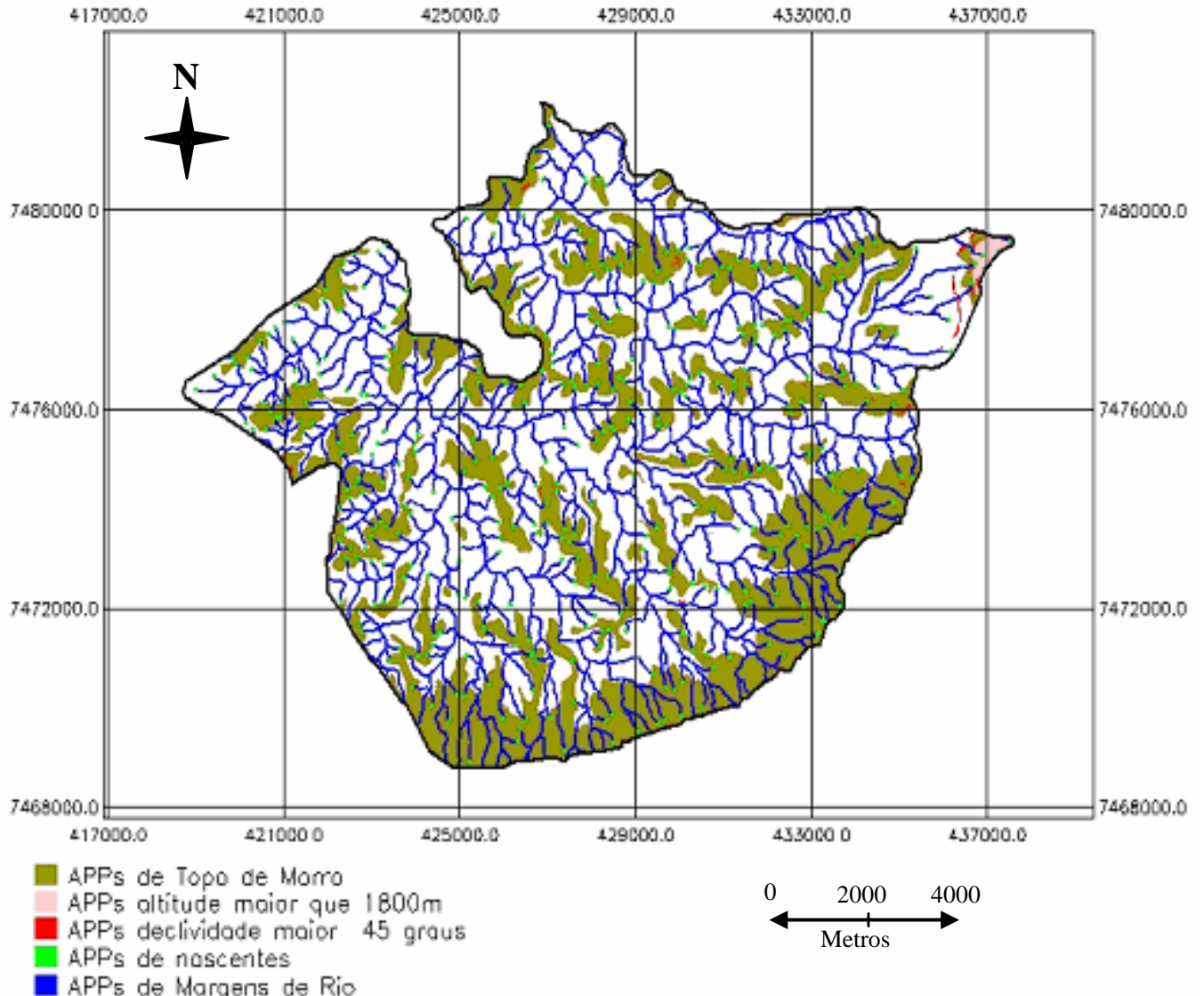

Figura 10. Mapa das Áreas de Preservação Permanente (APPs) do município de Santo Antônio do Pinhal, SP. 


\section{CONCLUSÕES}

A partir dos estudos realizados neste trabalho, pôde-se chegar às seguintes conclusões:

O município de Santo Antônio do Pinhal apresenta na escala de trabalho de 1:50.000 um total de 7.218 ha de áreas de preservação permanente (APPs) o que equivale a 52,3\% da área do município;

A determinação de APPs referentes aos topos de morros, montes, serras e montanhas requerem grande esforço interpretativo do analista e, portanto, recomenda-se precaução no uso dos resultados referentes a essa classe;

O mapa de APPs é fortemente dependente da escala de trabalho e resolução da grade do modelo numérico do terreno usado na delimitação dessas áreas. Portanto, os resultados aqui reportados se referem à escala de trabalho de 1:50.000, em que foram utilizadas curvas de nível com eqüidistância vertical de 20m e grade regular de MNT também com 20m de resolução;

Para delimitação de áreas de APP do município é fundamental trabalhar com o modelo digital do terreno e rede de drenagem além dos limites municipais, pois a linha de base para a delimitação dos topos de morro pode estar fora do município;

A espacialização dos limites das classes de APPs de Topo de Morro e linhas de cumeada é subjetiva e, portanto, objeto de interpretação;

Ferramentas de sistemas de informação geográfica (SIGs) como as disponíveis no software SPRING foram essenciais para a verificação e mapeamento de áreas de preservação permanente ao nível municipal ou regional.

\section{REFERÊNCIAS}

AULICINO, L. C. M.; RUDORFF, B. F. T.; MOREIRA, M. A.; MEDEIROS, J. S.; SIMI JR., R. Subsídios para o manejo sustentável da bacia hidrográfica do rio Una através de técnicas de geoprocessamento e de sensoriamento remoto. In: SIMPÓSIO LATINOAMERICANO DE PERCEPCIÓN REMOTA, 9., 2000, Puerto Iguazu. Memórias... . Lujan: SELPER, 2000. p. 899-908.

BRASIL. Decreto-lei no 4.771, de 15 de setembro de 1965. Institui o Novo Código Florestal Brasileiro e dá outras providências. Diário Oficial da União DOU de 16 de setembro de 1965. Brasília DF. 1965.

BRASIL. Conselho Nacional do Meio Ambiente. Resolução nº 4, de 18 de setembro de 1985. Tendo em vista o que estabelece a Lei 4.771, de 15 de setembro de 1965, alterada pela lei 6.535, de 15 de junho de 1978, e pelo que determina a Resolução CONAMA 008/84 estabelece critérios para as Áreas de Preservação Permanente. Diário Oficial da União DOU de 20 de janeiro de 1986. Brasília DF, 1986.

BRASIL. Conselho Nacional do Meio Ambiente. Resolução nº 303, de 20 de março de 2002. Dispõe sobre parâmetros, definições e limites de Áreas de Preservação Permanente. Diário Oficial da União DOU de 13 de maio de 2002. Brasília DF, 2002.

BRASIL. Ministério do Planejamento, Orçamento e Gestão. Instituto Brasileiro de Geografia e Estatística. Censo demográfico 2000. Rio de Janeiro: IBGE, 2000. p. 1-520. 
BRASIL. Ministério do Planejamento, Orçamento e Gestão. Instituto Brasileiro de Geografia e Estatística. Superintendência de Cartografia. Carta Tremembé (SP): SF 23-Y-B-V-4. 1974. In:__ Carta do Brasil. Rio de Janeiro: IBGE, 1974. Escala 1:50.000. Projeção Universal Transversa de Mercator.

BRASIL. Ministério do Planejamento, Orçamento e Gestão. Instituto Brasileiro de Geografia e Estatística. Superintendência de Cartografia. Carta Monteiro Lobato (SP-MG): SF-23Y-B-V-3, 1973. In: Carta do Brasil. Rio de Janeiro: IBGE, 1973. Escala 1:50.000. Projeção Universal Transversa de Mercator.

BRASIL. Ministério da Ciência \& Tecnologia. Convenção sobre mudança do clima: o Brasil e a Convenção Quadro das Nações Unidas. Brasília: MCT, 2002. Disponível em: <http://www.mct.gov.br/index.php/content/view/3888.html>. Acesso em 10 abr. 2006.

CÂMARA, G.; SOUZA, R. C. M.; FREITAS, U. M.; GARRIDO, J. SPRING: Integrating remote sensing and GIS by object-oriented data modelling. Computers \& Graphics, Amsterdam , v. 20, n. 3, p. 395-403, may-jun 1996.

COSTA, T.; COSTA, C.; SOUZA, M. G.; BRITES, R. S. Delimitação e caracterização de áreas de preservação permanente por meio de um sistema de informações geográficas (SIG). Revista Árvore, Viçosa, v. 20, n. 1, p. 129-135, 1996.

HOTT, M. C.; GUIMARÃES, M. M.; MIRANDA, E. E. Um método para a determinação automática de áreas de preservação permanente em topos de morros para o Estado de São Paulo. In: SIMPÓSIO BRASILEIRO DE SENSORIAMENTO REMOTO, 12., 16-21 abril 2005, Goiânia. Anais... Goiânia: INPE, 2005. p. 3061-3068.

KRONKA, F. J. N.; NALON, M. A.; MATSUKUMA, C. K.; KANASHIRO, M. M.; YWANE, M. S. S. I.; LIMA, L. M. P. et al. Monitoramento da vegetação natural e do reflorestamento no Estado de São Paulo. In: SIMPÓSIO BRASILEIRO DE SENSORIAMENTO REMOTO, 12., 16-21 abril 2005, Goiânia. Anais... São José dos Campos: INPE, 2005. p. 1569-1576.

KURKDJIAN, M. L. N. O.; VALÉRIO FILHO, M.; VENESIANI, P.; PEREIRA, M. N.; FLORENZANO, T. G.; ANJOS, C. E. dos et al. Macrozoneamento da Região do Vale do Paraíba e Litoral Norte do Estado de São Paulo. São José dos Campos: INPE, 1992. 176 p. (INPE-5381- PRP/165).

MIGUEZ, J. D. G. O mecanismo de desenvolvimento limpo: a proposta e as perspectivas brasileiras. In: ENCONTRO: SUSTENTABILIDADE NA GERAÇÃO E USO DE ENERGIA NO BRASIL: OS PRÓXIMOS VINTE ANOS, 18-20 fev. 2002, Campinas. Anais... Campinas: UNICAMP, 2002. Disponível em: http://libdigi.unicamp.br Acesso em 22 maio. 2006.

MOREIRA, A. A.; SOARES, V. P.; RIBEIRO, J. C.; RIBEIRO, C. A. A. S.. Determinação de áreas de preservação permanente em uma microbacia hidrográfica a partir de fotografias aéreas de pequeno formato. In: SIMPÓSIO BRASILEIRO DE SENSORIAMENTO REMOTO, 11., 5-10 abr. 2003, Belo Horizonte. Anais... São José dos Campos: INPE, 2003. p. 1381 - 1389. CD-ROM, On-line. Publicado como: INPE--PRE/. Disponível em: <http://marte.dpi.inpe.br:80/rep-/ltid.inpe.br/sbsr/2002/11.12.11.06>. Acesso em 05 abr. 2006. 
NASCIMENTO, M. C.; SOARES, V. P.; RIBEIRO, C. A. A. S.; SILVA, E. Delimitação automática de áreas de preservação permanente (APP) e identificação de conflito de uso da terra na bacia hidrográfica do rio Alegre. In: SIMPÓSIO BRASILEIRO DE SENSORIAMENTO REMOTO, 12., 16-21 abr. 2005, Goiânia. Anais... São José dos Campos: INPE, 2005. p. 2289-2296. CD-ROM, On-line. Disponível em: <http://marte.dpi.inpe.br:80/rep-/ltid.inpe.br/sbsr/2004/10.18.18.26>. Acesso em 05 abr. 2006.

OLIVEIRA, I. S.; BATISTA, G. T., CATELANI, C. S.. Minicurso: Área de Preservação Permanente (APP). In: ENCONTRO ÁGUA \& FLORESTA, 7-9 nov. 2006, Taubaté. Repositório Eletrônico Ciências Agrárias. Taubaté: UNITAU, 2006. 78p. (Coleção Ciências Florestais). Disponível em: <http://hdl.handle.net/2315/66>. Acesso em 27 mar. 2007).

PINCINATO, F. L. Sensoriamento remoto e SIG na análise da viabilidade de recuperação de áreas de preservação permanente irregulares em São Sebastião - SP. In: SIMPÓSIO BRASILEIRO DE SENSORIAMENTO REMOTO, 12., 16-21 abr. 2005, Goiânia. Anais... Goiânia: INPE, 2005. p. 2323-2330.

REBOUÇAS, A. C.; BRAGA, B.; TUNDISI, J. G. Águas doces no Brasil: capital ecológico, uso e conservação. São Paulo: Escrituras, 1999. 717 p.

RIBEIRO C. A. A. S.; SOARES, V. P.; OLIVEIRA, A. M. S.; GLERIANI, J. M.O. Desafio da delimitação de áreas de preservação permanente. Revista Árvore, Viçosa, v. 29, n. 2, p. 203-212, 2005.

RIBEIRO, C. A. A. S.; OLIVEIRA, M. J. de; SOARES, V. P.; PINTO, F. de A. de C. Delimitação automática de áreas de preservação permanente em topos de morro e em linhas de cumeada: metodologia e estudo de caso. In: SEMINÁRIO DE ATUALIZAÇÃO EM SENSORIAMENTO REMOTO E SISTEMAS DE INFORMAÇÕES GEOGRÁFICAS APLICADOS À ENGENHARIA FLORESTAL, 5., 2002, Curitiba. Anais... Curitiba: FUPEF, 2002.

SAITO, M. A. Manejo de pastagens: recursos naturais: caracterização e conservação. Campinas: Instituto Agronômico de Campinas, 1995. 143 p. cap. 1.

SÃO PAULO (Estado). Coordenadoria de Assistência Técnica Integral. Centro de Informações agropecuárias. Levantamento das unidades de produção agropecuária: estatísticas agrícolas - Estado de São Paulo 1995/96. Campinas, 1996. Disponível em: <http://www.cati.sp.gov.br/servicos/lupa/m_lupa.htm>. Acesso em 14 mar 2006.

VICTOR, M. A. M. A devastação florestal em São Paulo. São Paulo. Sociedade Brasileira de Silvicultura, 1979. 48p. 


\begin{tabular}{|c|} 
ISSN = 1980-993X - doi:10.4136/1980-993X \\
www.agro.unitau.br/ambi-agua \\
E-mail: ambi-agua@agro.unitau.br \\
Tel.: (12) 3625-4116
\end{tabular}

\title{
Escoamento superficial na bacia hidrográfica do Ribeirão Itaim (doi:10.4136/ambi-agua.19)
}

\author{
Luiz Sérgio Gonçalves Aguiar; Marcelo dos Santos Targa; \\ Getulio Teixeira Batista
}

\begin{abstract}
Programa de Pós-Graduação em Ciências Ambientais da Universidade de Taubaté
\end{abstract} E-mail: aguiar.agro@gmail.com; \{mtarga; getulio\}@agro.unitau.br

\section{RESUMO}

Este trabalho realizado, na bacia hidrográfica do ribeirão Itaim, município de Taubaté, $\mathrm{SP}$, visou estimar o escoamento superficial pelo método Curva-Número (CN) em área com cobertura vegetal de Brachiaria Decumbens, que é predominante na bacia. Valores do CN foram definidos em função do uso e cobertura do solo. O escoamento superficial (Q) foi estimado por três métodos: $1^{\circ}$ ) utilizaram-se-se valores de infiltração acumulada (IAc) obtidos no campo, considerados como Infiltração Potencial (S), os quais variaram de 15,37 mm a $51,88 \mathrm{~mm}$ com um valor médio de 23,46 mm. Com esses valores de infiltração e utilizando-se valores de precipitações máximas para Taubaté, SP, com tempo de duração de 3 horas: $\mathrm{P}=$ 54,4; 70,3; 80,8; 86,7; 90,9; 94,1 e 103,9 mm, respectivamente, para os tempos de retorno de $\operatorname{Tr}=2$, 5, 10, 15, 25, 50 e 100 anos, os seguintes valores de (Q) foram obtidos: 34,83; 49,33; 59,14; 64,71; 68,69; 71,73 e 81,10 mm, respectivamente; $2^{\circ}$ ) considerou-se a predominância de Pasto Sujo na bacia e utilizando-se o valor adimensional $C N=75$, obteve-se $S=84,7 \mathrm{~mm}$ e chegou-se aos valores de (Q) que variaram de 11 a $44 \mathrm{~mm} ; 3^{\circ}$ ) considerou-se o valor ponderado para todas as classes de uso da bacia, $\mathrm{CN}_{\text {ponderado }}=66,57$, e obteve-se um valor mais elevado para infiltração potencial, $\mathrm{S}=127 \mathrm{~mm}$. Conseqüentemente, os resultados dos valores de (Q) foram mais baixos e corresponderam a 5,33; 11,64; 16,72; 19,83; 22,16; 23,98 e 29,83 mm, respectivamente. Dessa forma, concluiu-se que o método CN (tanto para a classe predominante quanto para o ponderado) subestimou o escoamento superficial na área estudada. Entretanto, é possível sua utilização desde que se promovam os ajustes para as situações locais com base em medidas prévias de infiltração em campo.

Palavras-chave: escoamento superficial; infiltração; curva-número; infiltrômetro de anéis; bacia hidrográfica.

\section{Surface runoff in the Itaim Watershed}

\section{ABSTRACT}

This paper describes a work done in the Itaim watershed at Taubaté, SP, and had the objective of estimating the surface runoff based on the Curve-Number (CN) method in area with vegetation cover of grassland (Brachiaria Decumbens), that prevails in this watershed. The surface runoff was estimated using three different methods: $1^{\text {st }}$ ) values of accumulated Infiltration (IAc) obtained in the field were used, considered as the Potential Infiltration (S), which varied from $15.37 \mathrm{~mm}$ to $51.88 \mathrm{~mm}$ with an average value of $23.46 \mathrm{~mm}$. With those measured infiltration rates and using the maximum precipitation values for Taubaté, SP, with duration time of 3 hours: $\mathrm{P}=54.4$; 70.3; 80.8; 86.7; 90.9; 94.1 and $103.9 \mathrm{~mm}$, respectively, for the return times, $\operatorname{Tr}=2,5,10,15,25,50$ and 100 years, the following values of surface runoff were generated: 34.83; 49.33; 59.14; 64.71; 68.69; 71.73 and $81.10 \mathrm{~mm}$, respectively; In the $2^{\text {nd }}$ method it was considered that the prevailing vegetation cover of the watershed was Dirty Pasture (Pasture with regrowth of natural vegetation) and therefore, a value of $\mathrm{CN}=75$ 
was used and generated a potential infiltration, $\mathrm{S}=84,7 \mathrm{~mm}$ and resulted in surface runoff values that varied from 11 to $44 \mathrm{~mm}$; In the $3^{\text {rd }}$ method, the value of CN was considered equal to 66.57. This value was calculated weighting the contribution of all land use cover classes of the watershed, and as a result a higher value of potential infiltration, $\mathrm{S}=127 \mathrm{~mm}$, was obtained. Consequently, the surface runoff values were $5.33 ; 11.64 ; 16.72 ; 19.83 ; 22.16$; 23.98 and $29.83 \mathrm{~mm}$, respectively. Therefore, the comparison with the results obtained by the two Curve-Number methods (conventional and weighted) allowed the conclusion that the Curve-Number method applied in a conventional way underestimated the surface runoff in the studied area. However, results indicate that it is possible to use this method for surface runoff estimates as long as adjustments based on potential infiltration obtained in field be are available for local situations.

Keywords: surface runoff; infiltration; curve-number; infiltrometer rings; hydrographic basin.

\section{INTRODUÇÃO}

A dinâmica de uso e ocupação do solo em bacias hidrográficas exige estudos para a compreensão dos diversos impactos provocados pela ação antrópica e estratégias adequadas para a conservação dos recursos naturais nessas áreas. Os principais impactos ocasionados por modificações no uso e cobertura do solo em bacias hidrográficas são: a redução da capacidade de infiltração, o aumento do escoamento superficial e erosão, a sedimentação dos cursos d'água, a diminuição da profundidade do leito dos cursos d'água e, conseqüentemente, o aumento de cheias e inundações (Grove et al., 1998; Centurion et al, 2001; Wendland, 2001).

Para Grove et al (1998), uma das técnicas mais amplamente utilizada para estimar o escoamento superficial é o método Curva-Número ou CN desenvolvido pelo Serviço de Conservação do Solo (SCS - USDA), atualmente denominado de Serviço de Conservação dos Recursos Naturais (NRCS-USDA). O método é empírico e baseado em um conjunto de relações entre precipitação, condições de superfície do solo e escoamento.

Segundo Braga Jr. e Conejo (1983), é importante que o escoamento superficial não seja analisado de maneira isolada e, sim, com clara compreensão de que os processos de infiltração e escoamento ocorrem simultaneamente.

Para Secco et al. (2005), o estudo dos atributos físicos do solo, tais como densidade e espaço poroso, podem ser utilizados como indicadores da qualidade do solo e refletir o manejo a que o solo está sendo submetido, o que facilita o entendimento desses processos.

Centurion et al. (2001) afirmam que a alteração de ecossistemas naturais acontece devido à implementação de atividades voltadas para fins industriais ou de produção de alimentos, o que quase sempre promove uso e manejo inadequado dos solos. Assim, a retirada da cobertura vegetal original e sua substituição por culturas propiciam o rompimento do equilíbrio entre o solo e o meio, interferindo nas condições químicas, físicas e biológicas, o que acentua os efeitos erosivos nessas áreas.

A bacia do Ribeirão Itaim sofreu, nos últimos anos, um aumento significativo da ocupação urbana e predomínio das pastagens em sua paisagem, refletindo em diminuição da infiltrabilidade da água e no aumento do escoamento superficial (Aguiar, 2004). Nesse sentido, deve-se considerar o grau de preservação da bacia e a relação existente entre a precipitação e o escoamento superficial, parâmetros importantes no estudo de bacias hidrográficas.

Segundo Wendland (2001), quando se estuda a precipitação intensa, contínua e persistente, tem-se uma boa análise sobre o impacto significativo exercido pelos recursos superficiais da água do solo, não somente de forma imediata, mas também a médio e longo 
prazo, o que denota a necessidade de informações que podem ser valorosas para o gerenciamento dos recursos hídricos. Esse tipo de informação pode ser obtida com mensurações da taxa de infiltração de água no solo.

Para Diamond e Shanley (2003), a avaliação do escoamento superficial tem adquirido importância crescente, devido aos perigos de erosão e poluição associados. Assim, determinações precisas das taxas de infiltração constituem um fator importante na previsão confiável do escoamento superficial.

O aumento da atividade humana também influi na disponibilidade hídrica das bacias, assim, é fator importante a ser analisado, pois tem provocado importantes alterações e conseqüentes impactos sobre esses ecossistemas, o que demanda planejamento ambiental, que deve contemplar não apenas os ambientes criados e alterados pelos seres humanos, mas também o ambiente natural ao seu redor (Rocha, 2000). Esse autor ressalta que a bacia hidrográfica é uma unidade natural de planejamento ambiental, o que permite, que seja o local onde esses estudos possam ser melhor avaliados.

De acordo com Tripathi et al (2003), o estudo intensivo das bacias individuais e diversificadas torna-se necessário para possibilitar o desenvolvimento de planos de administração a serem desenvolvidos e também para aplicar os resultados de uma bacia para outra com características similares. Assim, os estudos hidrológicos desenvolvidos na bacia do Ribeirão Itaim podem contribuir para nortear ações de recuperação e sustentabilidade ambiental na região, ampliando o conhecimento sobre as taxas de infiltração da água e do escoamento superficial e suas conseqüências em bacias com características similares.

Smemoe et al. (2004), ao desenvolverem o modelo de precipitação/escoamento para uma área de drenagem, observaram que uma das relações mais importantes a considerar é a determinação da quantidade de chuva que é convertida em escoamento. Assim, outros métodos têm sido idealizados, para determinar a quantidade de precipitação convertida em escoamento. Esses autores afirmam que o método Curva-Número (CN) fornece uma boa visão de como o escoamento na bacia é determinado a partir dos dados da precipitação. Muitas dessas suposições utilizadas pelo método $\mathrm{CN}$ são baseadas em observações empíricas da precipitação e do escoamento em áreas específicas. Contudo, o método do Curva Número é resultante de longa data de investigação para a estimativa do escoamento direto produzido das precipitações máximas e contou com esforços de pesquisadores (Sherman, 1942; Mockus, 1949; Andrews, 1954; Ogrosky, 1956 apud NRCS, 2004).

O objetivo deste trabalho foi o de determinar valores da taxa de infiltração de água em situações de campo, bem como fazer estimativas confiáveis do escoamento superficial e comparar os resultados com o método curva-número (convencional e ponderado) para essas estimativas. A Bacia do Ribeirão Itaim, no município de Taubaté, SP, foi escolhida para a realização destes estudos, em virtude de ser uma reserva estratégica de água para o município de Taubaté, pois é uma bacia contribuinte do Rio Una, que no passado foi responsável pelo fornecimento de mais de $70 \%$ da água para abastecimento de Taubaté.

\section{MATERIAL E MÉTODOS}

O trabalho foi conduzido na bacia hidrográfica do ribeirão Itaim que possui área de 57,7 $\mathrm{km}^{2}$ (Sbruzzi, 2004). A área de estudo tem cobertura vegetal predominante de pastagem (Brachiaria decumbens) e localiza-se na Fazenda Experimental do Departamento de Ciências Agrárias da Universidade de Taubaté (UNITAU), no município de Taubaté, SP.

O solo da área de estudo é classificado como Latossolo Vermelho Amarelo textura areno-argilosa (EMBRAPA, 1997); o relevo é ondulado e a altitude média é de 580 metros. O clima da região é CWA, segundo a classificação de Köppen, e caracteriza-se por ser quente e 
úmido no verão e frio e seco no inverno A fórmula climática de Taubaté utilizando a classificação de Thornthwaite, é $\mathrm{B}_{1} \mathrm{rB}_{3} \mathrm{a}^{\prime}$, que representa clima úmido com pequena ou nula deficiência de água, mesotérmico, com evapotranspiração potencial anual de $964 \mathrm{~mm}$ e concentração de evapotranspiração potencial no verão de 33\% (Fisch, 1999).

Neste trabalho, utilizou-se o método Curva-Número ou CN desenvolvido pelo NRCS USDA, que é considerado o método mais utilizado para a estimativa do escoamento superficial em bacias hidrográficas (Machado, 2002). O método é baseado nas seguintes equações:

$$
\begin{aligned}
& Q=\frac{(P-0,2 S)^{2}}{(P+0,8 S)} \\
& S=\frac{25400}{C N}-254
\end{aligned}
$$

em que:

Q: escoamento superficial (mm);

P: Precipitação Máxima em dado Período de Retorno (mm);

S: Infiltração Potencial (mm);

CN: Curva Número, valor adimensional tabelado.

Martinez Junior e Magni (1999) indicaram, para um tempo de duração de 3 horas em Taubaté, a ocorrência de precipitações máximas de 54,4; 70,3; 80,8; 86,7; 90,9; 94,1 e 103,9 $\mathrm{mm}$, respectivamente, para os tempos de retorno de 2, 5, 10, 15, 25, 50 e 100 anos, respectivamente.

A estimativa do escoamento superficial foi feita utilizando-se três métodos distintos:

\section{$\left.1^{\circ}\right)$ Medidas de campo}

Segundo Maheshawari (1996), os infiltrômetros de anéis são comumente utilizados para mensurações in-situ das características da infiltração. Os infiltrômetros podem ser de anel simples ou duplo, sendo o de anel duplo o preferido, porque o anel externo ajuda a prevenir o fluxo lateral, diminuindo o erro da leitura.

Mediu-se a infiltração acumulada (IAc) no campo pelo método de anéis concêntricos, considerando o tempo de infiltração igual ao tempo de concentração da Bacia de 3 horas (Moreira, 2005) que foi considerada como Infiltração Potencial (S) e, posteriormente, aplicada à Equação (1) para o cálculo do escoamento superficial no ponto amostrado. O método do Infiltrômetro de Anéis Concêntricos (IANC) foi adotado para a determinação da infiltração da água, seguindo-se a metodologia descrita em Bernardo (1982). Os testes de infiltração de água no solo, visando determinar a infiltração acumulada (IAc) e a velocidade de infiltração básica (VIB), foram feitos em 5 pontos da Bacia com cobertura vegetal do tipo Pasto Sujo (Figura 1), os quais foram identificados pelas coordenadas geográficas obtidas por meio de receptor GPS, conforme mostra a Tabela 1. Em cada ponto, foram feitas 4 medidas da densidade do solo (ds) e da porosidade total (p) conforme o método de Bouyoucos (EMBRAPA, 1997). 
Tabela 1. Coordenadas Geográficas, em UTM, dos pontos onde foram realizados os testes de infiltração (Zona 23 - Hemisfério Sul DATUM WGS 84).

\begin{tabular}{ccc}
\hline Cobertura de Pasto Sujo & E (m) & N (m) \\
\hline Ponto 1 & 446.996 & 7.452 .890 \\
Ponto 2 & 447.015 & 7.452 .818 \\
Ponto 3 & 446.950 & 7.452 .846 \\
Ponto 4 & 446.987 & 7.452 .868 \\
Ponto 5 & 446.964 & 7.452 .885 \\
\hline
\end{tabular}

\section{$2^{\circ}$ ) Método CN para cobertura predominante (Pasto Sujo)}

Considerou-se que a cobertura vegetal da bacia era totalmente constituída de Pasto Sujo, em boa condição hidrológica (Aguiar et al., 2003) e solo pertencente ao grupo C, cujo valor de CN é igual a 75, segundo Setzer e Porto (1979), para o cálculo da infiltração potencial (S), o qual foi, posteriormente, aplicado à Eq. 1 para o cálculo do escoamento superficial. O solo estava na condição II de umidade (chuva dos últimos 5 dias antecedentes entre 15 e $40 \mathrm{~mm}$ ).

\section{$\left.3^{\circ}\right)$ Método CN Ponderado}

Consideraram-se as diversas classes de cobertura vegetal da bacia extraídas de Aguiar et al. (2003) para a definição do valor do $\mathrm{CN}_{\text {ponderado }}$ (Tabela 2) para o cálculo da infiltração potencial (S), posteriormente utilizado na Eq. 1 para o cálculo do escoamento superficial.

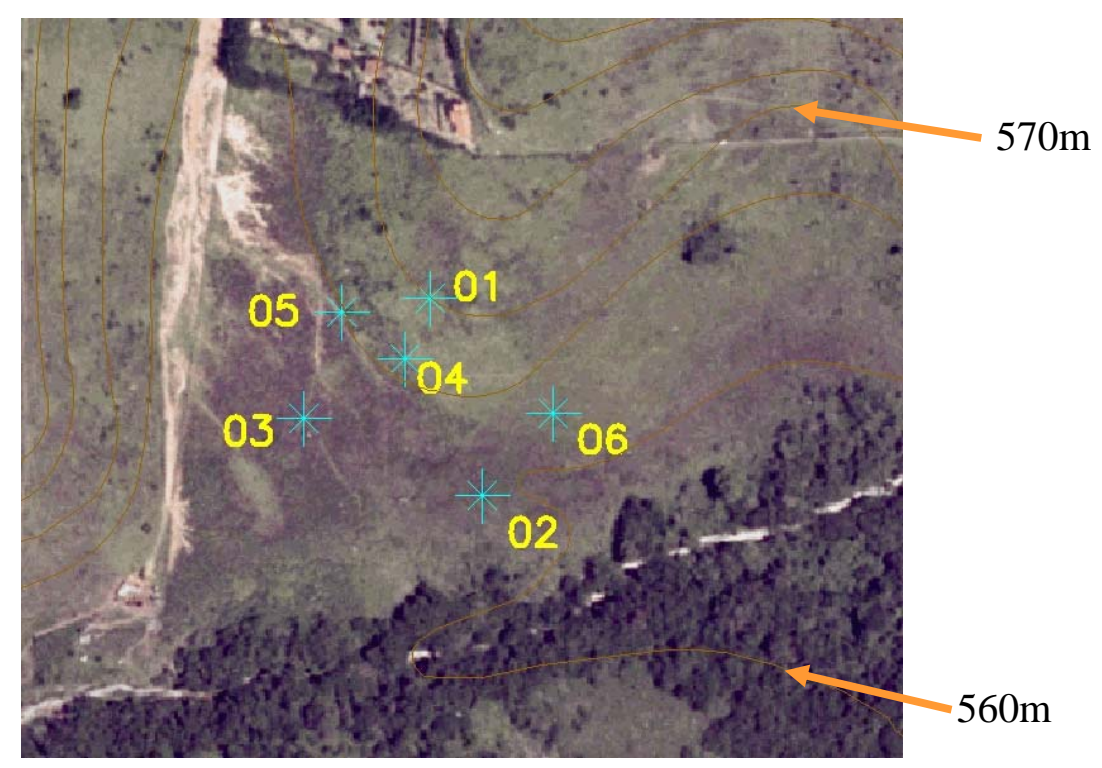

Figura 1. Pontos onde foram realizados os testes de infiltração próximo ao ribeirão Itaim. 


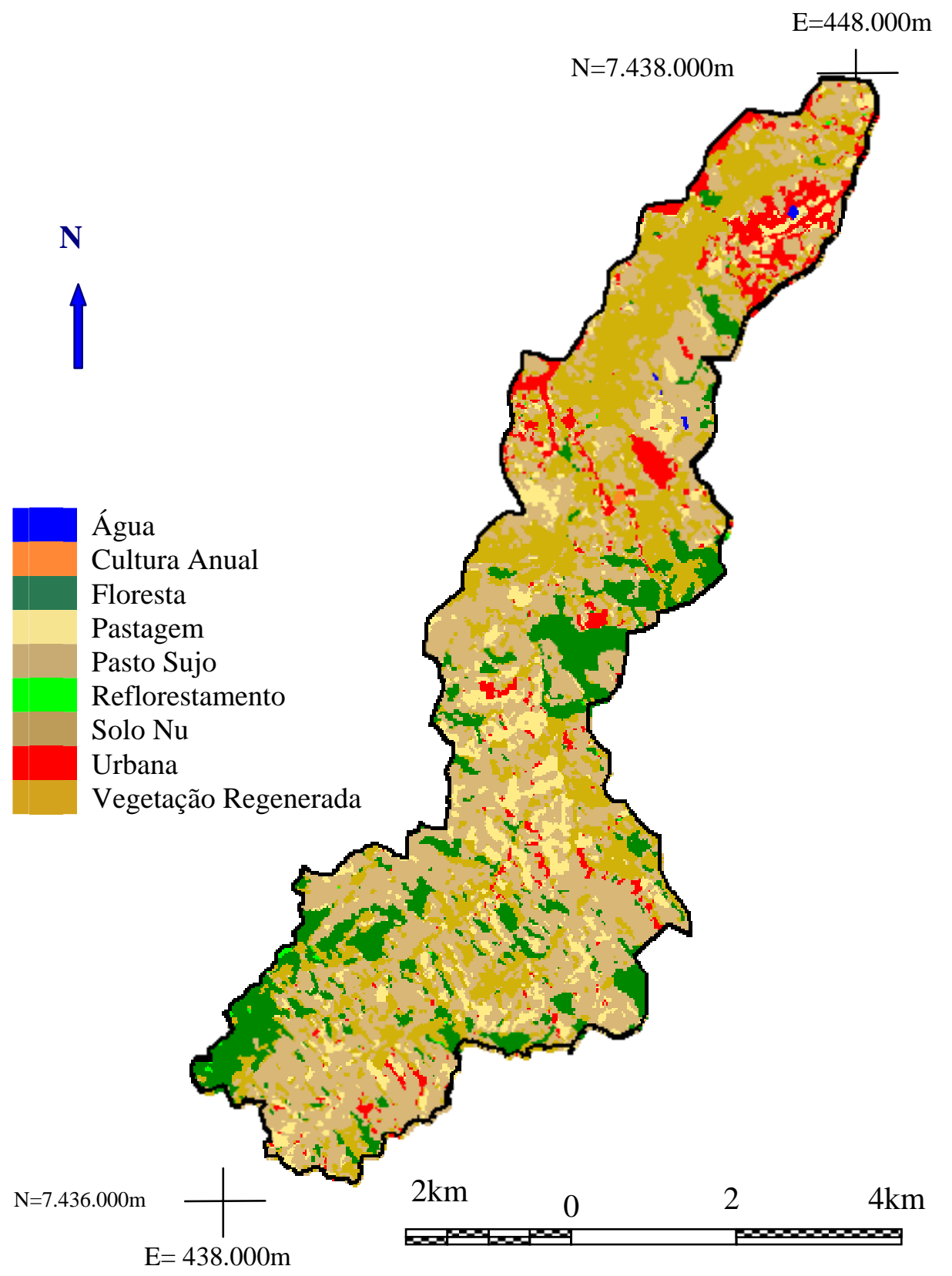

Figura 2. Classes de uso do solo na bacia hidrográfica do Ribeirão Itaim em 2003, coordenadas UTM, datum SAD 69.

Fonte: Aguiar et al. (2003).

\section{RESULTADOS E DISCUSSÃO}

A Tabela 2 apresenta a área das classes de cobertura do solo em ha e a sua porcentagem em relação a área total da bacia do Ribeirão Itaim (AGUIAR et al., 2003); resultados obtidos por meio da utilização do software SPRING no LAGEO (Laboratório de Geoprocessamento, Sensoriamento Remoto e Informática Rural do Departamento de Ciências Agrárias da Universidade de Taubaté - UNITAU). As condições hidrológicas e valores de CN para cada classe de cobertura do solo foram obtidos de Setzer e Porto (1979).

Os resultados das determinações da Velocidade de Infiltração Básica (VIB) e da Infiltração Acumulada (IAc) em áreas de pasto sujo são apresentados nas Figuras 3, 4, 5, 6 e 
7. Em geral, houve uma pequena variação nos valores de Velocidade de Infiltração, o que influenciou na duração dos testes e nos valores de Infiltração Acumulada obtidos.

Tabela 2. Classes de uso do solo, condição hidrológica adotada e os respectivos valores de CN para a bacia do Ribeirão Itaim.

\begin{tabular}{|c|c|c|c|c|c|}
\hline \multirow{2}{*}{ Classes } & \multicolumn{2}{|c|}{2003} & \multirow{2}{*}{$\begin{array}{c}\text { Condição } \\
\text { Hidrológica }\end{array}$} & \multicolumn{2}{|c|}{ CN } \\
\hline & Área (ha) & $\%$ & & Sigla & Valor \\
\hline Pasto sujo & 2.053 & 35,4 & Boa & CNps & 75 \\
\hline Pastagem & 526 & 9,1 & Ruim & $\mathrm{CNp}$ & 86 \\
\hline Floresta & 751 & 12,9 & Boa & CNf & 55 \\
\hline $\begin{array}{l}\text { Vegetação Natural em } \\
\text { Regeneração }\end{array}$ & 1.563 & 26,9 & Boa & CNvnr & 42 \\
\hline Solo $\mathrm{Nu}$ & 534 & 9,2 & Boa & CNsn & 88 \\
\hline Reflorestamento & 12 & 0,2 & Boa & $\mathrm{CNr}$ & 55 \\
\hline Urbana & 363 & 6,2 & $\begin{array}{c}65 \% \\
\text { Impermeável }\end{array}$ & $\mathrm{CNu}$ & 90 \\
\hline Cultura anual & 3 & 0,0005 & Boa & CNan & 70 \\
\hline Água & 4 & 0,1 & & & \\
\hline Área total das classes & 5.809 & 100 & & CNpond & 66,57 \\
\hline
\end{tabular}

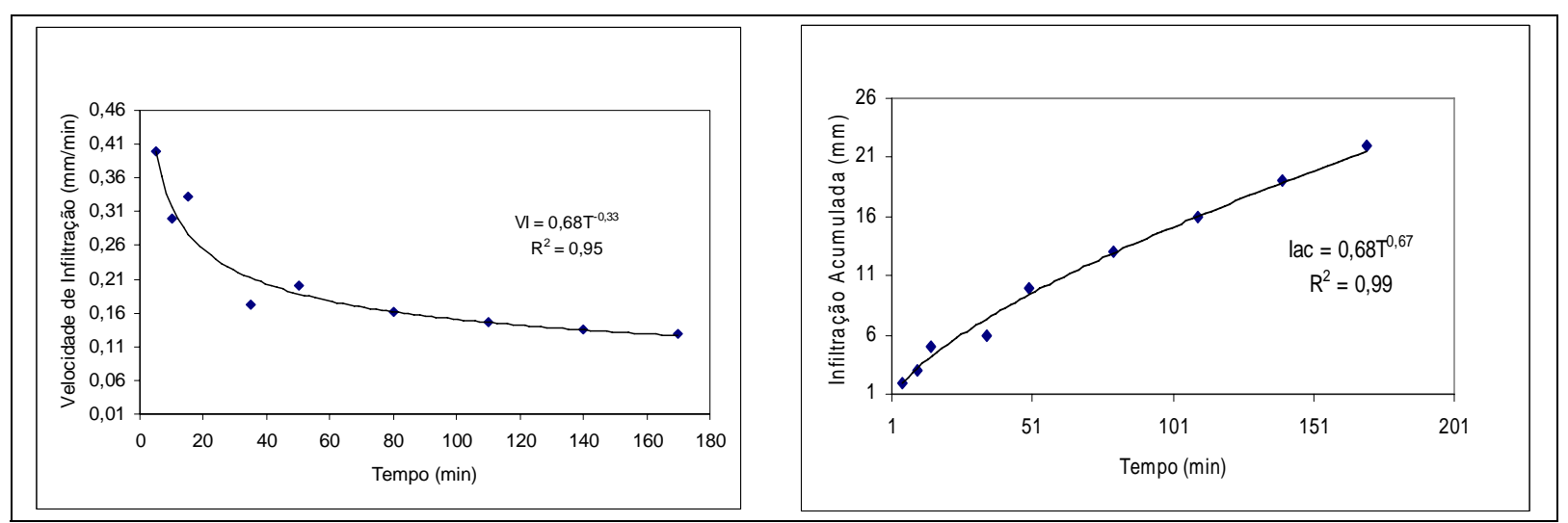

Figura 3. Velocidade de Infiltração e Infiltração Acumulada, em área com cobertura de Pasto sujo no Ponto 1.

Observa-se na Figura 3 que, por volta dos 170 minutos, a Velocidade de Infiltração tende a se estabilizar, atingindo a Velocidade de Infiltração Básica (VIB), momento em que já acumulou no solo $22 \mathrm{~mm}$ de lâmina de água.

Por outro lado, no Ponto 2, a Velocidade de Infiltração se estabilizou por volta dos 300 minutos, atingindo a Velocidade de Infiltração Básica (VIB), momento em que acumulou no solo quantidade de $22 \mathrm{~mm}$ de água (Figura 4), o que significa que o solo tornou-se saturado naquele momento.

Observa-se na Figura 5 que a Velocidade de Infiltração se estabilizou por volta dos 190 minutos, atingindo a Velocidade de Infiltração Básica (VIB) e acumulou nesse tempo uma lâmina de água de $15 \mathrm{~mm}$. 
AGUIAR, L. S. G.; TARGA, M. S.; BATISTA, G. T. Escoamento superficial na bacia hidrográfica do Ribeirão Itaim. Ambi-Agua, Taubaté, v. 2, n. 1, p. 44-56, 2007. (doi:10.4136/ambi-agua.19)
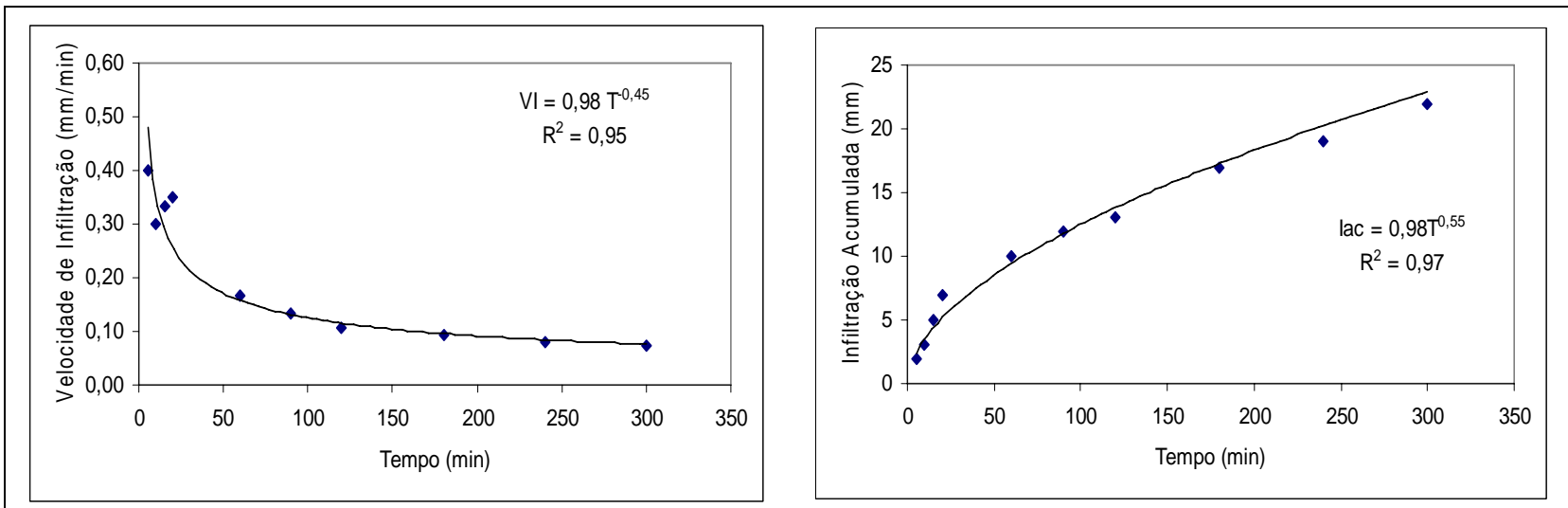

Figura 4. Velocidade de Infiltração e Infiltração Acumulada, em área com cobertura de Pasto sujo no Ponto 2.

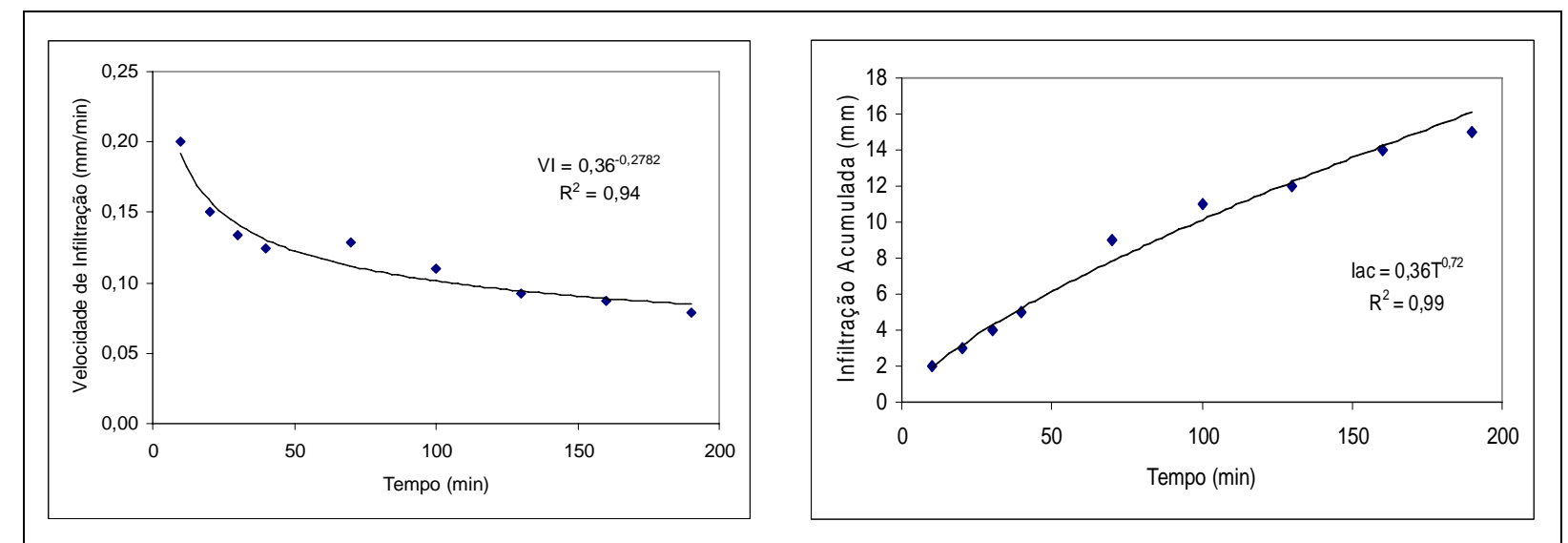

Figura 5. Velocidade de Infiltração e Infiltração Acumulada, em área com cobertura de Pasto sujo no Ponto 3.

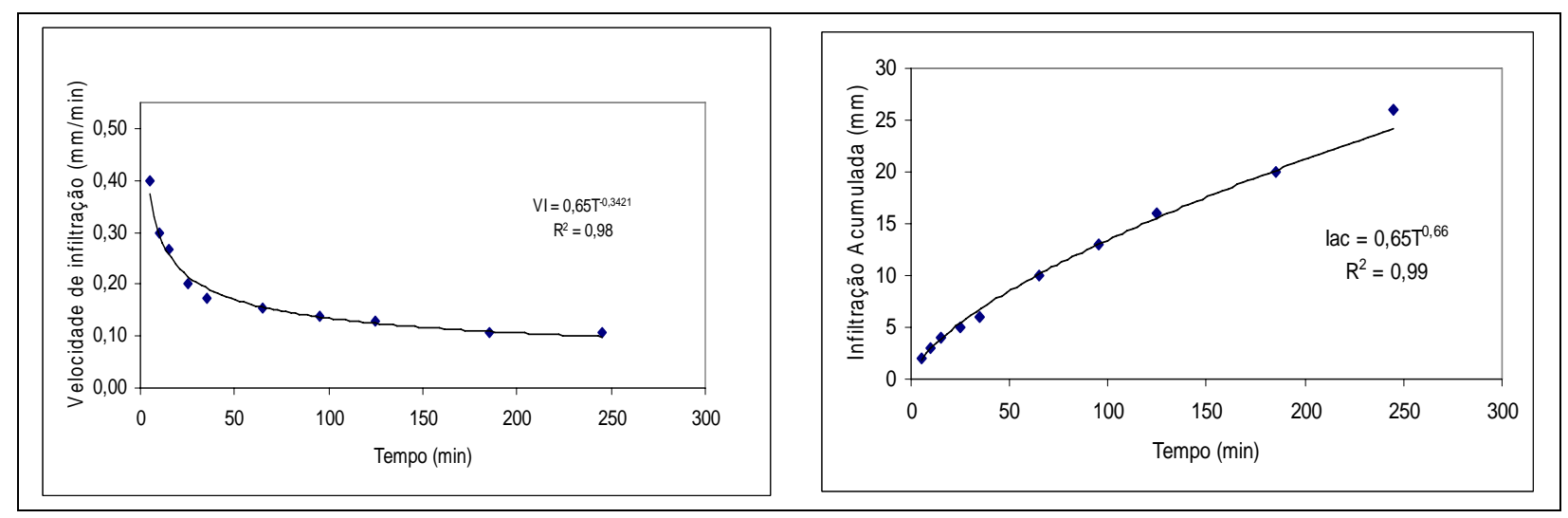

Figura 6. Velocidade de Infiltração e Infiltração Acumulada, em área com cobertura de Pasto sujo no Ponto 4.

No Ponto 4 (Figura 6), a infiltração se estabilizou aos 245 minutos, atingindo a Velocidade de Infiltração Básica (VIB), apresentando um valor de infiltração acumulada de $26 \mathrm{~mm}$.

A medida da Velocidade de Infiltração no Ponto 5 realizada na mesma classe de cobertura vegetal (pasto sujo) se estabilizou aos 240 minutos, atingindo a Velocidade de Infiltração Básica (VIB) e apresentou um valor de infiltração acumulada de 16 mm. 
Valores de densidade do solo (ds) e porosidade total (p), em duas profundidades, para cada ponto amostrado para medidas de infiltração, juntamente com os valores de Infiltração Acumulada e de Velocidade de Infiltração Básica são apresentados na Tabela 3.

Os valores de Infiltração Acumulada (IAc) e as respectivas equações obtidos dos testes de infiltração em campo encontram-se na Tabela 4.
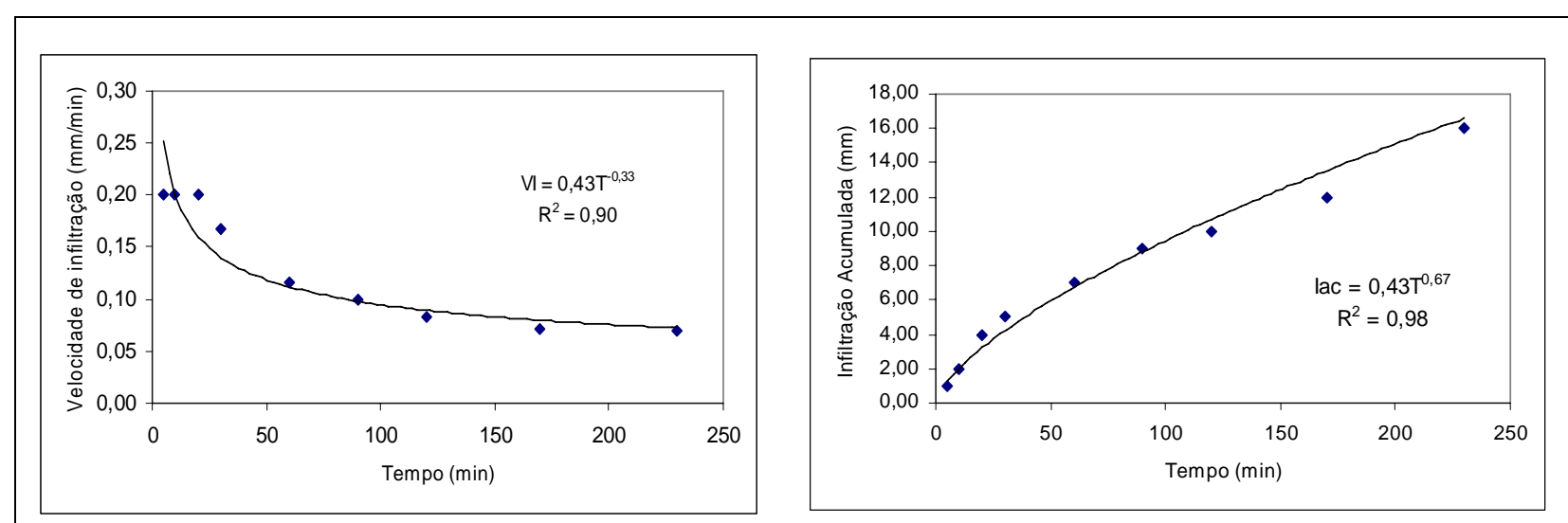

Figura 7. Velocidade de Infiltração e Infiltração Acumulada, em área com cobertura de Pasto sujo no Ponto 5.

Tabela 3. Valores de densidade do solo (ds) e porosidade total (p), Infiltração Acumulada (IAc) e Velocidade de Infiltração Básica $(\mathrm{mm} / \mathrm{h})$ para cada ponto de teste de infiltração.

\begin{tabular}{|c|c|c|c|c|c|c|}
\hline $\begin{array}{c}\text { Uso e } \\
\text { Cobertura }\end{array}$ & \multicolumn{2}{|c|}{$0-20 \mathrm{~cm}$} & \multicolumn{2}{|c|}{$20-40 \mathrm{~cm}$} & \multicolumn{2}{|c|}{$0-40 \mathrm{~cm}$} \\
\hline Pasto Sujo & $\begin{array}{c}\text { ds } \\
\left(\mathrm{g} / \mathrm{cm}^{3}\right. \\
\quad)\end{array}$ & $\begin{array}{c}\mathbf{p} \\
(\%)\end{array}$ & $\begin{array}{c}\text { ds } \\
\left(\mathrm{g} / \mathrm{cm}^{3}\right)\end{array}$ & $\begin{array}{c}\mathbf{p} \\
(\%)\end{array}$ & $\begin{array}{c}\text { IAc } \\
(\mathbf{m m})\end{array}$ & $\begin{array}{c}\text { VIB } \\
(\mathrm{mm} / \mathrm{h} \\
)\end{array}$ \\
\hline 1 & 1,47 & 47,31 & 1,50 & 48,78 & 22 & 7,8 \\
\hline 2 & 1,40 & 49,94 & 1,52 & 44,84 & 22 & 4,2 \\
\hline 3 & 1,55 & 40,21 & 1,63 & 40,15 & 15 & 4,8 \\
\hline 4 & 1,40 & 47,19 & 1,58 & 43,09 & 26 & 6,6 \\
\hline 5 & 1,42 & 49,39 & 1,56 & 45,25 & 16 & 4,2 \\
\hline Média & 1,45 & 46,81 & 1,56 & 44,42 & 20 & 5,5 \\
\hline
\end{tabular}

Fonte: Aguiar (2003).

Considerando a classificação de Reichardt (1987), os valores de Velocidade de Infiltração Básica (VIB) obtidos neste trabalho (Tabela 3) demonstram que o solo apresenta de baixa a média capacidade de infiltração. A velocidade de infiltração reflete as condições físicas do solo, tais como sua estrutura, porosidade, densidade, bem como a presença ou ausência de camadas compactadas de solo. Dessa forma, deduz-se, para o solo em questão, que os valores elevados de densidade do solo e baixa porosidade total para as profundidades de 0-20 e 20-40 (Tabela 3) estão influenciando a infiltração de água no solo, o que corrobora os resultados obtidos por Centurion et al. (2001). A baixa velocidade de infiltração promove maior escoamento de água na bacia, maior erosão e se constitui em um fator importante na taxa de sedimentação do ribeirão Itaim, que, em sua vazão média de $2.146 \mathrm{~m}^{3} / \mathrm{h}$, apresentou uma vazão sólida de 6.848 kg/dia (Moreira, 2005). 
Tabela 4. Equações de Infiltração Acumulada e valores da Infiltração Acumulada (IAc) obtidos nos testes de campo para o tempo de duração da chuva igual ao tempo de concentração.

\begin{tabular}{cccc}
\hline $\begin{array}{c}\text { Uso e } \\
\text { Cobertura } \\
\text { do Solo } \\
\text { (Pasto Sujo) }\end{array}$ & $\begin{array}{c}\text { Tempo de } \\
\text { Concentração } \\
\text { [min] }\end{array}$ & $\begin{array}{c}\text { Equação de Infiltração } \\
\text { Acumulada }\end{array}$ & $\begin{array}{c}\text { Infiltração } \\
\text { Acumulada } \\
\text { [mm] }\end{array}$ \\
\hline $\mathbf{1}$ & 180 & IAc $=0,68 \times 180^{0,67}$ & 22,32 \\
$\mathbf{2}$ & 180 & IAc $=0,98 \times 180^{0,55}$ & 17,27 \\
$\mathbf{3}$ & 180 & IAc $=0,36 \times 180^{0,72}$ & 15,47 \\
$\mathbf{4}$ & 180 & IAc $=0,65 \times 180^{0,66}$ & 19,79 \\
$\mathbf{5}$ & 180 & IAc $=0,42 \times 180^{0,67}$ & 14,06 \\
\hline
\end{tabular}

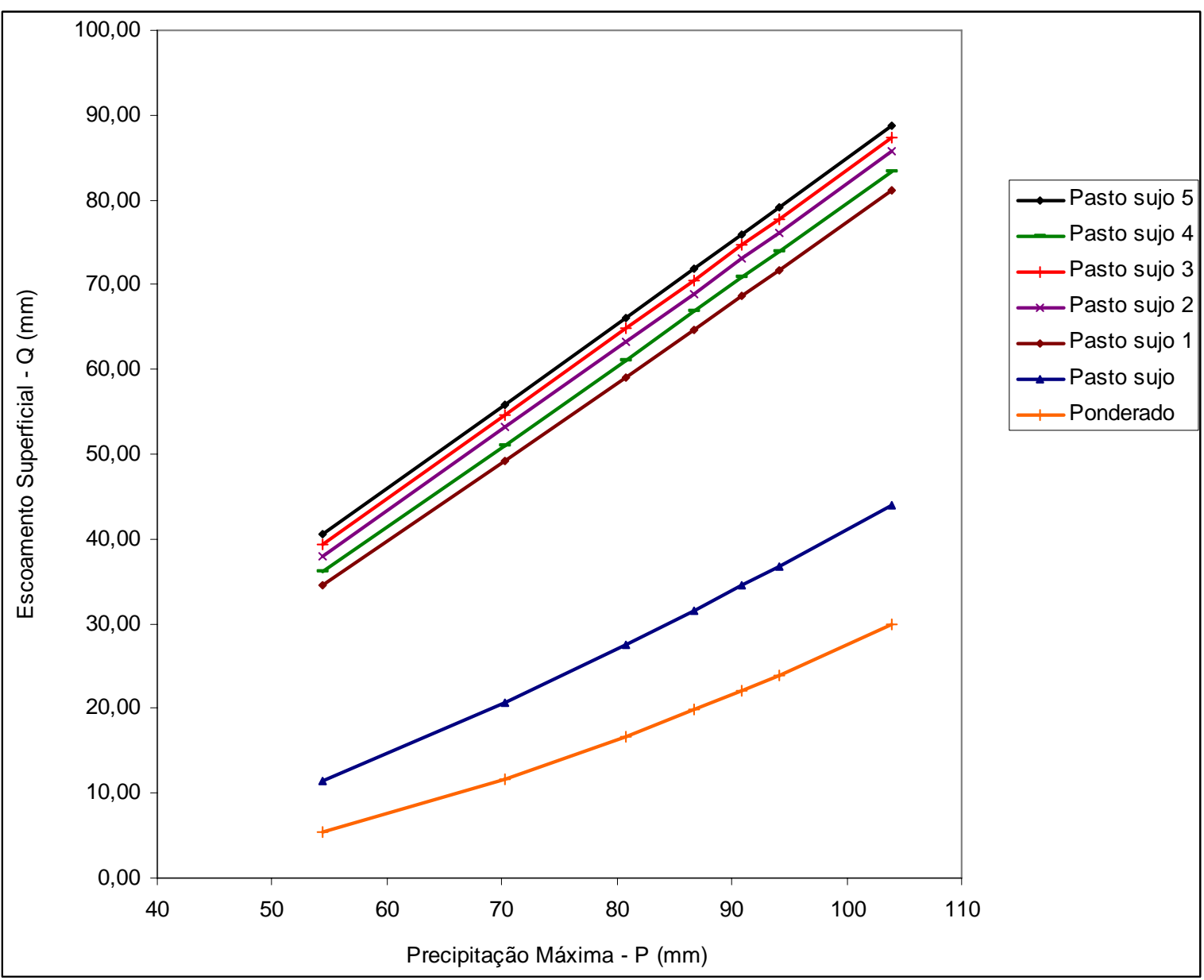

Figura 8. Variação do Escoamento Superficial em função da Precipitação Máxima na bacia do Ribeirão Itaim.

Em geral, o escoamento superficial aumentou à medida que aumentou a precipitação máxima (Figura 8). O aumento foi mais acentuado quando se utilizaram dados de infiltração potencial levantados no campo (Método 1; Figura 8, Pasto sujo). Os valores de infiltração potencial foram $\mathrm{S}=84,7 \mathrm{~mm}$ e $\mathrm{S}=127 \mathrm{~mm}$, respectivamente, quando se considerou a 
cobertura vegetal pasto sujo com $\mathrm{CN}=75$ para toda a bacia (Método 2) e quando se utilizou o valor de CN ponderado (Método 3), que levou em consideração a área de cada classe de uso e cobertura do solo (CNpond $=66,57$ ). Pelo valor de CNpond menor, observa-se que, ao se assumir um único tipo de cobertura para a bacia, superestima-se o valor de infiltração e, em conseqüência, subestima-se o escoamento.

Pode-se com isso inferir que o método Curva-Número aplicado com base em valores de CN (Setzer e Porto, 1979) subestimou o escoamento superficial na bacia do Ribeirão do Itaim e, portanto, esse método não pode ser aplicado de forma generalizada, sem que se obtenham medidas em campo de infiltração de água no solo para se promover ajustes para situações locais.

\section{CONCLUSÕES}

As metodologias adotadas para o cálculo da taxa de infiltração de água permitiram a estimativa do escoamento superficial da bacia de forma consistente para diversos valores de precipitações máximas (54,4; 70,3; 80,8; 86,7; 90,9; 94,1 e 103,9 mm) para o tempo de duração de 3 horas e para os tempos de retorno de 2, 5, 10, 15, 25, 50 e 100 anos. Entretanto, os valores das estimativas do escoamento superficial variaram substancialmente em função do método utilizado (infiltrômetro em campo vs. CN) e em função do uso e cobertura do solo (CN tradicional vs. CN ponderado).

Os valores de escoamento superficial obtidos pelo Curva-Número tanto convencional (cultura predominante) quanto ponderado (levando-se em consideração todas as classes de uso e cobertura do solo) apresentaram-se mais baixos que os estimados com base em medidas de infiltração de água no solo, obtidos em campo, com anéis concêntricos, para os diversos valores de precipitação e tempos de retorno associados.

\section{REFERENCIAS}

AGUIAR, L. S. G. Estimativa do escoamento superficial a partir de testes da infiltração potencial na Bacia do Ribeirão Itaim, Taubaté - SP. 2004. 104f. Dissertação (Mestrado em Ciências Ambientais) - Departamento de Ciências Agrárias, Universidade de Taubaté, Taubaté, 2004.

AGUIAR, L. S. G.; BATISTA, G. T.; MONTESI, E. C.; PEREIRA, W. F. Dinâmica do uso e ocupação do solo na microbacia do ribeirão Itaim utilizando dados de sensoriamento remoto e SIG. In: ENCONTRO DE INICIAÇÃO CIENTÍFICA, 8., 2003; MOSTRA DE PÓS-GRADUAÇÃO, 4., 2003, Taubaté. Resumo... Taubaté: Universidade de Taubaté, 2003. p. 255.

BERNARDO, S. Manual de irrigação. 2. ed. Viçosa: Imprensa Universitária, 1982. 463p.

BRAGA JUNIOR, B. P.; CONEJO, J. G. L. Simulação digital do ciclo hidrológico através do "Stanford Watershed Model IV". In: Hidrologia dinâmica: curso de engenharia hidrológica. São Paulo: EPUSP/DAEE/ABRH, 1983. p. B1-B23. vol. 1.

CENTURION, F. J.; CARDOSO J. P.; NATALI, W. Efeitos de formas de manejo em algumas propriedades físicas e químicas de um latossolo vermelho em diferentes agroecossistemas. Revista Brasileira de Engenharia Agrícola e Ambiental, Campina Grande, v. 5, n. 2, p. 254-258, 2001. 
DIAMOND, J.; SHANLEY, T. Infiltration rate assessment of some major soils. Irish Geography, Dublin, v. 36, n. 1, p. 32-46, 2003.

EMPRESA BRASILEIRA DE PESQUISA AGROPECUÁRIA. Serviço Nacional de Levantamento e Conservação dos Solos. Manual de métodos de análise de solo. 2.ed. Rio de Janeiro: Ministério da Agricultura, 1997. 212 p.

FISCH, G. Distribuição da Precipitação em Taubaté, Vale do Paraíba (SP). Revista Biociências, Taubaté, v. 5, n. 2, p. 7-11, 1999.

GROVE, M.; HARBOR, J.; ENGEL, B. Composite vs. distributed curve numbers: effects on estimates of storm runoff depth. Journal of the American Water Resources Association, Middleburg, v. 34, n. 5, p. 1015-1023, 1998.

JACOBS, J. H.; SRINIVASAN R. Effects of curve number modification on runoff estimation using WSR-88D rainfall data in Texas watersheds. Journal of soil and water conservation, Ankeny, v. 60, n. 5, p. 274-275, 2005.

MACHADO, R. E. Simulação de escoamento de produção de sedimentos em uma microbacia hidrográfica utilizando técnicas de modelagem e geoprocessamento. 2002. 154 f. Tese (Doutorado em Agronomia) - Escola Superior de Agricultura, Universidade de São Paulo, Piracicaba, 2002.

MAHESHAWARI, B. L. Development of an automated double ring infiltrometer. Australian Journal of Soil Research, Collingwood, v. 34, p. 709-714, 1996.

MARTINEZ JR. F.; MAGNI, N. L. G. Equações de chuvas intensas do Estado de São Paulo. In: SÃO PAULO (Estado). Secretaria de Recursos Hídricos, Saneamento e Obras. Departamento de Águas e Energia Elétrica. Centro Tecnológico de Hidráulica e Recursos Hídricos. São Paulo: Escola Politécnica da Universidade de São Paulo, 1999, 125p. Disponível em: <http://www.sigrh.sp.gov.br/sigrh/basecon/ecisp/index.htm>. Acesso em 6 maio 2005.

MOREIRA, D. W. Intensidades máximas de chuvas e sua influência na vazão máxima e sedimentação do Ribeirão Itaim, Taubaté - SP. 2005. 160f. Tese (Doutorado em Ciências Ambientais) - Universidade de Taubaté, Taubaté, 2005.

NATIONAL RESOURCES CONSERVATION SERVICE. Estimation of direct runoff from storm raifall. In: Hydrology: national engineering handbooks. Washington: USDA, 1997. 79 p. part 630. cap. 10. Disponível em: <www.ftw.nrcs.usda.gov>. Acesso em abril 2007.

REICHARDT, K. A água em sistemas agrícolas. São Paulo: Manole, 1987. 186 p.

ROCHA, J. V. El Sistema de Informaciones Geográficas (SIG) en los Contextos de Planificación del Medio Físico y de las Cuencas Hidrográficas. In: REPETTO, F.L.; KAREZ, C. S. Aspectos geológicos de protección ambiental. Montevidéu: UNESCO, 2000. p. 112-123.

SBRUZZI, R. S. Metodologia para verificação da adequação do uso da terra na bacia do Ribeirão Itaim, afluente do rio Una, Taubaté, SP. 2004. 75 f. Dissertação (Mestrado em Ciências Ambientais) - Departamento de Ciências Agrárias, Universidade de Taubaté, Taubaté, 2004. 
SECCO, D. et al. Atributos físicos e produtividade de culturas em um latossolo vermelho argiloso sob diferentes sistemas de manejo. Revista Brasileira de Ciência do Solo, Campinas, v. 29, n. 3, p. 407-414, 2005.

SETZER, J.; PORTO, R. L. L. Tentativa de avaliação do escoamento superficial de acordo com o solo e seu recobrimento vegetal, nas condições do estado de São Paulo. Boletim Técnico DAEE, São Paulo, v. 2, n. 2, p. 81-104, 1979.

SMEMOE, C. M.; NELSON, E. J.; ZHAO, B. Spatial averaging of land use and soil properties to develop the physically-based Green and Ampt parameters for HEC-1. Environmental Modelling \& Software, [S.l.], v. 19, n. 6, p. 525-535, 2004.

TRIPATHI, M. P.; PANDA, R. K.; RAGHUWANSHI, N. S. Identification and prioritization of critical sub-watersheds for soil conservation management using the Swat Model. Biosyst. Eng., London,v.85, n.3, p.365-379, 2003.

WENDLAND, W. M. Temporal responses of surface-water and ground-water to precipitation in Illinois. Journal of the American Water Resources Association, Middleburg, v. 37, n. 3, p. 685-693, 2001. 


\title{
Estimativa da recarga do aqüifero freático na bacia do Rio Una, no município de Taubaté, SP \\ (doi:10.4136/ambi-agua.20)
}

\section{Jair Santoro; Helio Nóbile Diniz; Nathália Torras Correia; Felipe Rodrigues Carbone; Luciana Campos de Oliveira Sciotta}

\author{
Instituto Geológico do Estado de São Paulo, Secretaria do Meio Ambiente \\ E-mail: igeologico@igeologico.sp.gov.br, \{jairsantor,heliodiniz1,fr_carbone\}@yahoo.com.br, \\ \{nathytorras, lu_sciotta\}@hotmail.com
}

\section{RESUMO}

Este trabalho apresenta os resultados dos estudos relacionados com a estimativa da recarga do aqǘfero freático na bacia do rio Una, Município de Taubaté. O objetivo deste estudo foi desenvolver políticas públicas a fim de viabilizar o uso sustentável dos recursos hídricos superficiais e subterrâneos no Departamento de Ciências Agrárias da UNITAU. As principais atividades realizadas foram: a determinação dos índices físicos do solo, a caracterização textural do perfil, a construção de piezômetros, o monitoramento do nível d'água do aqüífero freático, realização de balanço hídrico climatológico e análises físicoquímicas e bacteriológicas. Os ensaios de caracterização geotécnica realizados mostraram que o solo é bastante poroso, com porosidade em torno de $53 \%$ e umidade natural de aproximadamente 30\%. Quanto aos resultados das análises granulométricas verificou-se que quanto maior a profundidade mais uniforme é a distribuição da textura dos sedimentos, desde finos argilosos, até grossos arenosos. Estabeleceu-se uma relação consistente entre excedente hídrico, porosidade, grau de saturação e medidas piezométricas em uma série histórica diária no período de um ano. Os métodos utilizados e as medidas obtidas permitiram calcular a descarga de água do aqüífero freático nas fontes, sendo de $14,5 \mathrm{~mm} /$ dia no período mais chuvoso, e de 1,9 mm nos outros períodos do ano. A existência de coliformes fecais no aqüífero freático mostrou que há presença de bactérias oriundas da infiltração de águas provenientes de fossas sépticas ou, do ribeirão Itaim, contaminadas por esgoto doméstico.

Palavras-chave: recarga; aqüífero freático; solos; infiltração.

\section{Estimation of the phreatic aquifer recharge of Una watershed in Taubaté, SP}

\begin{abstract}
This paper presents results related to the estimation of the phreatic aquifer recharge of the Una watershed in Taubaté, SP. The goal of this study was to develop public policies for the sustainable use of superficial and phreatic water at the Department of Agrarian Sciences of the University of Taubaté. The main results of this study are: determination of the soil physical indices, characterization of the textural profile, construction of piezometers, monitoring of the watertable, determination of the hydric climatological balance, and physicchemical and bacteriological analyses of phreatic water. The geotechnical characterization showed that the soil have high total porosity (about 53\%), and natural moisture of about $30 \%$. Regarding the results of soil particle size measurements, it was observed that the deeper the soil the more uniform is the sediments texture distribution, varying from fine loamy, to coarse sandy. It is established a consistent relation between hydric balance and porosity, saturation
\end{abstract}


and piezometric measurement in a daily historical series during one year. Methods and results allowed to calculate the phreatic aquifer discharge of several springs, that varied from 14.5 $\mathrm{mm}$ /day in the rainy period to $1.9 \mathrm{~mm}$ /day in other periods. The existence of faecal coliforms in phreatic aquifer, in variable amounts, showed that there are bacterias in the water infiltrated from septic cesspools or from the nearby Itaim River, contaminated by domestic sewage.

Keywords: recharge; phreatic aquifer; soils; infiltration.

\section{INTRODUÇÃO}

Este trabalho apresenta os resultados dos estudos desenvolvidos em uma área localizada na bacia hidrográfica do rio Una, afluente da margem direita do rio Paraíba do Sul, no Município de Taubaté. O objetivo deste estudo foi desenvolver políticas públicas a fim de viabilizar o uso sustentável dos recursos hídricos superficiais e subterrâneos. Ao longo dos trabalhos pôde-se destacar como principais atividades realizadas, a determinação dos índices físicos do solo; a caracterização textural do perfil do solo; a construção de piezômetros; o monitoramento do nível d'água do aqüífero freático visando estabelecer uma série histórica de medidas piezométricas; realização de balanço hídrico climatológico com os dados hidroclimáticos cadastrados no Posto Meteorológico da UNITAU/INMET, para fins de comparação entre a disponibilidade de água e a água contida no perfil do solo; o lançamento das águas pluviais escoadas nos pátios e arruamentos em bacias de infiltração; a coleta e análise físico-química e bacteriológica das águas contidas no aqüífero freático.

A área do trabalho situa-se no bairro Itaim, no Departamento de Ciências Agrárias da Universidade de Taubaté, no Município de Taubaté.

O Município de Taubaté está situado em uma área com elevada quantidade de precipitação hídrica, de modo que, em quase todos os meses do ano, excetuando o mês de agosto, há excedente hídrico. No Município, a média multianual de excedente hídrico, já descontando a água dos processos de evapotranspiração, situa-se em torno de $410,4 \mathrm{~mm}$ (média obtida no período 1993-2002).

Devido às características físicas dos solos sobrepostos aos sedimentos terciários do Grupo Taubaté, geralmente formados por latossolos vermelho-amarelos, profundos, muito porosos e permeáveis, existe uma tendência à percolação profunda das águas infiltradas provenientes do excedente hídrico. $\mathrm{O}$ escoamento superficial fica restrito às áreas impermeabilizadas pela ação antrópica, ou naquelas onde ocorrem solos hidromórficos, constituídos por argilas orgânicas, como em alguns locais da várzea do rio Paraíba do Sul. Assim, em Taubaté, os aqüíferos recebem grande quantidade de recarga todos os anos.

\subsection{Contexto geológico regional}

A bacia hidrográfica do rio Una está inserida, em parte sobre terrenos Pré-Cambrianos do Complexo Embu e, em parte, sobre depósitos da Bacia Sedimentar de Taubaté.

A Bacia Sedimentar de Taubaté faz parte de um conjunto de bacias tafrogênicas continentais, "o sistema de rifts da Serra do Mar", de Almeida (1976) e, mais recentemente, de "Rift Continental do Sudeste do Brasil", de Riccomini (1989). Sua origem é relacionada com a reativação de falhas transcorrentes E-NE do assoalho Pré-Cambriano, durante o processo de abertura do Atlântico Sul, ao longo das quais ocorreram deslizamentos gravitacionais e basculamento de blocos (Coltrinari, 1992). Os compartimentos apresentam-se como grabens assimétricos, com basculamento ora para SE, ora para NW. 
As espessuras admitidas para a Bacia de Taubaté (Hasui et al., 1978; Melo et al., 1986) variam até $850 \mathrm{~m}$, sendo essa a profundidade máxima estimada para a porção próxima à Serra da Mantiqueira, na sub-bacia de Roseira.

Hasui e Ponçano (1978) elaboraram uma coluna estratigráfica para essa bacia, reunindo no Grupo Taubaté, a Formação Tremembé e a Formação Caçapava, sendo essa designação também proposta por Carneiro et al. (1976) para os depósitos de canais e planícies de rios anastomosados na região de São José dos Campos e Caçapava.

Franco Filho e Souza (1994), ao analisarem a explotação de água em São José dos Campos, reconhecem na Bacia Sedimentar de Taubaté duas unidades, a Formação Tremembé, na base, constituída por folhelhos com níveis pirobetuminosos e argilitos de cores verde acinzentadas, com intercalações centimétricas a decimétricas de arenitos, siltitos e brechas intraformacionais, originadas em ambiente lacustre. Na parte superior, descrevem a Formação Caçapava, que é constituída por sedimentos arenosos e siltosos, com intercalações pelíticas, nas cores cinza, amarelo e vermelho, originadas em ambiente fluvial.

\subsection{Pedologia}

Os solos do Município de Taubaté, seguindo as normas vigentes no Sistema Brasileiro de Classificação de Solo (Oliveira et al., 1999), são classificados, considerando os três principais domínios estratigráficos que ocorrem na região: as rochas cristalinas (Complexo Embu), sedimentos terciários e sedimentos quaternários (Grupo Taubaté).

Nas áreas de ocorrência dos sedimentos quaternários, ao longo do rio Paraíba do Sul, os solos são classificados como Gleissolos Melânicos, com textura argilosa, e Neossolos Flúvicos, com textura média, intercalados por solos orgânicos, sendo todos em relevo plano, de várzea. Segundo Verdade e Hungria (1966), os solos hidromórficos orgânicos, no vale do rio Paraíba do Sul, são encontrados na planície aluvial do rio e nas depressões junto aos córregos ou na parte inicial de pequenos cursos d'água.

A bacia hidrográfica do rio Una situa-se na região sul-sudeste do Município de Taubaté. $\mathrm{Na}$ região, nas áreas de ocorrência do Complexo Embu, o solo é classificado como argissolo eutrófico, com textura média argilosa, em relevo forte ondulado e montanhoso (início da Serra do Mar).

Nas áreas de ocorrência de sedimentos terciários do Grupo Taubaté, ocorrem os latossolos vermelho-amarelos, parte com variação Una, intercalados por argissolos vermelhoamarelos, latossólicos, ambos com textura argilosa, em relevo suave ondulado e plano (Oliveira et al., 1999).

\subsection{Hidrogeologia regional}

No vale do rio Paraíba do Sul há dois sistemas aqüíferos principais: o das coberturas sedimentares cenozóicas (Formações Caçapava e Tremembé, e sedimentos quartenários), e o das rochas cristalinas. Os terrenos sedimentares cenozóicos formam o principal e melhor aqüífero da região. Suas características não são uniformes e variam segundo a litologia das formações sedimentares.

As rochas cristalinas ígneas e metamórficas Pré-Cambrianas não formam um aqüífero regional contínuo, mas apresentam localmente condições aqüíferas pelas falhas, fraturas e outras descontinuidades que permitem a circulação das águas subterrâneas que possibilitam a exploração por poços tubulares profundos.

O sentido dos fluxos subterrâneos é predominantemente efluente, isto é, do aqüífero freático para os rios e córregos. Segundo DAEE (São Paulo, 1977a, 1977b), a maior parte da região está sob condições freáticas e pouco confinadas, enquanto algumas áreas limitadas ficam sob pressão, formando raros aqüíferos confinados. 


\section{MATERIAIS E MÉTODOS}

Esta pesquisa constou da coleta de amostras para determinação de parâmetros físicos do solo (massa específica dos grãos, massa específica natural e umidade natural), em algumas áreas do Departamento de Ciências Agrárias da UNITAU e Fazenda Piloto da Faculdade de Agronomia, em profundidades de 0,2 e $0,4 \mathrm{~m}$ e, em taludes situados junto à estrada que limita a parte sul do Departamento, nas posições topo, meio e base, em profundidades variáveis entre 0,3 e $6 \mathrm{~m}$; realização de ensaios granulométricos e caracterização físico-química e bacteriológica das águas do aqüífero freático; construção de seis piezômetros e de pequenas barragens para favorecer a infiltração de água das chuvas nos solos das encostas.

Os resultados dos ensaios de massa específica dos grãos, massa específica natural e umidade natural foram utilizados, por meio de fórmulas de correlação, para determinação do índice de vazios, porosidade, grau de saturação e grau de aeração. Os ensaios granulométricos tiveram a finalidade de determinar a textura dos solos que auxiliaram na determinação do perfil geológico.

Os piezômetros, perfurados com trado de 4", tiveram a finalidade de obtenção de amostras para análises granulométricas e, após a instalação ter sido concluída, foram revestidos com tubos geomecânicos lisos e de filtros, e completados com pré-filtro, para serem utilizados em medidas históricas do nível d'água do aqüífero freático assim como, para coleta de amostras de água destinadas à caracterização físico-química e bacteriológica das águas subterrâneas do aqüífero freático. Nos piezômetros também foram realizados ensaios de bombeamento para determinação da condutividade hidráulica do aqüífero freático, sendo que a cota do nível d'água, na data de $16 / 03 / 2007$, no piezômetro de $\mathrm{n}^{\circ} 5$, era de 8,85 metros abaixo do nível do terreno.

As etapas da construção dos piezômetros foram as seguintes:

a) execução de furo a trado manual de 4", até $1 \mathrm{~m}$ abaixo do nível d'água atual;

b) instalação de $1 \mathrm{~m}$ de tubo de filtro (PVC azul, geomecânico, diâmetro de 2 1/2", com ranhura de 0,75 mm), tipo bolsa e luva, na parte inferior, e tubos lisos (PVC azul, geomecânico, nervurado, diâmetro de $2 \frac{1}{2}$ "), tipo bolsa e luva, na seção superior, até $0,4 \mathrm{~m}$ acima do nível do terreno;

c) instalação de tampa de PVC para isolamento superior e cap para isolamento inferior;

d) colocação de pré-filtro tipo pérola com granulometria entre 1 e $3 \mathrm{~mm}$ entre a perfuração de 4 " e os tubos lisos e tubo de filtro de $2 \frac{1 / 2}{2}$;

e) construção de proteção lateral $(0,6 \mathrm{~m} \mathrm{x} 1 \mathrm{~m})$ de alvenaria para isolamento de águas escoadas superficialmente e colocação de cascalho no interior para impedir crescimento de vegetação.

Na Figura 1 é mostrado o esquema construtivo dos piezômetros.

\subsection{Mapa de localização da área}

O Município de Taubaté está localizado no Vale do Paraíba, região sudeste do Estado de São Paulo (Figura 2). Apresenta uma extensão territorial de $655 \mathrm{~km}^{2}$. Possui clima tropical com inverno seco cuja temperatura média anual é de $21^{\circ} \mathrm{C}$ e índice pluviométrico médio anual de $1400 \mathrm{~mm}$. A principal bacia hidrográfica que caracteriza o município é a de um importante afluente da margem direita do rio Paraíba do Sul, a do rio Una. 


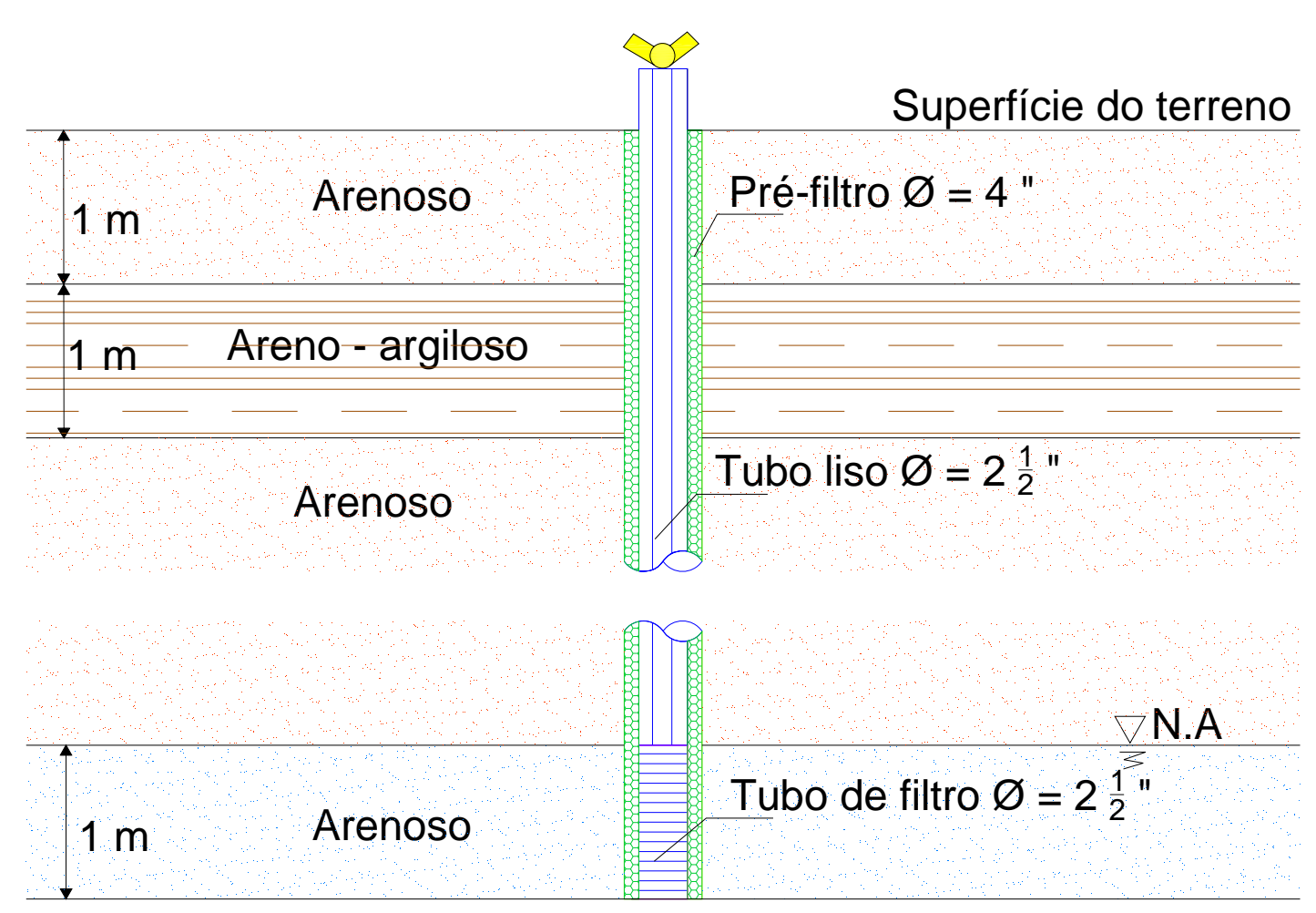

Figura 1. Esquema construtivo dos piezômetros.

\subsection{Ensaios de caracterização geotécnica dos solos}

Dentre os ensaios de caracterização do solo, foram realizados os seguintes: análises granulométricas; determinações dos índices físicos; massa específica dos grãos; umidade natural e massa específica natural (úmida e seca).

Segundo Bueno e Vilar (1984), os Índices Físicos são relações de massas e volumes entre as fases ar, água e sólidos, que servem para caracterizar as condições físicas naturais em que o solo se encontra. Tem por finalidade caracterizar o solo, com parâmetros representativos do estado em que o mesmo se encontra durante a amostragem (Stancati et al., 1981).

Para determinar os Índices Físicos foram coletadas amostras de solos. No laboratório foram determinados diretamente três índices, como segue: umidade natural (\%),segundo a NBR-6457, massa específica dos grãos $\left(\mathrm{g} / \mathrm{cm}^{3}\right)$, segundo a NBR-6508, e massa específica natural $\left(\mathrm{g} / \mathrm{cm}^{3}\right)$, úmida e seca. Os demais parâmetros foram determinados por meio de fórmulas de correlação (Nogueira, 1995). Esses parâmetros são: índice de vazios (e), a porosidade $(n)$, o grau de saturação $\left(S_{\mathrm{r}}\right)$ e o grau de aeração $\left(A_{\mathrm{r}}\right)$. As análises granulométricas foram feitas em ensaios à parte, e, segundo Santoro (1991), completam o conhecimento dos Índices Físicos do solo.

As fórmulas de correlação utilizadas foram as seguintes:

- Índice de Vazios:

$$
e=\frac{\gamma_{s}(1+w)-\gamma}{\gamma}
$$

em que:

$\gamma_{\mathrm{s}}=$ massa específica dos sólidos; $\mathrm{w}=$ teor de umidade; $\gamma=$ massa específica natural (seca)

- Porosidade:

$$
n=\frac{e}{1+e}
$$


em que:

$e=$ índice de vazios

- Grau de Saturação:

$$
S r=\frac{\gamma_{s} \cdot w}{e \cdot \gamma_{w}}
$$

em que:

$\gamma_{\mathrm{w}}=$ massa específica da água $\left(1 \mathrm{~g} / \mathrm{cm}^{3}\right)$.

- Grau de aeração:

$$
A=1-S r
$$

em que:

$S_{\mathrm{r}}=$ grau de saturação

A síntese dos resultados dos ensaios geotécnicos realizados nas amostras de solo encontra-se nas Tabelas 5 e 6.

\subsection{Análises granulométricas}

Os ensaios granulométricos têm por finalidade a obtenção das curvas de distribuição granulométrica do material amostrado (curva de porcentagens acumuladas). Estas, por sua vez (Bueno e Vilar, 1984), encontram aplicação prática na caracterização textural do material, na estimativa do coeficiente de permeabilidade e no dimensionamento de filtros de proteção de poços tubulares profundos.

Foram construídos 6 piezômetros na área do Departamento de Ciências Agrárias da Universidade de Taubaté, em grupos de dois (distantes entre si de 0,6 a 0,7 m), localizados no mapa da Figura 2. As coordenadas e cotas desses piezômetros são mostradas na Tabela 1.

Uma perfuração realizada próximo dos piezômetros 5 e 6 mostrou que o solo atinge profundidade de 16,0 m, no local. Considerando que, na época da perfuração desses piezômetros, em abril de 2006, o nível d'água estava a $8,4 \mathrm{~m}$, a espessura do aqüífero freático (sobreposto aos sedimentos terciários da Formação Tremembé, do Grupo Taubaté) era de 7,6 m.

Tabela 1. Localização dos piezômetros do Departamento de Ciências Agrárias da UNITAU.

\begin{tabular}{ccccc}
\hline Piezômetro no $^{\mathbf{0}}$ & Coord.UTM m EW & Coord.UTM m NS & Cota (m) & Profund. (m) \\
\hline 1 & 447734 & 7453020 & 564 & 4,0 \\
2 & 447738 & 7453024 & 564 & 6,0 \\
3 & 447734 & 7453020 & 564 & 5,4 \\
4 & 447738 & 7453024 & 564 & 4,5 \\
5 & 447810 & 7453042 & 568 & 9,4 \\
6 & 447810 & 7453042 & 568 & 9,4 \\
\hline
\end{tabular}

Quando da perfuração desses piezômetros, foram coletadas amostras de metro em metro e enviadas para laboratório para caracterização granulométrica dos solos. Em alguns locais amostrados para caracterização geológico/geotécnica dos solos, também foram coletadas amostras para ensaios granulométricos. 
SANTORO, J.; DINIZ, H. N.; CORREIA, N. T.; CARBONE, F. R.; SCIOTTA L. C. O. Estimativa da recarga do aqüifero freático na bacia do Rio Una, no município de Taubaté, SP. Ambi-Agua, Taubaté, v. 2, n. 1, p. 57-82, 2007. (doi:10.4136/ambi-agua.20)

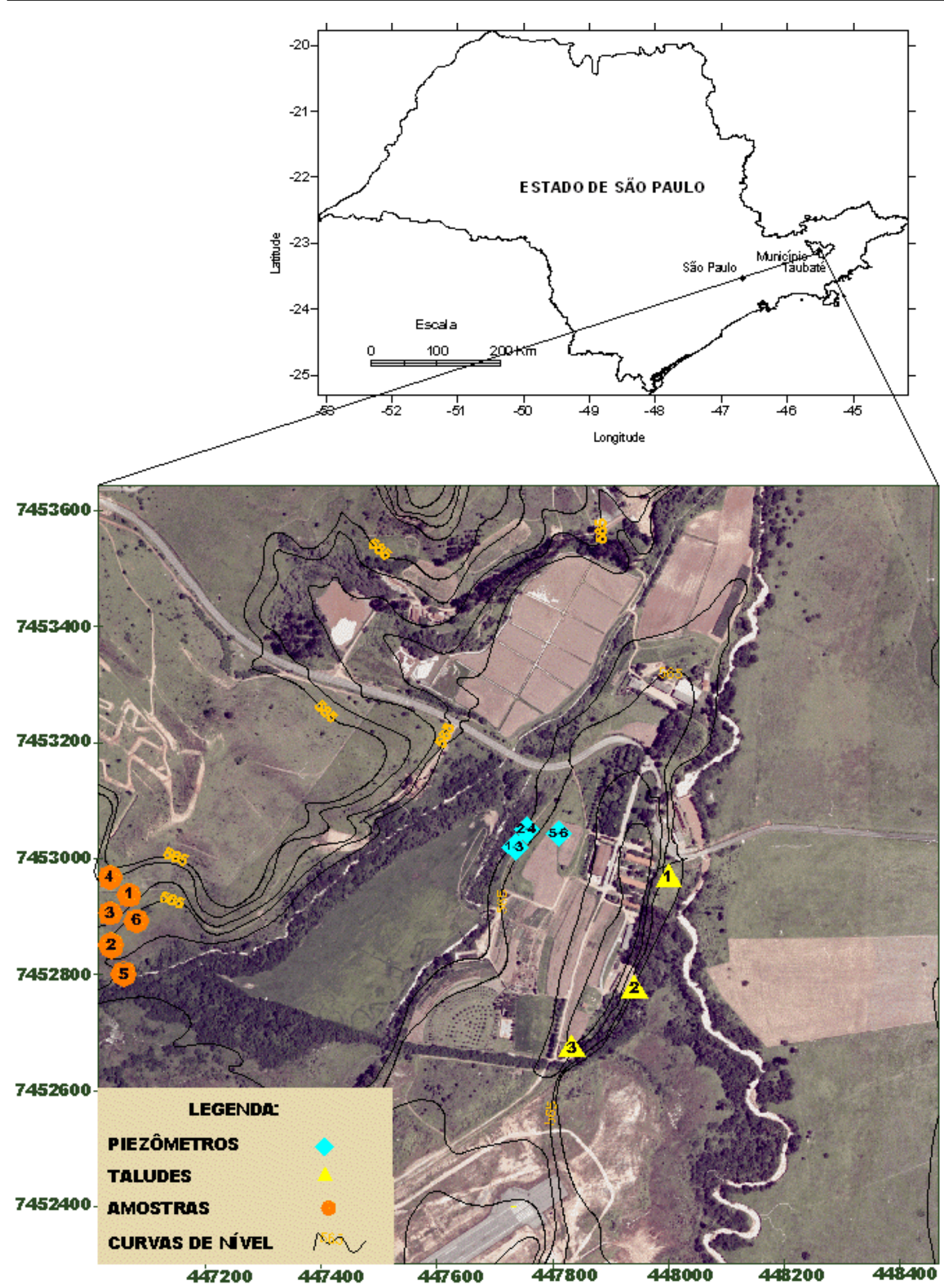

Figura 2. Mapa de localização do Município de Taubaté no Estado de São Paulo, das amostradas coletadas, piezômetros instalados e taludes amostrados.

No laboratório, as análises granulométricas foram executadas, utilizando-se o método do peneiramento para separação das frações areia e pedregulho, e da sedimentação (ou do densímetro) para a quantificação das frações silte-argilosas. 
SANTORO, J.; DINIZ, H. N.; CORREIA, N. T.; CARBONE, F. R.; SCIOTTA L. C. O. Estimativa da recarga do aqüifero freático na bacia do Rio Una, no município de Taubaté, SP. Ambi-Agua, Taubaté, v. 2, n. 1, p. 57-82, 2007. (doi:10.4136/ambi-agua.20)

$\mathrm{Na}$ Tabela 2, são mostrados os resultados encontrados para as análises granulométricas realizadas em amostras de solo obtidas durante a perfuração dos piezômetros e, nas Figuras 7 e 8 são apresentadas curvas granulométricas de duas amostras coletadas no piezômetro 1 .

Tabela 2. Resultados dos ensaios granulométricos das amostras de solos obtidas durante a perfuração dos piezômetros.

\begin{tabular}{cccccc}
\hline Piezôm. & Profund. (m) & Areias (\%) & Silte (\%) & Argila (\%) & Tipo de solo \\
\hline 1 & 1 & 49,20 & 17,66 & 33,13 & Franco argiloso arenoso \\
1 & 2 & 31,57 & 33,72 & 34,71 & Franco argiloso \\
1 & 3 & 71,45 & 13,81 & 14,74 & Franco arenoso \\
1 & 4 & 78,93 & 15,14 & 5,93 & Areia franca \\
1 & 4,3 & 69,06 & 19,06 & 11,88 & Franco arenoso \\
2 & 1 & 72,44 & 6,94 & 20,62 & Franco argiloso arenoso \\
2 & 2 & 36,71 & 31,93 & 31,39 & Franco argiloso \\
2 & 3 & 77,25 & 18,95 & 3,8 & Areia franca \\
2 & 4 & 77,06 & 15,39 & 7,55 & Areia franca \\
2 & 5 & 79,61 & 15,68 & 4,71 & Areia franca \\
2 & 6 & 79,28 & 14,90 & 5,82 & Areia franca \\
3 & 2 & 37,24 & 31,60 & 31,16 & Franco argiloso \\
3 & 4 & 76,89 & 15,06 & 8,05 & Areia franca \\
4 & 3 & 76,49 & 18,45 & 5,06 & Areia franca \\
4 & 4,5 & 73,68 & 17,83 & 8,49 & Franco arenoso \\
\hline
\end{tabular}

\subsection{Ciclo hidrológico}

O ciclo hidrológico pode ser quantificado a partir da equação hidrológica, que se baseia na lei de conservação das massas. É expressa por: entradas d'água $=$ saídas $+/$ - mudanças no armazenamento.

Rushton e Ward (1979) adotam a seguinte expressão para o balanço hídrico: $P=E+R+$ $\Delta A$ (1), em que; $P=$ precipitação, $E=$ evapotranspiração, $R=$ escoamento superficial e $\Delta A=$ mudanças no armazenamento.

O balanço hídrico é a aplicação do princípio da conservação das massas (equação da continuidade) a certa região cujo volume é conhecido e definido por determinadas condições de contorno. Durante o período em que o balanço é realizado, a diferença entre o total das entradas e o total das saídas deve ser igual às mudanças de água no armazenamento. As medidas podem ser efetuadas em massa ou em volume, desde que a densidade da água seja considerada constante.

No Departamento de Ciências Agrárias da Universidade de Taubaté, pode-se estabelecer um balanço hídrico reescrevendo-se a equação (1) sob a forma: $R+\Delta A=P-E$, e admitindose que a condição $P-E$ represente o excedente hídrico (quando positiva) ou a deficiência hídrica (quando negativa). Assim, pode-se comparar a expressão $R+\Delta A$ com o excedente ou déficit hídrico calculado pelo método de D’Angiollela e Vasconcelos (2002).

A diferença de armazenamento de água no solo $\Delta A$, em certo período, pode ser conhecida pela Porosidade $(n)$ e Grau de Saturação $\left(S_{\mathrm{r}}\right)$ encontrados no solo, e definindo-se a Capacidade de Armazenamento $\left(C_{\mathrm{A}}\right)$ como sendo igual à diferença entre a porosidade $(n)$ e a porosidade $(n) \times$ quantidade de poros preenchidos com água $\left(S_{\mathrm{r}}\right)$, ou seja: $C_{\mathrm{A}}=n-n \times S_{\mathrm{r}}$

Assim sendo, a Capacidade de Armazenamento é igual à porosidade (dada em porcentagem) menos o porcentual de poros já preenchidos com água (saturação).

A Capacidade de Armazenamento $\left(C_{\mathrm{A}}\right)$ pode ser conhecida pela porosidade e grau de saturação que são parâmetros encontrados por fórmulas de correlação, por meio dos índices físicos do solo. 
Para um armazenamento unitário $\left(A_{\mathrm{U}}\right)$, considerando um volume de solo com $1 \mathrm{~m}$ de altura, $1 \mathrm{~m}$ de largura e $1 \mathrm{~m}$ de extensão, temos: $A_{\mathrm{U}}=1 \mathrm{~m}^{3} \times C_{\mathrm{A}}$

Definindo-se a infiltração d'água no solo em um período chuvoso, como sendo $I=A_{\mathrm{U}} \times$ $\left(h_{2}-h_{1}\right)$, em que $h_{2}$ é o nível d'água do solo após um período de tempo quando o nível d'água medido inicialmente era $h_{1}$, temos que: $\Delta A=A_{\mathrm{U}} \times\left(h_{2}-h_{1}\right)$, ou seja, $R+I=P-E$, sendo $I$ igual à altura da coluna d'água infiltrada no período considerado e $R$ igual à lâmina d'água escoada.

Ainda, $I+R=$ infiltração + escoamento superficial = excedente hídrico (2).

Assim, conhecendo-se o excedente hídrico em um período chuvoso e medindo-se as diferenças de nível d'água do aqüífero freático em piezômetros, pode-se comparar com a expressão $A_{\mathrm{U}} \times\left(h_{1}-h_{2}\right)=I$, que possibilitará o conhecimento do total infiltrado e do total escoado superficialmente.

Caso o valor encontrado para $A_{\mathrm{U}} \times\left(h_{1}-h_{2}\right)$ seja igual ao excedente hídrico, conclui-se que toda a água disponível na superfície infiltrou, ou seja, o excedente hídrico é igual à infiltração.

Caso seja inferior ao excedente hídrico haverá uma parte dessa água que escoa superficialmente e não infiltra, e que, mesmo assim, ainda pode ser determinada pela expressão (2) descrita acima.

\subsection{Caracterização hidroclimática}

A bacia hidrográfica representa um sistema fechado nas condições climáticas do sudeste brasileiro. A entrada de água advém das precipitações, as saídas d'água do sistema são devidas à evapotranspiração e descarga nas fontes que abastecem o fluxo de base do rio principal. Como o aqüífero freático está saturado e em equilíbrio com as águas superficiais, já que normalmente há excedente hídrico, não devem ocorrer mudanças de armazenamento para uma série histórica de medidas multianual, podendo ocorrer pequenas mudanças somente durante o ano hidrológico, em relação aos períodos de máxima e mínima pluviosidades. Nesses períodos, as mudanças de armazenamento da água do aqüífero freático são devidas ao acréscimo de água proveniente do fluxo vertical que percola o perfil do solo ou, ao decréscimo devido às descargas nas fontes.

Para o cálculo da disponibilidade de água nas camadas superficiais do solo e sua migração para o aqüífero freático, utiliza-se do balanço hídrico. $\mathrm{O}$ balanço hídrico climatológico, em Taubaté, foi calculado pelo método proposto por D'Angiolella e Vasconcelos (2002). Nesse método são utilizadas informações meteorológicas tais como: temperatura média, umidade relativa do ar, velocidade do vento, precipitação e insolação. Esses parâmetros dão-nos o cálculo da evapotranspiração potencial e real. Com adição da capacidade de campo, esse modelo também calcula o excedente (água disponível que vai percolar para o aqüífero freático) ou a deficiência hídrica (água necessária para ser adicionada ao solo para evitar o murchamento das plantas).

Os dados hidroclimatológicos utilizados foram obtidos no Posto Meteorológico da Estação UNITAU/INMET n ${ }^{\circ}$ 83784, do Departamento de Ciências Agrárias da UNITAU, situado na Latitude $23^{\circ} 02^{\prime} \mathrm{S}$ e,Longitude $45^{\circ} 31^{\prime} \mathrm{W}$, e na altitude de 577 metros.

Os resultados do balanço hídrico multianual, utilizando dados históricos do Posto Meteorológico da Estação UNITAU/INMET n ${ }^{\circ}$ 83784, obtidos no período entre 1992 a 2003 (Figura 3) mostram que há um grande excedente hídrico (com média de 410,4 mm/ano) que ocorre nos meses de novembro a março. A deficiência hídrica ocorre nos meses de abril, junho e julho (com média de 17,7 mm/ano).

A diferença entre o excedente e a deficiência hídrica resulta no total da água disponível no solo para a infiltração e percolação profunda, ou seja, caso não haja condições geológicas 
favoráveis, ou de cobertura, para a total infiltração dessa água, ela irá escoar superficialmente. Esta subtração (excedente menos deficiência) para Taubaté, no período 1993-2002, é de 392,7 $\mathrm{mm} / \mathrm{ano}$.

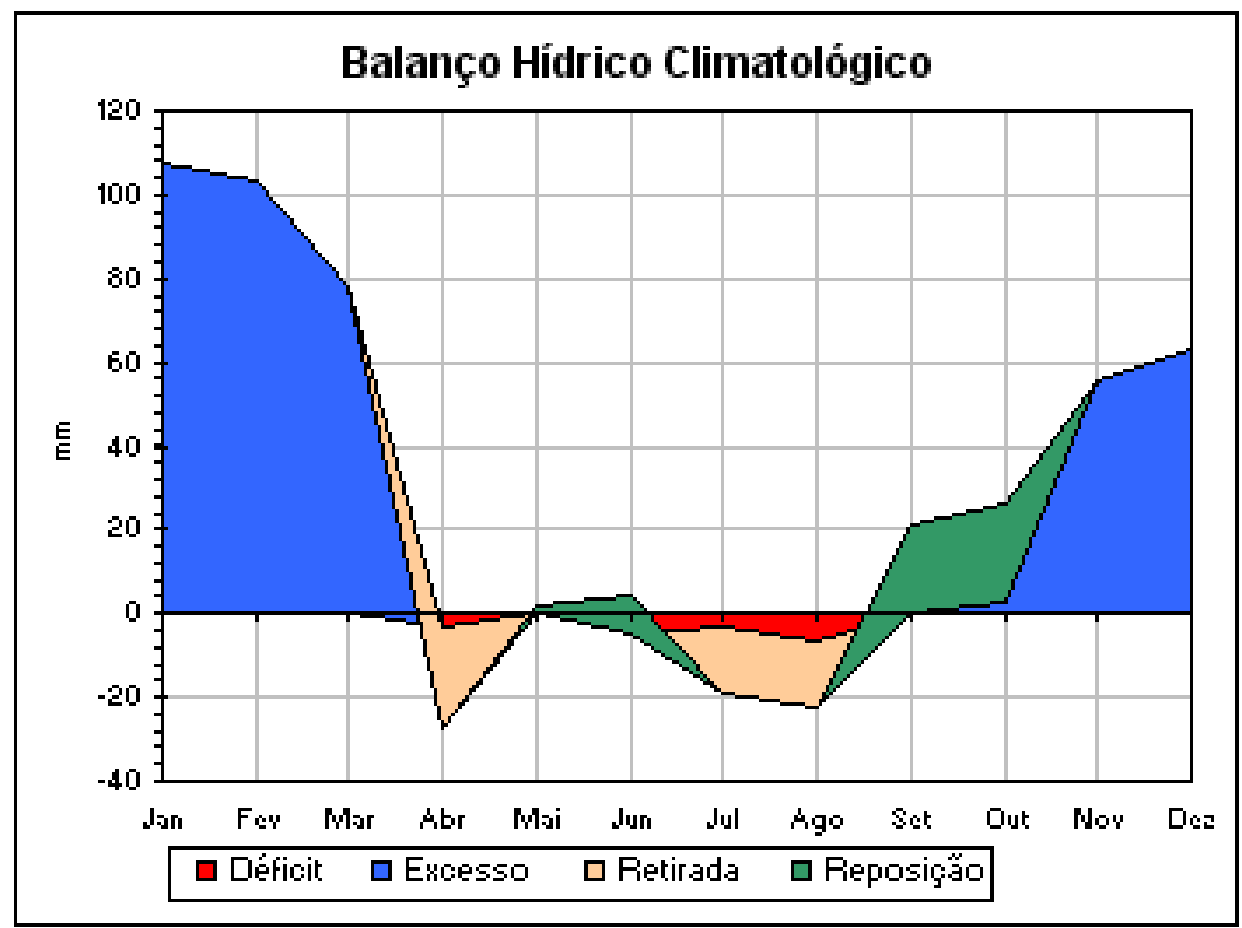

Figura 3. Balanço hídrico multianual, com os dados da Estação Meteorológica do Departamento de Ciências Agrárias da UNITAU, em Taubaté, no período 1992-2003.

Essa metodologia de cálculo do balanço hídrico, proposto por D’Angiolella e Vasconcelos (2002) é viável para períodos multianuais. Mas esses autores disponibilizam, no modelo, o método de Penman (Pereira et al., 1997), que pode ser utilizado para períodos de tempo muito curtos, diários, semanais ou mensais, quando há registros de chuvas nos períodos considerados.

A construção de piezômetros proporcionou medidas diárias de níveis piezométricos do aqüífero freático, obtidas desde novembro de 2005 até janeiro de 2007. Para comparar as oscilações do nível piezométrico do aqüífero freático, com o aporte de água proveniente do excedente hídrico e acompanhamento da recarga natural do aqüífero freático, além do total infiltrado e a quantidade excedente que escoa superficialmente, optou-se por fazer balanços hídricos, utilizando o método de Penman (Pereira et al., 1997), totalizando 3 períodos consecutivos de 60 dias, cada um dividido em 12 frações de 5 dias, compreendendo o período de 16 de novembro de 2005 até 14 de janeiro de 2006, de 15 de janeiro de 2006 a 15 de março de 2006 (Figura 4), e de 16 de março a 15 de maio de 2006.

A partir de maio sucede-se um período seco, sem chuvas, e o espaçamento de tempo obrigatoriamente tem que ser maior para comportar períodos chuvosos, com excedente hídrico. Assim sendo, a partir de 16 de maio até 10 de novembro de 2006, procedeu-se a um balanço hídrico, com duração de 6 meses (180 dias), divididos em frações de 15 dias. $\mathrm{Na}$ Figura 5 é mostrado o balanço hídrico realizado nesse período. 


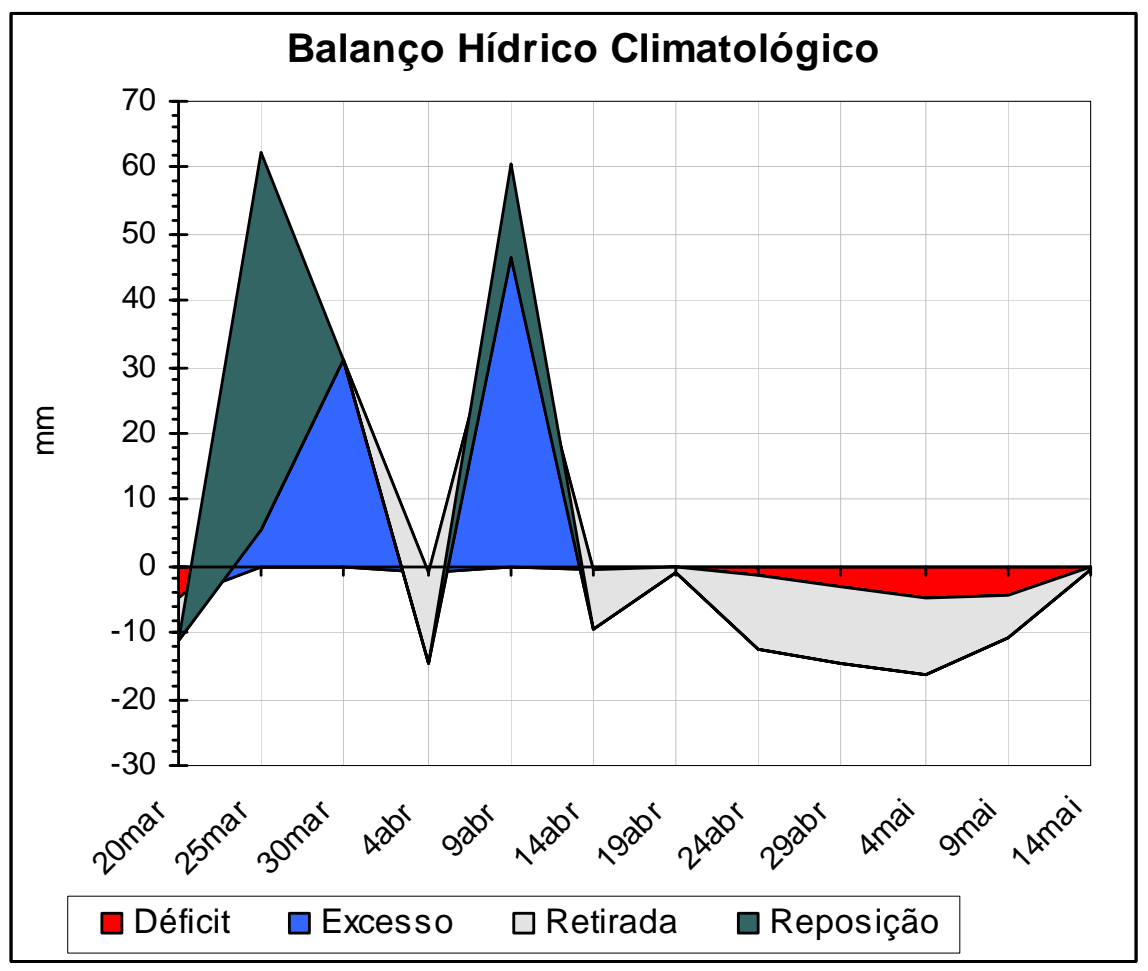

Figura 4. Balanço hídrico multianual, com os dados da Estação Meteorológica do Departamento de Ciências Agrárias da UNITAU, em Taubaté, no período 16 mar. - 14 mai. 2006.

\subsection{Determinação da condutividade hidráulica do solo saturado}

Um dos métodos utilizados para se conhecer a capacidade de infiltração do solo é pela determinação da Condutividade Hidráulica que é máxima quando aquele se encontra saturado.

Existem vários métodos para a determinação da Condutividade Hidráulica $(K)$ de um solo, e entre eles está a realização de ensaios de infiltração ou de bombeamento no aqüífero freático. No caso do aqüífero freático, no local do Departamento de Ciências Agrárias da UNITAU, onde foram instalados piezômetros aos pares, optou-se por realizar um teste infiltrando-se água em um piezômetro, e mediu-se a subida de nível no seu par, ao lado. Para isso, utilizaram-se os piezômetros 5 e 6 , com profundidades de $9,4 \mathrm{~m}$ para a determinação da Condutividade Hidráulica do solo saturado. A distância entre os dois piezômetros é de 0,68 $\mathrm{m}$.

Os dados do teste de infiltração (com duração de 4 h) estão discriminados na Tabela 3. O gráfico com a interpretação do teste é mostrado na Figura 6.

Com o ensaio de infiltração, obteve-se a Transmissividade $(T)$ de $0,09 \mathrm{~m}^{2} / \mathrm{h}$, sabendo-se que $K=T / b$, em que $b$ é a espessura saturada do intervalo ensaiado, antes do início da infiltração (no caso, igual à diferença entre a profundidade do piezômetro e o nível d'água $(9,40 \mathrm{~m}-8,58 \mathrm{~m}=0,82 \mathrm{~m})$.

Assim, $K=0,09 / 0,82=0,11 \mathrm{~m} / \mathrm{h}$ ou $2,64 \mathrm{~m} / \mathrm{dia}$, um valor bastante elevado já que a Condutividade Hidráulica em areias limpas é de $1 \mathrm{~m} /$ dia. Com esse valor de Condutividade Hidráulica $(2,64 \mathrm{~m} /$ dia), o solo mostra alta capacidade de infiltração, tendo sido observado, em algumas pequenas bacias de infiltração construídas na área do Departamento de Ciências Agrárias, rápida absorção das águas acumuladas durante as chuvas. 


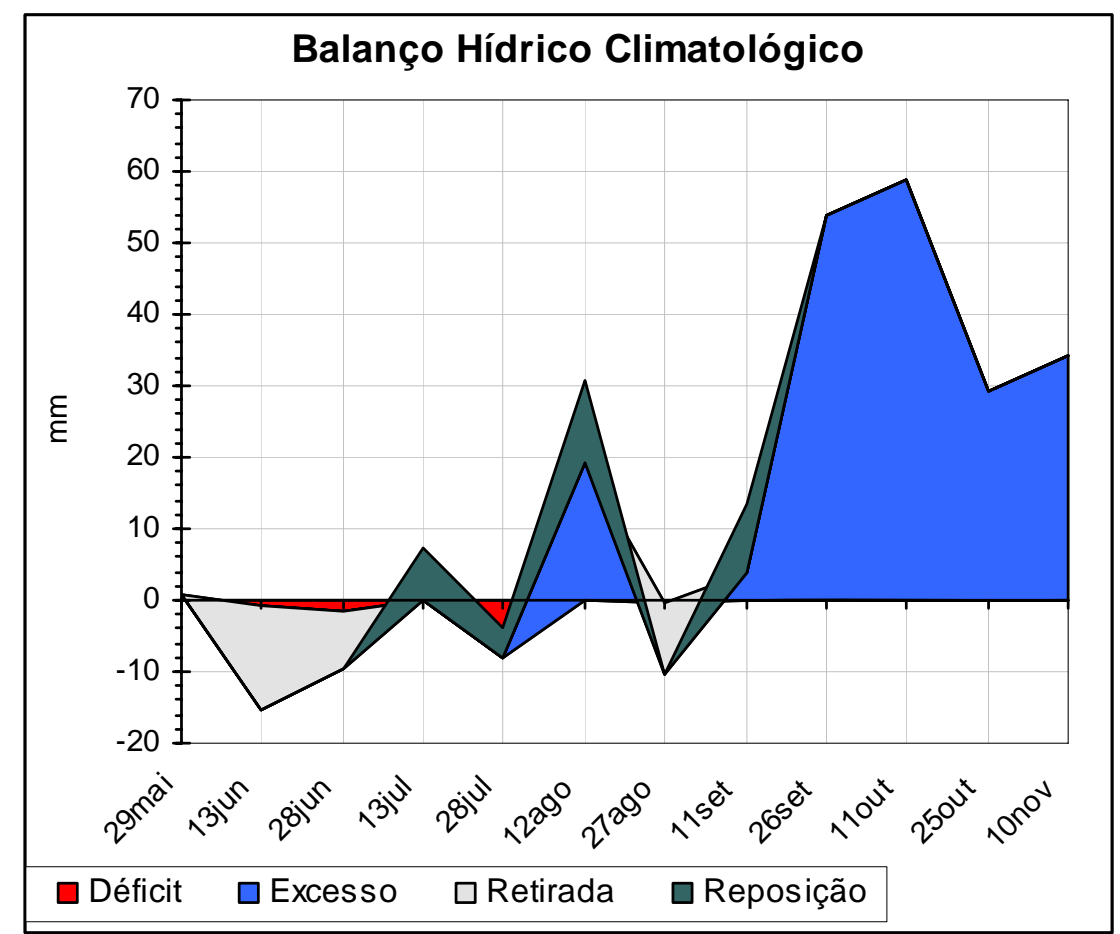

Figura 5. Balanço hídrico multianual, com os dados da Estação Meteorológica do Departamento de Ciências Agrárias da UNITAU, em Taubaté, no período 15 mai. - 10 nov. 06.

Tabela 3. Teste de infiltração realizado em 11/05/2006 nos piezômetros 5 e 6 .

\begin{tabular}{ccccc}
\hline HORA & Tempo (min) & Nível (m) & Recuperação $(\mathbf{m})$ & Vazão $\left(\mathbf{m}^{\mathbf{3}} / \mathbf{h}\right)$ \\
\hline $08: 10$ & 0 & 8,58 & 0,000 & \\
& 1 & 8,46 & 0,120 & 1,012 \\
2 & 8,28 & 0,300 & 1,012 \\
& 4 & 8,00 & 0,580 & 1,012 \\
& 5 & 7,86 & 0,720 & 1,012 \\
& 10 & 7,57 & 1,010 & 1,012 \\
& 20 & 7,22 & 1,360 & 1,012 \\
& 30 & 7,01 & 1,570 & 1,012 \\
& 60 & 6,93 & 1,650 & 1,012 \\
$13: 10$ & 120 & 6,87 & 1,710 & 1,012 \\
& 180 & 6,84 & 1,740 & 1,012 \\
& 240 & 6,80 & 1,780 & 1,012 \\
\hline
\end{tabular}

\subsection{Análises físico-químicas das águas do aqüífero freático}

Essas análises foram realizadas no laboratório da SABESP, Divisão de Controle Sanitário de São José dos Campos. Foram investigados 30 parâmetros, principalmente o conteúdo em metais pesados. Nessas análises, o conteúdo de monocloroamina foi o único orgânico levantado.

$\mathrm{Na}$ Tabela 4, são mostrados os resultados de análises físico-químicas efetuadas em águas coletadas nos piezômetros em 26/04/2006. Os resultados encontrados mostram que, dos 30 parâmetros analisados, cerca de 7 (realçados em amarelo) apresentaram-se acima do limite recomendado pela Portaria 518/2004 do Ministério da Saúde, indicando poluição do solo e do aqüífero freático, no local. 
SANTORO, J.; DINIZ, H. N.; CORREIA, N. T.; CARBONE, F. R.; SCIOTTA L. C. O. Estimativa da recarga do aqüifero freático na bacia do Rio Una, no município de Taubaté, SP. Ambi-Agua, Taubaté, v. 2, n. 1, p. 57-82, 2007. (doi:10.4136/ambi-agua.20)

O ferro dissolvido está presente em níveis acima do permitido em todos os piezômetros. Sua origem provável é conseqüência da alteração intempérica dos minerais ferro-magnesianos

Curva de recuperação do aqüifero freático, no local dos piezômetros 5 e 6

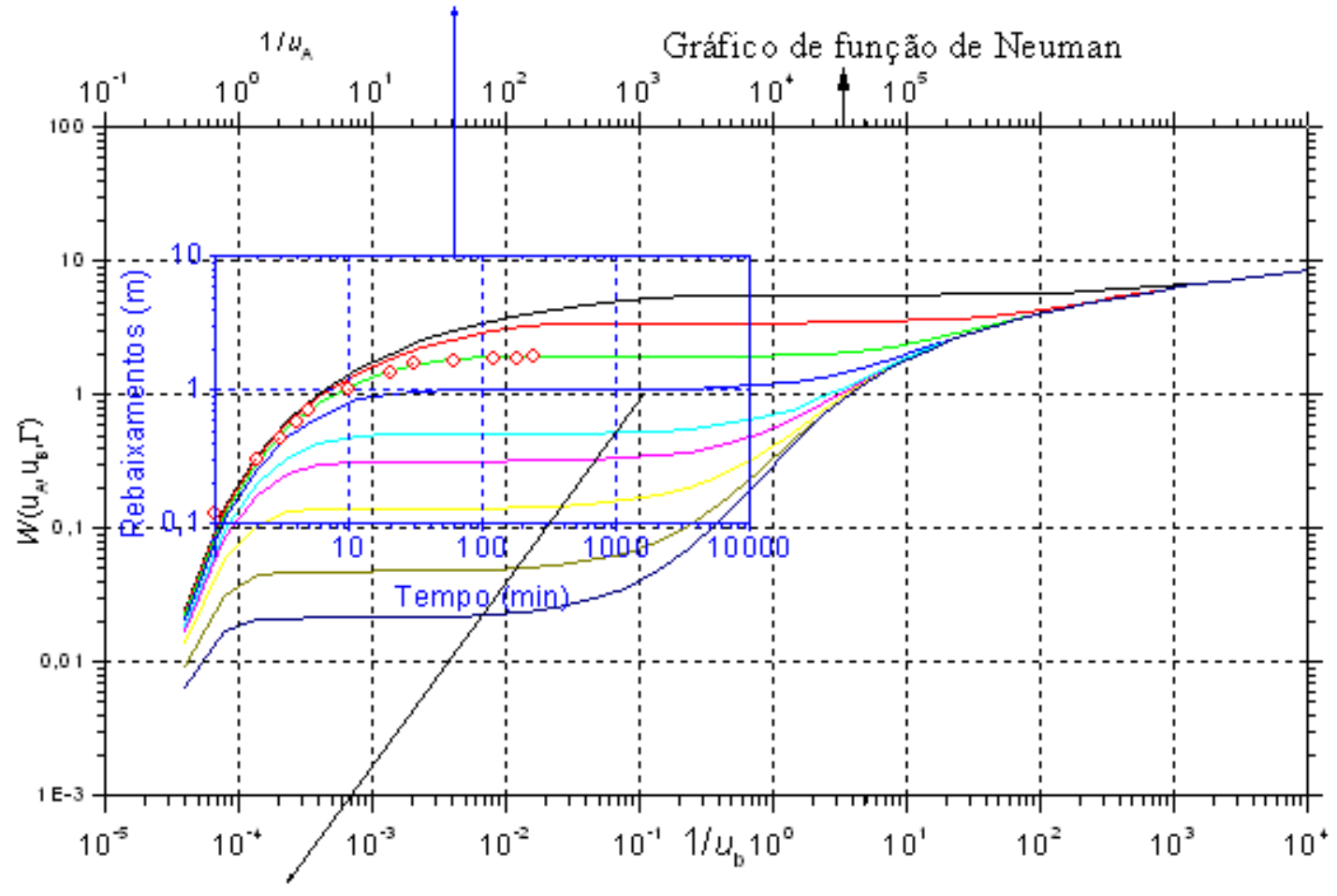

$$
\begin{array}{ll}
\text { Ponto coincidente } & \text { Cálculo da Transmissividade } \\
s=0,91 \mathrm{~m} & Q=1,012 \mathrm{~m}^{3} / \mathrm{h} \\
t=1480 \mathrm{~min} & s=Q \cdot W\left(u_{\mathrm{A}}, u_{\mathrm{B}}, \Gamma\right) / 4 \pi \cdot \mathrm{T} \\
W\left(u_{\mathrm{A}}, u_{\mathrm{B}}, \Gamma\right)=1 & 0,91=1,012 / 4 \pi . \mathrm{T} \\
1 / u_{\mathrm{A}}=1000 & T=0,09 \mathrm{~m}^{2} / \mathrm{h} \\
1 / u_{\mathrm{B}}=0,1 &
\end{array}
$$

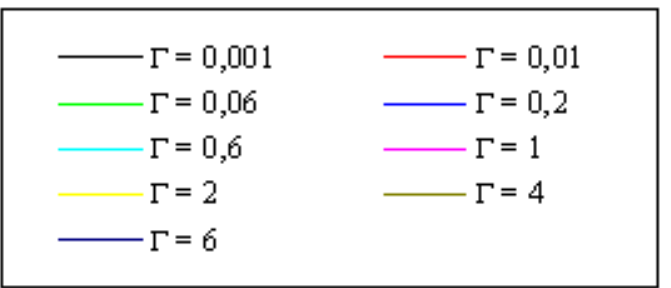

Figura 6. Método da superposição da família de curvas de Neuman (Fetter, 1988) com os dados de rebaixamento $\times$ tempo, obtido no teste de infiltração realizado nos piezômetros 5 e 6 para determinação da Transmissividade do aqüífero freático, no Departamento de Ciências Agrárias da UNITAU.

existentes nas rochas cristalinas, situadas em posição topográfica superior, mas distantes da área ou, então, provenientes da dissolução da montmorilonita, mineral freqüente no substrato constituído por sedimentos terciários da Formação Tremembé. Da mesma forma, o manganês também se encontra acima dos limites. Sua origem é semelhante à do ferro dissolvido. $\mathrm{O}$ teor alto encontrado para estes elementos é atribuído ao particulado coloidal existente nas águas do aqüífero freático já que as análises deles foram realizadas pelo método de Espectrometria de Absorção Atômica (Greenberg et al., 1998), usando amostra total (sem filtração).

Encontrou-se bário acima dos limites no piezômetro 4. É um elemento natural proveniente de sais de bário (barita) existente no cimento nos grãos dos sedimentos terciários da Formação Tremembé, existentes no local, em profundidade.

A primeira avaliação dos resultados das análises das águas coletadas nos piezômetros, no dia 26/04/2006, mostrou que as águas do aqüífero freático, coletadas no piezômetro 4, apresentavam o maior índice de contaminação entre os cinco piezômetros analisados (Tabela 4). Assim sendo, foi realizada uma nova coleta em 23/08/2006 para uma análise química mais 

do aqüifero freático na bacia do Rio Una, no município de Taubaté, SP. Ambi-Agua, Taubaté, v. 2, n. 1, p. 57-82, 2007. (doi:10.4136/ambi-agua.20)

completa nas águas obtidas nesse piezômetro. Desta vez, as análises foram realizadas pelo Laboratório Quimlab, da Universidade do Vale do Paraíba, situado em Jacareí, abrangendo um espectro maior e que atende todos os parâmetros de potabilidade da Portaria 518/2004. Os resultados dessa análise encontram-se nas Tabelas 7,8 e 9, e os parâmetros acima do Limite da Portaria 518/2004 encontram-se realçados em amarelo.

Tabela 4. Resultados das análises químicas realizadas pela SABESP, de São José dos Campos, em amostras coletadas nos piezômetros em 26/04/2006.

\begin{tabular}{|c|c|c|c|c|c|c|c|c|}
\hline \multirow{2}{*}{ Parâmetros } & \multirow{2}{*}{ Unidades } & \multirow{2}{*}{$\begin{array}{l}\text { Limite de } \\
\text { Detecção }\end{array}$} & \multirow{2}{*}{\begin{tabular}{|c} 
Limite Portaria \\
$\mathbf{5 1 8} / \mathbf{2 0 0 4}$
\end{tabular}} & \multicolumn{5}{|c|}{ Piezômetros=profundidades (m) } \\
\hline & & & & $P 1=4,0$ & $P 2=6,0$ & $\mathrm{P3}=5,4$ & $P 4=4,5$ & $P 5=9,4$ \\
\hline Alumínio & $\mathrm{mg} / \mathrm{L}$ & 0,02 & 0,2 & 0,02 & $<0,02$ & 0,03 & $<0,02$ & 0,11 \\
\hline Amônia & $\mathrm{mg} / \mathrm{L}$ & 0,02 & 1,5 & 0,12 & 0,12 & 0,09 & 0,15 & 0,13 \\
\hline Antimônio & $\mathrm{mg} / \mathrm{L}$ & 0,003 & 0,005 & $<0,003$ & $<0,003$ & $<0,003$ & $<0,003$ & $<0,003$ \\
\hline Arsênico & $\mathrm{mg} / \mathrm{L}$ & 0,005 & 0,01 & $<0,005$ & $<0,005$ & $<0,005$ & $<0,005$ & $<0,005$ \\
\hline Bário & $\mathrm{mg} / \mathrm{L}$ & 0,05 & 0,7 & 0,65 & 0,38 & 0,68 & 1,21 & 0,2 \\
\hline Cádmio & $\mathrm{mg} / \mathrm{L}$ & 0,001 & 0,005 & $<0,001$ & $<0,001$ & $<0,001$ & $<0,001$ & $<0,001$ \\
\hline Cianeto & $\mathrm{mg} / \mathrm{L}$ & 0,03 & 0,07 & $<0,03$ & $<0,03$ & $<0,03$ & 0,03 & $<0,03$ \\
\hline Chumbo & $\mathrm{mg} / \mathrm{L}$ & 0,005 & 0,01 & 0,274 & 0,116 & 0,222 & 0,745 & 0,076 \\
\hline Cloreto & $\mathrm{mg} / \mathrm{L}$ & 1 & 250 & 23,01 & $<1$ & 11,88 & $<1$ & $<1$ \\
\hline Cobre & $\mathrm{mg} / \mathrm{L}$ & 0,05 & 2 & 0,06 & $<0,05$ & 0,07 & 0,18 & 0,22 \\
\hline Cond. Especifica & $\mu \mathrm{S} / \mathrm{cm}$ & 0,1 & & 109,9 & 24,2 & 51,5 & 16 & 15,5 \\
\hline Cor Aparente & $\mathrm{UC}$ & 5 & 15 & 3000 & 1250 & 1750 & 5000 & 500 \\
\hline Cromo Total & $\mathrm{mg} / \mathrm{L}$ & 0,005 & 0,05 & 0,053 & 0,027 & 0,059 & 0,15 & 0,031 \\
\hline Ferro & $\mathrm{mg} / \mathrm{L}$ & 0,05 & 0,3 & 105,56 & 42,78 & 103 & 211,6 & 25,18 \\
\hline Fluoreto & $\mathrm{mg} / \mathrm{L}$ & 0,2 & 1,5 & $<0,2$ & $<0,2$ & $<0,2$ & $<0,2$ & $<0,2$ \\
\hline Manganês & $\mathrm{mg} / \mathrm{L}$ & 0,05 & 0,1 & 2,46 & 1,24 & 2,24 & 7,64 & 0,83 \\
\hline Mercúrio & $\mathrm{mg} / \mathrm{L}$ & 0,0002 & 0,001 & $<0,0002$ & $<0,0002$ & $<0,0002$ & $<0,0002$ & $<0,0002$ \\
\hline Monocloramina & $\mathrm{mg} / \mathrm{L}$ & 0,06 & 3 & $<0,06$ & $<0,06$ & $<0,06$ & $<0,06$ & $<0,06$ \\
\hline Nitrato & $\mathrm{mg} / \mathrm{L}$ & 0,05 & 10 & 0,92 & 1,2 & 1,22 & 0,6 & 0,7 \\
\hline Nitrito & $\mathrm{mg} / \mathrm{L}$ & 0,01 & 1 & 0,02 & $<0,01$ & 0,01 & $<0,01$ & $<0,01$ \\
\hline $\mathrm{pH}$ & $\mathrm{pH}$ & & & 4,9 & 5,3 & 5,1 & 5,4 & 5,7 \\
\hline Selênio & $\mathrm{mg} / \mathrm{L}$ & 0,005 & 0,01 & $<0,005$ & $<0,005$ & $<0,005$ & $<0,005$ & $<0,005$ \\
\hline Sódio & $\mathrm{mg} / \mathrm{L}$ & 0,05 & 200 & 4,75 & 2,06 & 1,5 & 1,25 & 0,64 \\
\hline Sulfato & $\mathrm{mg} / \mathrm{L}$ & 2 & 250 & 6,4 & 3,15 & 2,21 & 26,58 & 2,22 \\
\hline Sulfeto & $\mathrm{mg} / \mathrm{L}$ & 0,03 & 0,05 & $<0,03$ & $<0,03$ & $<0,03$ & $<0,03$ & $<0,03$ \\
\hline Surfactantes & $\mathrm{mg} / \mathrm{L}$ & 0,03 & 0,5 & $<0,03$ & $<0,03$ & $<0,03$ & $<0,03$ & $<0,03$ \\
\hline Turbidez & NTU & 0,1 & 5 & 1840 & 780 & 1280 & 4010 & 318 \\
\hline Zinco & $\mathrm{mg} / \mathrm{L}$ & 0,05 & 5 & 0,175 & 0,162 & 0,269 & 0,42 & 0,272 \\
\hline $\begin{array}{l}\text { Sólidos Totais } \\
\text { Dissolvidos }\end{array}$ & $\mathrm{mg} / \mathrm{L}$ & 1 & 1000 & 56 & 11 & 24 & 7 & 7 \\
\hline Temperatura da & & & & & & 24 & 1 & 1 \\
\hline amostra & ${ }^{\circ} \mathrm{C}$ & & & 24 & 24 & 24 & 24 & 24 \\
\hline
\end{tabular}

Obs.: Realçados em amarelo valores acima dos limites da Resolução 518/2004. 


\section{RESULTADOS E DISCUSSÃO}

Para os índices físicos calculados por correlação nas amostras retiradas dos taludes, em diversas profundidades, variáveis entre $0,3 \mathrm{~m}$ e $6 \mathrm{~m}$, obteve-se a média de $53 \%$ de porosidade, $29,3 \%$ de saturação e $70,7 \%$ de aeração (Tabela 5). Verifica-se que esses resultados são bastante coerentes com os resultados obtidos em amostras de solos retiradas em diversos outros pontos do Departamento de Ciências Agrárias da UNITAU, nas profundidades de 0,2 $\mathrm{m}$ e $0,4 \mathrm{~m}$, já que, os valores de porosidade variaram entre 47 e $57 \%$, a saturação entre 30 e $45 \%$ e a aeração entre 55 e $70 \%$ (Tabela 6 ).

Esses valores médios encontrados, Porosidade $(n)$ de $53 \%$ e Grau de Saturação $\left(S_{\mathrm{r}}\right)$ de 29,3\%, foram utilizados para determinar a Capacidade de Armazenamento $\left(C_{a}\right)$ e o Armazenamento Unitário $\left(A_{\mathrm{U}}\right)$, conforme abaixo descrito.

Como, $C_{\mathrm{A}}=\theta-\theta \times \mathrm{S}_{\mathrm{r}}$, então,

$C_{\mathrm{A}}=0,53-0,53 \times 0,293=0,375$.

Sendo, $A_{\mathrm{U}}=1 \mathrm{~m}^{3} \times C_{\mathrm{A}}$, então

$A_{\mathrm{u}}=0,375 \mathrm{~m}^{3}$.

Ou seja, teoricamente, para cada 0,375 m de lâmina d'água infiltrada obter-se-á $1 \mathrm{~m}$ de subida do nível d'água do aqüífero freático. Usa-se a expressão teoricamente porque para cada acréscimo na subida do nível d'água ou aumento do potencial hidráulico haverá, como mecanismo compensatório, um aumento equivalente na descarga da água do aqüífero freático nas fontes.

De qualquer forma, é objetivo deste trabalho comparar o valor encontrado para o Armazenamento Unitário com as medidas diárias de variações dos níveis d'água nos piezômetros para se conhecer a recarga natural do aqüífero freático no local do Departamento de Ciências Agrárias da UNITAU e, também, as taxas de descarga nas fontes que vão alimentar o fluxo de base do ribeirão Itaim.

Tabela 5. Resultados dos índices físicos calculados por correlação com os parâmetros obtidos nas amostras dos taludes (profundidade de 0,3 a $6 \mathrm{~m}$ ).

\begin{tabular}{|c|c|c|c|c|c|c|c|c|c|c|c|}
\hline Talude & $\begin{array}{l}\text { Posição e } \\
\text { profund. }\end{array}$ & \begin{tabular}{|c|} 
Coord. \\
UTM EW \\
(m) \\
\end{tabular} & $\begin{array}{c}\text { Coord. } \\
\text { UTM NS } \\
(\mathrm{m})\end{array}$ & $\begin{array}{c}\text { Cota } \\
\text { (m) }\end{array}$ & $\begin{array}{c}\gamma_{\mathrm{s}} \\
\left(\mathrm{g} / \mathrm{cm}^{3}\right)\end{array}$ & $\begin{array}{c}w \\
(\%)\end{array}$ & $\begin{array}{c}\gamma \\
\left(\mathrm{g} / \mathrm{cm}^{3}\right)\end{array}$ & $e$ & $n(\%)$ & $\operatorname{Sr}(\%)$ & $A(\%)$ \\
\hline \multirow{3}{*}{1} & Topo $-2 \mathrm{~m}$ & \multirow{3}{*}{447996} & \multirow{3}{*}{7452971} & \multirow{3}{*}{590} & 2,68 & 12,9 & 1,383 & 1,188 & 54,3 & 29,1 & 70,9 \\
\hline & Meio $-4 \mathrm{~m}$ & & & & 2,65 & 7,9 & 1,518 & 0,884 & 46,9 & 28,0 & 72,0 \\
\hline & Base $-6 \mathrm{~m}$ & & & & 2,64 & 9,6 & 1,449 & 0,999 & 50,0 & 25,4 & 74,6 \\
\hline \multirow{3}{*}{2} & Topo $-3 \mathrm{~m}$ & \multirow{3}{*}{447938} & \multirow{3}{*}{7452776} & \multirow{3}{*}{591} & 2,64 & 5,7 & 1,449 & 0,862 & 46,3 & 17,5 & 82,5 \\
\hline & Meio $-4,5 \mathrm{~m}$ & & & & 2,67 & 12,9 & 1,417 & 1,118 & 52,8 & 29,6 & 70,4 \\
\hline & Base $-6 \mathrm{~m}$ & & & & 2,65 & 11 & 1,429 & 1,058 & 51,4 & 27,6 & 72,4 \\
\hline \multirow{3}{*}{3} & Topo $-0,3 \mathrm{~m}$ & \multirow{3}{*}{447829} & \multirow{3}{*}{7452670} & \multirow{3}{*}{578} & 2,65 & 20 & 1,395 & 1,28 & 56,1 & 41,4 & 58,6 \\
\hline & Meio $-1,5 \mathrm{~m}$ & & & & 2,67 & 17,3 & 1,278 & 1,451 & 59,2 & 31,8 & 68,16 \\
\hline & Base $-3 \mathrm{~m}$ & & & & 2,66 & 18,7 & 1,265 & 1,496 & 59,9 & 33,6 & 66,75 \\
\hline \multicolumn{9}{|c|}{ Média } & 53 & 29,3 & 70,7 \\
\hline
\end{tabular}

Verificou-se que, na amostra coletada a $1 \mathrm{~m}$ de profundidade, as areias mostram uma distribuição uniforme entre areia muito fina até areia média (Figura 7) e, na amostra coletada a $2 \mathrm{~m}$ de profundidade, as areias mostram uma distribuição muito uniforme desde muito fina até grossa (Figura 8). Isso demonstra uma característica encontrada nos solos da Faculdade de Agronomia: baixo grau de seleção em profundidade, ou seja, quanto maior a profundidade 
SANTORO, J.; DINIZ, H. N.; CORREIA, N. T.; CARBONE, F. R.; SCIOTTA L. C. O. Estimativa da recarga do aqüifero freático na bacia do Rio Una, no município de Taubaté, SP. Ambi-Agua, Taubaté, v. 2, n. 1, p. 57-82, 2007. (doi:10.4136/ambi-agua.20)

mais uniforme é a distribuição da textura dos sedimentos, desde finos, argilosos, até grossos, arenosos.

Tabela 6. Resultado dos índices físicos calculados por correlação com os parâmetros obtidos nas amostras de campo da Faculdade de Agronomia da UNITAU (prof. 0 a 0,4 m).

\begin{tabular}{|c|c|c|c|c|c|c|c|c|c|c|c|}
\hline Ponto & $\begin{array}{l}\text { Profund. } \\
\text { (m) }\end{array}$ & $\begin{array}{l}\text { Coord. } \\
\text { UTM EW } \\
\text { (m) }\end{array}$ & $\begin{array}{c}\text { Coord. } \\
\text { UTM NS } \\
(\mathrm{m})\end{array}$ & $\begin{array}{c}\text { Cota } \\
\text { (m) }\end{array}$ & $\begin{array}{c}\gamma_{\mathrm{s}} \\
\left(\mathrm{g} / \mathrm{cm}^{3}\right)\end{array}$ & $w(\%)$ & $\begin{array}{c}\gamma \\
\left(g / \mathbf{c m}^{3}\right)\end{array}$ & $e$ & $\begin{array}{c}n \\
(\%)\end{array}$ & $\begin{array}{c}S r \\
(\%) r\end{array}$ & $A(\%)$ \\
\hline 1 & 0,20 & 447040 & 7452930 & 580 & 2,79 & 15,71 & 1,47 & 1,20 & 54 & 37 & 63 \\
\hline 2 & 0,20 & 446991 & 7452890 & 572 & 2,86 & 14,09 & 1,40 & 1,32 & 57 & 30 & 70 \\
\hline 3 & 0,20 & 447027 & 7452914 & 577 & 2,68 & 16,45 & 1,57 & 0,99 & 50 & 45 & 55 \\
\hline 4 & 0,20 & 447006 & 7452930 & 575 & 2,60 & 12,80 & 1,55 & 0,89 & 47 & 37 & 63 \\
\hline 5 & 0,20 & 447059 & 7452801 & 567 & 2,64 & 16,01 & 1,40 & 1,20 & 54 & 35 & 65 \\
\hline 6 & 0,20 & 447082 & 7452893 & 568 & 2,82 & 16,55 & 1,42 & 1,31 & 57 & 36 & 64 \\
\hline 1 & 0,40 & 447040 & 7452930 & 580 & 2,93 & 17,38 & 1,50 & 1,30 & 56 & 39 & 61 \\
\hline 2 & 0,40 & 446991 & 7452890 & 572 & 2,76 & 13,24 & 1,52 & 1,05 & 51 & 35 & 65 \\
\hline 3 & 0,40 & 447027 & 7452914 & 577 & 2,69 & 14,81 & 1,56 & 0,98 & 49 & 41 & 59 \\
\hline 4 & 0,40 & 447006 & 7452930 & 575 & 2,72 & 15,50 & 1,63 & 0,93 & 48 & 45 & 55 \\
\hline 5 & 0,40 & 447059 & 7452801 & 567 & 2,78 & 14,30 & 1,58 & 1,01 & 50 & 39 & 61 \\
\hline 6 & 0,40 & 447082 & 7452893 & 568 & 2,86 & 13,48 & 1,56 & 1,08 & 52 & 36 & 64 \\
\hline
\end{tabular}

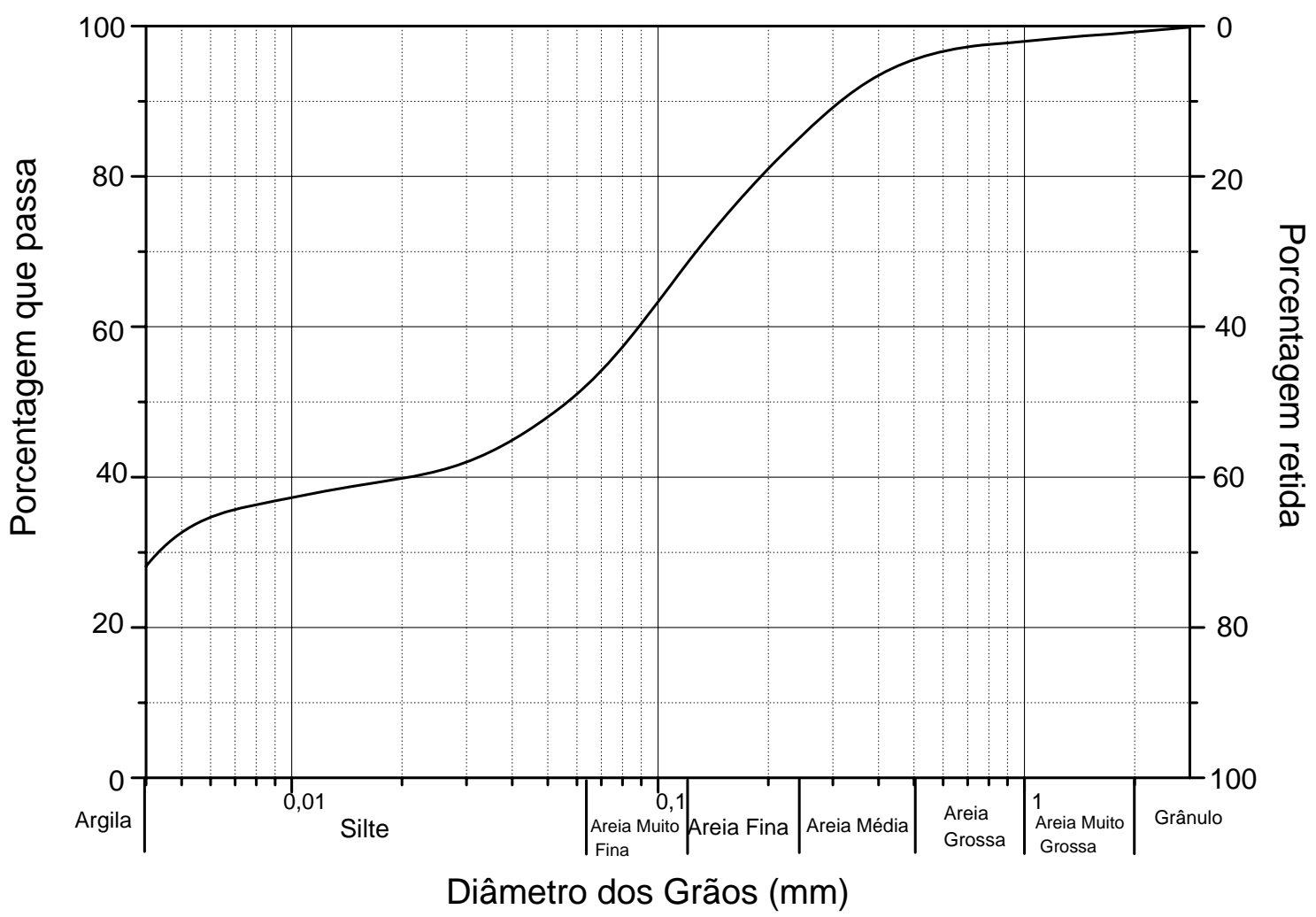

Figura 7. Curva granulométrica da amostra de $1 \mathrm{~m}$ profundidade do Piezômetro 1, do Departamento de Ciências Ambientais da UNITAU. 
SANTORO, J.; DINIZ, H. N.; CORREIA, N. T.; CARBONE, F. R.; SCIOTTA L. C. O. Estimativa da recarga do aqüifero freático na bacia do Rio Una, no município de Taubaté, SP. Ambi-Agua, Taubaté, v. 2, n. 1, p. 57-82, 2007. (doi:10.4136/ambi-agua.20)

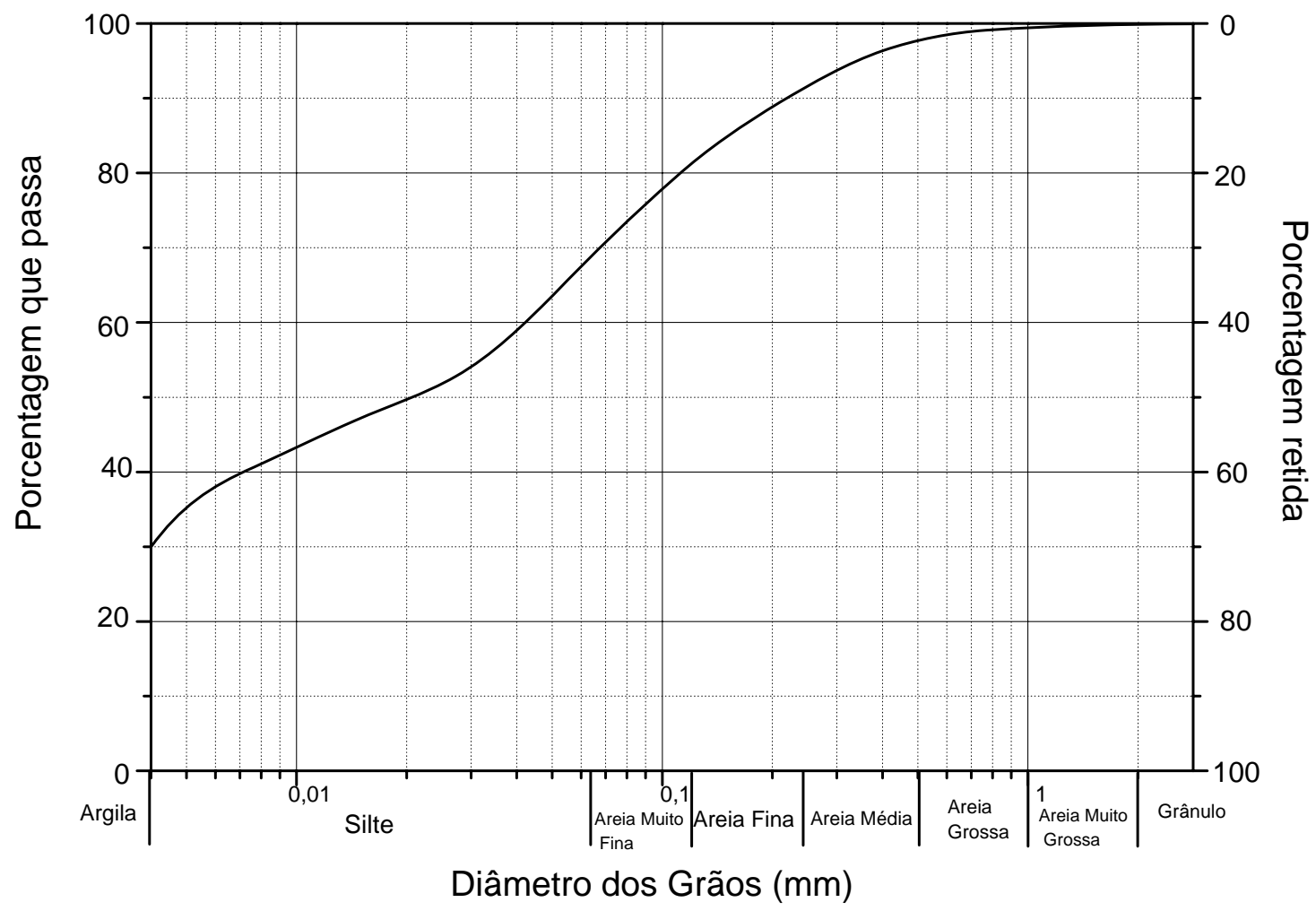

Figura 8. Curva granulométrica da amostra $2 \mathrm{~m}$ de profundidade do Piezômetro 1, do Departamento de Ciências Ambientais da UNITAU.

\subsection{Avaliação da recarga natural}

Como foi visto anteriormente, baseado nos índices físicos, para cada $0,375 \mathrm{~m}$ de lâmina d'água infiltrada tem-se $1 \mathrm{~m}$ de subida do nível d'água do aqüífero freático.

Sabendo-se o excesso de água disponível no perfil do solo pelo cálculo do balanço hídrico (realizado em três períodos consecutivos de 60 dias, de 16 de novembro de 2005 a 15 de maio de 2006, em um período de 180 dias, de 16 de maio de 2006 a 10 de novembro de 2006 e, em um período de 60 dias, de 11 de novembro de 2006 a 4 de janeiro de 2007) e conhecendo as variações do nível d'água do aqüífero freático, medidas nos piezômetros por comparação, pode-se estimar a recarga natural e saber como ela ocorre em função das chuvas.

Observou-se que, no piezômetro 1, nenhuma medida do nível d'água é inferior ao Datum $-3,46 \mathrm{~m}$ abaixo do nível do solo. Assim, o gráfico da Figura 9 foi confeccionado adotando-se o Datum -3,46 m abaixo do solo no local do Piezômetro 1, como nível zero e assim, para que as oscilações do nível d'água sempre sejam positivas em relação ao Datum, todas as medidas históricas do nível d'água obtidas foram subtraídas de 3,46 m. O gráfico da variação do nível d'água, no tempo (em linha, em vermelho), disposto junto com o gráfico das precipitações (em colunas, em verde), mostra que, após o início do período chuvoso, a partir de novembro, o nível d'água do aqüífero freático sobe continuamente e rapidamente, atingindo o nível máximo no dia 18 de fevereiro de 2006. Após essa data, há um período de recessão curto e com forte abatimento do nível, que dura até 8 de março de 2006.

Traçando-se a reta média nesse período curto (Figura 9), obtém-se um coeficiente angular de $38,75 \mathrm{~mm} /$ dia que corresponde a $14,53 \mathrm{~mm} /$ dia de queda da altura da lâmina d'água contida no aqǘ́fero freático (igual a 38,75 dividido por 0,375 ), considerando que, para cada $0,375 \mathrm{~m}$ de lâmina d'água infiltrada, o nível d'água do aqüífero sobe $1 \mathrm{~m}$ de altura (conforme descrito anteriormente). Esse é o valor da taxa de descarga de água armazenada no 
aqüífero freático, nas fontes onde há exudação, no período considerado, quando o potencial hidráulico é alto (maior que 0,6 m acima do Datum 3,46 m, conforme pode ser visto no gráfico da Figura 9). Essa taxa mostra que a descarga média da água do aqüífero freático nas fontes (para essa altura de potencial hidráulico) é de $1 \mathrm{~m}^{3} /$ dia para cada área de 79,8 $\mathrm{m}^{2}$ do terreno. Enquanto há infiltração de água das chuvas, até 23/4/2006, o nível d'água se mantém praticamente constante, ou seja, a perda de água nas fontes se iguala à água infiltrada proveniente das precipitações.

De 23/04/2006 a 27/07/2006, ocorre um longo período de recessão. Traçando-se a reta média nesse período (quando as medidas são inferiores ao potencial hidráulico de $0,6 \mathrm{~m}$ acima do Datum 3,46 m, conforme pode ser visto no gráfico da Figura 9), obtém-se o coeficiente angular igual a 4,92 mm/dia. Considerando que, para cada 0,375 $\mathrm{m}$ de lâmina d'água infiltrada, ocorre $1 \mathrm{~m}$ de subida do nível d'água, resulta em 1,85 mm/dia de taxa de recessão da lâmina d'água no aqüífero freático, em média (igual a 4,92 dividido por 0,375). Esta é a taxa de descarga da água armazenada no aqüífero freático, nas fontes de exudação, durante o período seco. Essa taxa mostra que a descarga média da água do aqüífero freático nas fontes, nesse período, é de $1 \mathrm{~m}^{3} /$ dia para cada área com $540,5 \mathrm{~m}^{2}$ do terreno.

O gráfico em linha (violeta) da Figura 9 representa as medidas equivalentes de excedente hídrico no perfil do solo, considerando que, para cada $0,375 \mathrm{~m}$ de lâmina d'água excedente, o nível d'água do aqüífero freático sobe $1 \mathrm{~m}$. Quando os pontos em azul escuro estão acima do nível d'água, conclui-se que há escoamento superficial (igual à diferença entre o ponto considerado, em azul escuro, e o ponto situado abaixo, na vertical, na curva do nível d'água, em vermelho, dividido pelo fator $0,375 \mathrm{~m}$ ).

Nos períodos situados entre 12 de outubro e 5 de novembro, e entre 16 de novembro e 15 de dezembro, o nível d'água do aqǘfero freático (linha em vermelho) sobe mais do que há água disponível no balanço hídrico (linha em violeta). Verifica-se que, é justamente nesses períodos (final do período seco e início do período chuvoso), quando há germinação das culturas, há máxima recarga do aqüífero freático (recarga artificial involuntária) devido ao lançamento, por aspersão, da água bombeada do ribeirão Itaim nas plantações experimentais da Faculdade de Agronomia situadas a montante da área onde estão instalados os piezômetros.

Como esse é um fator de recarga efêmero, a subida do nível d'água é rápida assim como o seu descenso.

\subsection{Contaminação das águas do aqüífero freático}

Os resultados das análises bacteriológicas são preocupantes na região, pois no piezômetro 4 foram encontrados índices elevados da bactéria Escherichia Coli (Tabela 7), um coliforme fecal. A presença de bactérias fecais no piezômetro 4 a $4,5 \mathrm{~m}$ de profundidade indica que o aqüífero freático é muito vulnerável na região, pois o solo possui alta porosidade (53\%, em média), e horizontes predominantemente franco-arenosos, com pouca argila para adsorver ou absorver poluentes e/ou bactérias que migram facilmente até o aqüífero freático juntamente com a água que percola o solo advinda das chuvas ou, do ribeirão Itaim, bombeada para irrigar as culturas existentes na Faculdade de Agronomia da UNITAU durante o período de germinação.

A análise química detalhada do piezômetro 4 mostra as condições das águas subterrâneas do aqüífero freático. A cor e turbidez elevada demonstram que há muitos sólidos nessas águas, a maior parte em estado coloidal. $\mathrm{O}$ teor alto de ferro em relação a outros elementos mostra que esses sólidos coloidais são constituídos, preferencialmente, por óxidos e hidróxidos de ferro e, em menor quantidade, por óxidos e hidróxidos de manganês. 
O teor relativamente alto de sulfatos, entre os ânions analisados, mostra que entre os compostos de ferro estão incluídos, também, alguns sulfatos (constituindo parte da fração coloidal). O gráfico da Figura 11 mostra que somente uma quantidade pequena de sulfatos encontra-se dissolvida (para que haja equilíbrio entre os cátions e ânions presentes), sendo que, a maior parte provavelmente encontra-se como compostos de ferro e manganês.

Metais como o chumbo e bário também estão presentes, e os seus pesos atômicos elevados mostram que somente podem estar sendo transportados como parte da massa coloidal. O teor de dureza mostra que também existem, nessa massa, carbonatos de cálcio. Sulfatos de chumbo e carbonatos de bário, em estado iônico, também devem estar presentes em pequena quantidade, já que os seus índices de dissolução são baixos.

A presença de bactérias (coliformes fecais e totais) indica que elas são transportadas junto com os colóides e sobrevivem no solo até a profundidade de $4,5 \mathrm{~m}$, ao menos, já que o piezômetro 4 atinge essa profundidade.

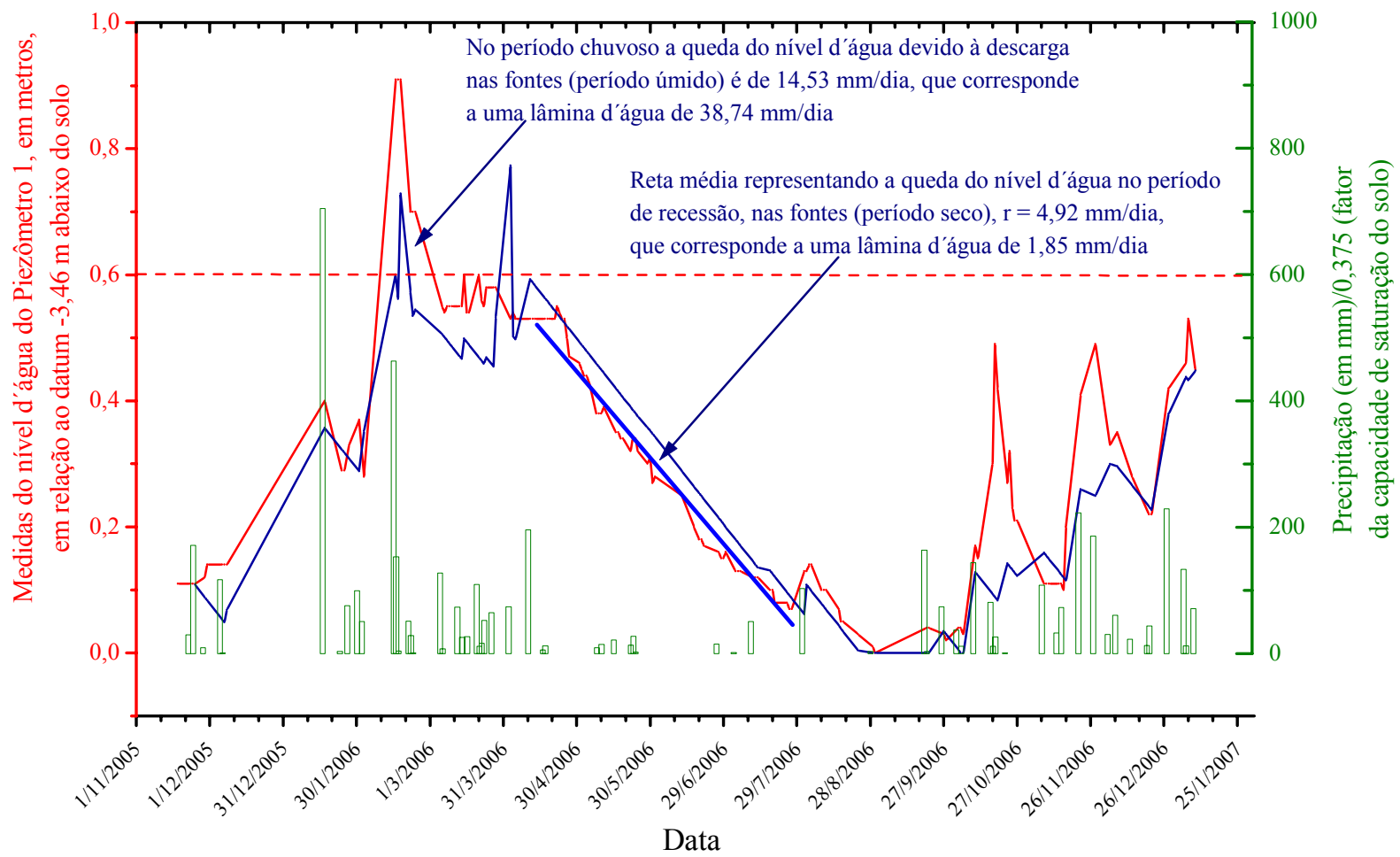

Figura 9. Gráfico das medidas do nível d'água no Piezômetro 1 (linha, em vermelho), precipitação (colunas, em verde) e alturas equivalentes do nível d'água, considerando os dados do balanço hídrico (linha, em violeta), no Departamento de Ciências Agrárias da UNITAU, no período 1nov2005-25 jan. 2007.

Embora a área do Departamento de Ciências Agrárias da UNITAU tenha sido utilizada para fins agrícolas há bastante tempo, e de forma metódica há pelo menos 30 anos, não há vestígios de agrotóxicos ou desinfetantes nas águas do aqüífero freático (Tabelas 8 e 9). Da mesma forma, existe uma pista para pouso e decolagem de helicópteros e aviões do Exército Brasileiro, em uma área vizinha ao Departamento de Ciências Agrárias, na Base Aérea da Aviação do Exército (BAVEX) e, mesmo assim, apesar do uso freqüente de hidrocarbonetos (combustíveis) e solventes, não há vestígios de orgânicos nas águas subterrâneas do aqüífero freático (Tabela 9). Esses fatos mostram que, embora as camadas de solo que contêm o 
SANTORO, J.; DINIZ, H. N.; CORREIA, N. T.; CARBONE, F. R.; SCIOTTA L. C. O. Estimativa da recarga do aqüifero freático na bacia do Rio Una, no município de Taubaté, SP. Ambi-Agua, Taubaté, v. 2, n. 1, p. 57-82, 2007. (doi:10.4136/ambi-agua.20)

aqüífero freático sejam bastante porosas e permeáveis, permitindo inclusive a sobrevivência de bactérias, elas possuem um poder depurativo bastante efetivo quanto aos pesticidas, adubos e materiais orgânicos.

Tabela 7. Análise físico-química e bacteriológica realizada com amostra de água coletada no piezômetro 4, em 23/08/2006.

\begin{tabular}{|c|c|c|c|c|}
\hline PARÂMETROS & UNIDADES & $\begin{array}{c}\text { Limite de } \\
\text { detecção }\end{array}$ & $\begin{array}{c}\text { Limite Portaria } \\
518 / 2004\end{array}$ & Piezômetro 4 - Prof. $4,5 \mathrm{~m}$ \\
\hline \multicolumn{5}{|l|}{$\begin{array}{c}\text { Características } \\
\text { físicas }\end{array}$} \\
\hline Temperatura & ${ }^{\circ} \mathrm{C}$ & - & - & 24 \\
\hline $\mathrm{pH}$ & $\mathrm{pH}$ & - & - & 5,4 \\
\hline $\begin{array}{c}\text { Condutividade } \\
\text { Especifica }\end{array}$ & $\mu \mathrm{S} / \mathrm{cm}$ & 0,1 & - & 16 \\
\hline $\begin{array}{c}\text { Sólidos Totais } \\
\text { Dissolvidos }\end{array}$ & $\mathrm{mg} / \mathrm{L}$ & 1 & 1000 & 7 \\
\hline Cor Aparente & $\mathrm{UC}$ & 5 & 15 & 5000 \\
\hline Turbidez & NTU & 0,1 & 5 & 4010 \\
\hline \multicolumn{5}{|l|}{ Metais } \\
\hline Alumínio & $\mathrm{mg} / \mathrm{L}$ & 0,02 & 0,2 & $<0,02$ \\
\hline Bário & $\mathrm{mg} / \mathrm{L}$ & 0,05 & 0,7 & 1,21 \\
\hline Cádmio & $\mathrm{mg} / \mathrm{L}$ & 0,001 & 0,005 & $<0,001$ \\
\hline Chumbo & $\mathrm{mg} / \mathrm{L}$ & 0,005 & 0,01 & 0,745 \\
\hline Cobre & $\mathrm{mg} / \mathrm{L}$ & 0,05 & 2 & 0,18 \\
\hline Cromo Total & $\mathrm{mg} / \mathrm{L}$ & 0,005 & 0,05 & 0,15 \\
\hline Ferro & $\mathrm{mg} / \mathrm{L}$ & 0,05 & 0,3 & 211,6 \\
\hline Manganês & $\mathrm{mg} / \mathrm{L}$ & 0,05 & 0,1 & 7,64 \\
\hline Mercúrio & $\mathrm{mg} / \mathrm{L}$ & 0,0002 & 0,001 & $<0,0002$ \\
\hline Zinco & $\mathrm{mg} / \mathrm{L}$ & 0,05 & 5 & $<0,05$ \\
\hline \multicolumn{5}{|l|}{ Semimetais } \\
\hline Antimônio & $\mathrm{mg} / \mathrm{L}$ & 0,003 & 0,005 & $<0,003$ \\
\hline Arsênico & $\mathrm{mg} / \mathrm{L}$ & 0,005 & 0,01 & $<0,005$ \\
\hline \multicolumn{5}{|l|}{ Ametais } \\
\hline Fluoreto & $\mathrm{mg} / \mathrm{L}$ & 0,2 & 1,5 & $<0,2$ \\
\hline Selênio & $\mathrm{mg} / \mathrm{L}$ & 0,005 & 0,01 & $<0,005$ \\
\hline Sulfeto & $\mathrm{mg} / \mathrm{L}$ & 0,03 & 0,05 & $<0,03$ \\
\hline \multicolumn{5}{|l|}{ Bactérias } \\
\hline Coliformes Totais & $\mathrm{NMP} / 100 \mathrm{ml}$ & 1 & 0 & 25 \\
\hline Escherichia Coli & $\mathrm{NMP} / 100 \mathrm{ml}$ & 1 & 0 & 25 \\
\hline
\end{tabular}

Obs.: Realçados em amarelo valores acima dos limites da Resolução 518/2004. 
Tabela 8. Análises de compostos e agrotóxicos realizadas com amostras de água coletadas no piezômetro 4, em 23/08/2006.

\begin{tabular}{|c|c|c|c|c|}
\hline PARÂMETROS & UNIDADES & $\begin{array}{c}\text { Limite de } \\
\text { detecção }\end{array}$ & $\begin{array}{c}\text { Limite Portaria } \\
518 / 2004 \\
\end{array}$ & Piezômetro 4 - Prof. 4,5 m \\
\hline \multicolumn{5}{|l|}{ Compostos } \\
\hline Amônia & $\mathrm{mg} / \mathrm{L}$ & 0,02 & 1,5 & 0,27 \\
\hline Dureza Total & $\mathrm{mg} / \mathrm{L}$ & - & 500 & 14,3 \\
\hline Cianeto & $\mathrm{mg} / \mathrm{L}$ & 0,03 & 0,07 & $<0,03$ \\
\hline Nitrito & $\mathrm{mg} / \mathrm{L}$ & 0,01 & 1 & $<0,01$ \\
\hline Sílica & $\mathrm{mg} / \mathrm{L}$ & - & - & 3 \\
\hline Surfactantes & $\mathrm{mg} / \mathrm{L}$ & 0,03 & 0,5 & $<0,03$ \\
\hline \multicolumn{5}{|l|}{ Agrotóxicos } \\
\hline Alaclor & $\mu \mathrm{g} / \mathrm{L}$ & - & 20 & $<1$ \\
\hline Aldrin e Dieldrin & $\mu \mathrm{g} / \mathrm{L}$ & - & 0,03 & $<0,01$ \\
\hline Atrazina & $\mu \mathrm{g} / \mathrm{L}$ & - & 2 & $<1$ \\
\hline Bentazona & $\mu \mathrm{g} / \mathrm{L}$ & - & 300 & $<10$ \\
\hline $\begin{array}{l}\text { Clordano } \\
\text { (Isômeros) }\end{array}$ & $\mu \mathrm{g} / \mathrm{L}$ & - & 0,2 & $<0,1$ \\
\hline $2,4 \mathrm{D}$ & $\mu \mathrm{g} / \mathrm{L}$ & - & 30 & $<5$ \\
\hline DDT(Isômeros) & $\mu \mathrm{g} / \mathrm{L}$ & - & 2 & $<0,5$ \\
\hline Endossulfan & $\mu \mathrm{g} / \mathrm{L}$ & - & 20 & $<3$ \\
\hline Endrin & $\mu \mathrm{g} / \mathrm{L}$ & - & 0,6 & $<0,1$ \\
\hline Glifosato & $\mu \mathrm{g} / \mathrm{L}$ & - & 500 & $<10$ \\
\hline $\begin{array}{l}\text { Heptacloro e Hep- } \\
\text { tacloro epoxido }\end{array}$ & $\mu \mathrm{g} / \mathrm{L}$ & - & 0,03 & $<0,01$ \\
\hline Hexaclorobenzeno & $\mu \mathrm{g} / \mathrm{L}$ & - & 1 & $<0,5$ \\
\hline Lindano( g-BHC) & $\mu \mathrm{g} / \mathrm{L}$ & - & 2 & $<0,5$ \\
\hline Metolacloro & $\mu \mathrm{g} / \mathrm{L}$ & - & 10 & $<3$ \\
\hline Molinato & $\mu \mathrm{g} / \mathrm{L}$ & - & 6 & $<2$ \\
\hline Metoxicloro & $\mu \mathrm{g} / \mathrm{L}$ & - & 20 & $<5$ \\
\hline Pendimetalina & $\mu \mathrm{g} / \mathrm{L}$ & - & 20 & $<5$ \\
\hline Pentaclorofenol & $\mu \mathrm{g} / \mathrm{L}$ & - & 9 & $<2$ \\
\hline Permetrina & $\mu \mathrm{g} / \mathrm{L}$ & - & 20 & $<6$ \\
\hline Propanil & $\mu \mathrm{g} / \mathrm{L}$ & - & 20 & $<4$ \\
\hline Simazina & $\mu \mathrm{g} / \mathrm{L}$ & - & 2 & $<1$ \\
\hline Trifluralina & $\mu \mathrm{g} / \mathrm{L}$ & - & 20 & $<5$ \\
\hline
\end{tabular}


Tabela 9. Análises dos orgânicos, desinfetantes, cátions e ânions principais em amostras de água coletadas no piezômetro 4, em 23/08/2006.

\begin{tabular}{|c|c|c|c|c|}
\hline PARÂMETROS & UNIDADES & $\begin{array}{c}\text { Limite de } \\
\text { detecção }\end{array}$ & $\begin{array}{c}\text { Limite Portaria } \\
518 / 2004 \\
\end{array}$ & \begin{tabular}{|c|} 
Piezômetro 4 - \\
Prof. 4,5 m \\
\end{tabular} \\
\hline \multicolumn{5}{|l|}{ Orgânicos } \\
\hline Acrilamida & $\mu \mathrm{g} / \mathrm{L}$ & - & 0,5 & $<0,1$ \\
\hline Benzeno & $\mu \mathrm{g} / \mathrm{L}$ & - & 5 & $<0,5$ \\
\hline Benzo(a)Pireno & $\mu \mathrm{g} / \mathrm{L}$ & - & 0,7 & $<0,1$ \\
\hline Cloreto de Vinila & $\mu \mathrm{g} / \mathrm{L}$ & - & 5 & $<1$ \\
\hline 1,2 Dicloroetano & $\mu \mathrm{g} / \mathrm{L}$ & - & 10 & $<2$ \\
\hline 1,1 Dicloroeteno & $\mu \mathrm{g} / \mathrm{L}$ & - & 30 & $<5$ \\
\hline Diclorometano & $\mu \mathrm{g} / \mathrm{L}$ & - & 20 & $<5$ \\
\hline Estireno & $\mu \mathrm{g} / \mathrm{L}$ & - & 20 & $<1$ \\
\hline Tetracloreto de Carbono & $\mu \mathrm{g} / \mathrm{L}$ & - & 2 & $<1$ \\
\hline Tetracloroeteno & $\mu \mathrm{g} / \mathrm{L}$ & - & 40 & $<2$ \\
\hline Triclorobenzenos & $\mu \mathrm{g} / \mathrm{L}$ & - & 20 & $<5$ \\
\hline Trihalo Benzenos & $\mu \mathrm{g} / \mathrm{L}$ & - & 20 & $<5$ \\
\hline Tricloroeteno & $\mu \mathrm{g} / \mathrm{L}$ & - & 70 & $<5$ \\
\hline Monoclorobenze-no & $\mathrm{mg} / \mathrm{L}$ & - & 0,12 & $<0,05$ \\
\hline Etilbenzeno & $\mathrm{mg} / \mathrm{L}$ & - & 0,2 & $<0,05$ \\
\hline Tolueno & $\mathrm{mg} / \mathrm{L}$ & - & 0,17 & $<0,05$ \\
\hline Xileno & $\mathrm{mg} / \mathrm{L}$ & - & 0,3 & $<0,05$ \\
\hline \multicolumn{5}{|l|}{ Desinfetantes } \\
\hline Monocloramina & $\mathrm{mg} / \mathrm{L}$ & 0,06 & 3 & $<0,06$ \\
\hline Trihalometano Total & $\mathrm{mg} / \mathrm{L}$ & - & 0,1 & $<0,05$ \\
\hline \multicolumn{5}{|l|}{ Cátions principais } \\
\hline Cálcio & $\mathrm{mg} / \mathrm{L}$ & - & - & 3,17 \\
\hline Potássio & $\mathrm{mg} / \mathrm{L}$ & - & - & 0,47 \\
\hline Magnésio & $\mathrm{mg} / \mathrm{L}$ & - & - & 1,55 \\
\hline Sódio & $\mathrm{mg} / \mathrm{L}$ & 0,05 & 200 & 1,25 \\
\hline \multicolumn{5}{|l|}{ Ânions principais } \\
\hline Alcalinidade em bicarbonatos & $\mathrm{mg} / \mathrm{L} \mathrm{CaCO} 3$ & - & - & 18 \\
\hline Cloreto & $\mathrm{mg} / \mathrm{L}$ & 1 & 250 & 2,72 \\
\hline Nitrato & $\mathrm{mg} / \mathrm{L}$ & 0,05 & 10 & 0,6 \\
\hline Sulfato & $\mathrm{mg} / \mathrm{L}$ & 2 & 250 & 26,58 \\
\hline
\end{tabular}


Quanto ao tipo de água subterrânea, as águas do aqüífero freático são classificadas como sendo sulfatadas cálcicas, conforme é mostrado no diagrama triangular de Piper (1944) da Figura 10.

Na Figura 11, é mostrada a distribuição relativa dos cátions e ânions principais.

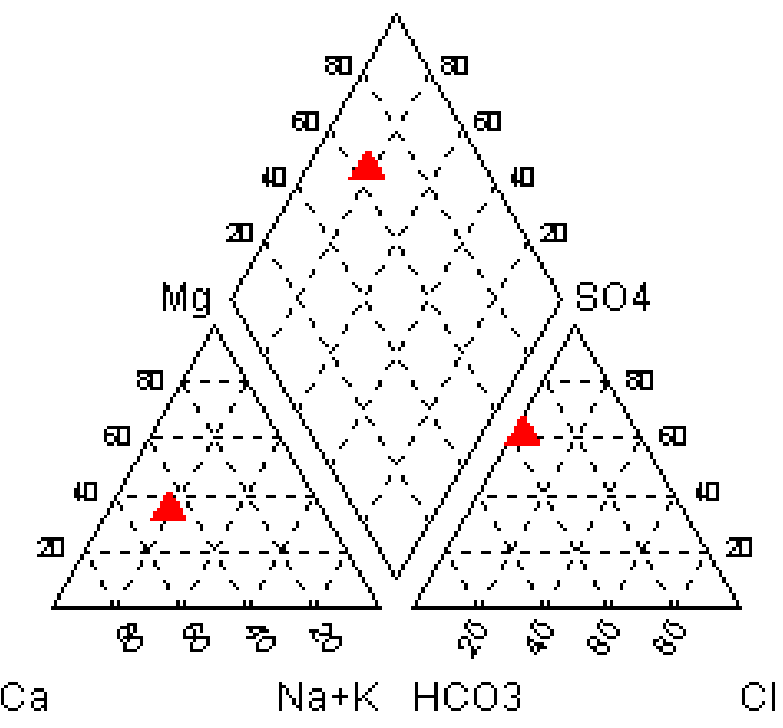

Figura 10. Ponto representativo das águas do Piezômetro 4, no diagrama triangular de Piper.

A quantidade de sólidos totais dissolvidos (apenas $7 \mathrm{mg} / \mathrm{L}$ ) com predomínio dos cátions cálcio e magnésio e dos ânions sulfato e bicarbonato mostra que no aqüífero freático, os elementos dissolvidos em estado iônico, perfazem uma pequena quantidade.
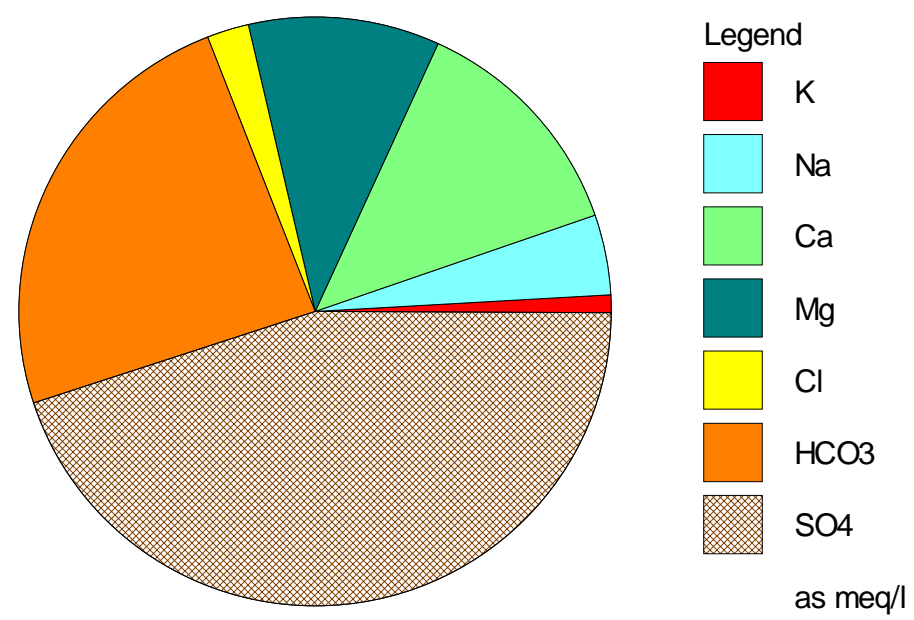

Figura 11. Gráfico da distribuição relativa dos principais elementos que se encontram dissolvidos nas águas subterrâneas do aqüífero freático. 


\section{CONCLUSÕES}

$\mathrm{Na}$ área da bacia do rio Una, onde está localizado o Departamento de Ciências Agrárias da UNITAU, ocorrem latossolos vermelho-amarelos (conhecidos como variação Una), constituídos principalmente, pelos argilo-minerais caulinita e illita, e grãos de quartzo. A espessura desse solo, coluvionar, no local, desenvolvido sobre sedimentos terciários da Formação Tremembé, varia entre 10 e $20 \mathrm{~m}$, com as menores espessuras no talvegue e planícies de inundação do ribeirão Itaim e rio Una e, as maiores, nos topos das colinas tabulares.

Ensaios geotécnicos realizados em amostras coletadas na área do Departamento de Ciências Agrárias, em laboratório de solos do Departamento de Ciências Agrárias da UNITAU e no laboratório de solos da Alphageos e de sedimentologia do Instituto Geológico do Estado de São Paulo, para conhecimento dos Índices Físicos, mostram que esse solo é bastante poroso, em torno de $53 \%$, e com umidade natural de aproximadamente $30 \%$. Com esses parâmetros, a cada $0,375 \mathrm{~m}$ de infiltração de água no solo, haverá um metro de correspondente elevação da coluna de água do aqüífero freático. Neste trabalho, essa capacidade de armazenar água por $\mathrm{m}^{3}$ de solo, foi definida como sendo o Armazenamento Unitário do Solo.

Medidas históricas do nível d'água do aqüífero freático, realizadas em 6 piezômetros construídos aos pares (para aferição das medidas de nível d'água e, para que um possa ser usado para injeção de água e outro para as medidas de subida de nível, possibilitando o cálculo da Condutividade Hidráulica do solo), sendo 2 localizados em uma encosta e 4 na base de uma colina tabular, mostraram que as variações da altura da água (medidas reais) apresentam uma correspondente variação da água disponível para infiltrar, obtida pelo balanço hídrico realizado no mesmo período (dados obtidos no Posto Meteorológico da Estação UNITAU/INMET n ${ }^{\circ}$ 83784, do Departamento de Ciências Agrárias da UNITAU), e multiplicada pelo correspondente Armazenamento Unitário do Solo.

Os métodos utilizados e as medidas obtidas permitiram calcular a descarga de água do aqǘ́fero freático nas fontes, sendo na média de $12,53 \mathrm{~mm} /$ dia no período chuvoso (entre $8 \mathrm{de}$ fevereiro e 3 de março de 2006), e na média de 1,85 $\mathrm{mm}$ nos outros períodos do ano. Em relação aos piezômetros $1,2,3$, e 4 , o nível d'água não desceu abaixo de $-3,46 \mathrm{~m}$. Considerando esse datum, quando o aqüífero freático possui carga hidráulica acima de $0,6 \mathrm{~m}$, haverá descarga de $12,53 \mathrm{~mm} /$ dia e, quando a carga hidráulica for inferior a $0,6 \mathrm{~m}$, a descarga nas fontes será de $1,85 \mathrm{~mm} /$ dia.

O piezômetro 1 (com profundidade de $4 \mathrm{~m}$ ) está situado a montante do piezômetro 4 (com profundidade de 4,5 m), a apenas $6 \mathrm{~m}$ de distância, mas mostra diferenças significativas. Ambos possuíam o nível d'água, na época da coleta, de 3,5 $\mathrm{m}$ de profundidade. A existência de coliformes fecais no piezômetro 4, situado a jusante, denota bactérias oriundas de infiltração de águas provenientes de fossas sépticas ou contaminadas por esgoto doméstico, como as provenientes do ribeirão Itaim. Baixos teores de bário (respectivamente, 0,32 e 0,11 $\mathrm{mg} / \mathrm{L}$ ) e chumbo (respectivamente, 0,08 e $0,05 \mathrm{mg} / \mathrm{L}$ ) mostram a presença, em pequenas quantidades, de elementos nocivos à saúde, de origem natural. $\mathrm{O} \mathrm{pH}$ das amostras é ácido $(4,9)$ e indica águas de circulação rápida, o causador deste $\mathrm{pH}$ baixo é o gás carbônico contido na atmosfera e dissolvido nas águas das chuvas infiltradas, onde se dissocia em bicarbonato e ácido carbônico. O pequeno tempo de residência dessas águas do aqüífero freático não permite a reação com os carbonatos sedimentares que poderiam aumentar o $\mathrm{pH}$ e a alcalinidade que, no caso, é baixa. 


\section{AGRADECIMENTOS}

Somente foi possível realizar este trabalho graças aos recursos provenientes da Fundação de Amparo à Pesquisa do Estado de São Paulo (FAPESP), por meio do Projeto $\mathrm{n}^{0}$ 2003/07183-1, da colaboração efetiva do Departamento de Ciências Agrárias da UNITAU, por seus professores Paulo Fortes Neto, Getulio Teixeira Batista e Marcelo dos Santos Targa, e dos ex-alunos do Programa de Pós-Graduação em Ciências Ambientais da UNITAU, Dr. Adilson Peloggia, M.Sc. José Luiz Gonçalves, M.Sc. Mário Pero Tinoco e M.Sc. Jorge Luiz Monteiro. Para os trabalhos de campo, foi importante o apoio material como também dos funcionários do Instituto Geológico do Estado de São Paulo, principalmente dos sondadores, Santo Duarte Camargo e Aparecido Magalhães, e dos técnicos do laboratório de análises de sedimentologias, Ivete Costa da Silva e José Alves de Andrade. Agradecemos também, à empresa Alphageos pela realização dos ensaios geotécnicos.

\section{REFERENCIAS}

ALMEIDA, F. F. M. The system of continental rifts bordering the Santos Basin, Brazil. Rio de Janeiro: Anais da Academia Brasileira de Ciências, 1976. p. 15-26. Suplemento 48 .

BUENO, B. S.; VILAR, O. M. Mecânica dos solos. São Carlos: Escola de Engenharia de São Carlos, Departamento de Geotecnia, 1984. 131p. Publicação 004/85.

CARNEIRO, C. D. R.; HASUI, Y.; GIANCURSI, F. D. Estrutura da Bacia de Taubaté na região de São José dos Campos. In: CONGRESSO BRASILEIRO DE GEOLOGIA, 29., 1976, Ouro Preto. Anais... Ouro Preto: SBG, 1976. p. 247-256. vol. 4.

COLTRINARI, L. Geomorfologia e dinâmica quaternária no sudeste do Brasil. Revista do Departamento de Geografia da FFLCH/USP, São Paulo, n. 6, p. 7-16, 1992.

D’ANGiOlella, G. L. B.; VASCONCELlOS, V. L. D. Cálculo do balanço hídrico climatológico com diferentes métodos para estimativa da evapotranspiração potencial, em planilhas Excel ${ }^{\mathrm{TM}}$. In: CONGRESSO BRASILEIRO DE METEOROLOGIA, 12. 2002, Foz do Iguaçu. Anais... Brasília: SBMET, 2002. 1 CD-ROM.

FETTER, C. W. Applied hidrogeology. 2. ed. Nova York, Macmillan Publ., 1988. 592 p.

FRANCO FILHO, F. W. B.; SOUZA, J. C. S. Explotação de água subterrânea em São José dos Campos - efeitos observados ao longo do tempo. In: CONGRESSO BRASILEIRO DE ÁGUAS SUBTERRÂNEAS, 8., 1994, Recife. Anais... Recife: ABAS, 1994, p. 113-123. vol. 1.

GREENBERG, A. E.; CLESCERI, L. S.; EATON, A. D. Standard methods for the examination of water and wastewater. Washington: American Public Health Association, 1998. 400 p.

HASUI, Y.; GIMENEZ, A. F.; MELO, M. S. Sobre as bacias tafrogênicas do sudeste brasileiro. In: CONGRESSO BRASILEIRO GEOLOGIA, 30., 1978, Recife. Anais... Recife: SBG, 1978. p. 382-392. vol. 1. 
HASUI, Y.; PONÇANO, E. W. Organização estrutural e evolução da bacia de Taubaté. In: CONGRESSO BRASILEIRO GEOLOGIA, 30., 1978, Recife. Anais... Recife: SBG, 1978. p. 368-381. vol. 1.

MELO, M. S.; CAETANO, S. L. V.; COIMBRA, A. M. Tectônica e sedimentação nas áreas das bacias de São Paulo e Taubaté. In: CONGRESSO BRASILEIRO DE GEOLOGIA, 34., 1986, Goiânia. Anais... Goiânia: SBG, 1986. p. 321-336. vol. 1.

NOGUEIRA, J. B. Mecânica dos solos: ensaios de laboratório. São Carlos: EESC-USP, 1995. 248p.

OLIVEIRA, J. B.; CAMARGO, M. N.; ROSSI, M., CALDERANO FILHO, B. Mapa pedológico do Estado de São Paulo: legenda expandida. Campinas: Instituto Agronômico de Campinas, Embrapa Solos, 1999. 64 p. 1 mapa.

PEREIRA, A. R.; VILLA NOVA, N. A.; SEDIYAMA G. C. Evapo(transpi)ração. Piracicaba: FEALQ, 1997. 183p.

PIPER, A. M. A graphic procedure in the geochemical interpretation of water analyses. American Geophysical Union Transaction, Washington, v. 25, p. 914-923, 1944.

RICCOMINI, C. O Rift Continental do Sudeste do Brasil. 1989. 256f. Tese (Doutorado em Geociências) - Instituto de Geociências, Universidade de São Paulo, São Paulo, 1989.

RUSHTON, K. R.; WARD, C. The estimation of ground water recharge. Journal of Hidrology, Washington, v. 40, p.49-65, 1979.

SANTORO, J. Fenômenos erosivos acelerados na região de São Pedro - S.P.: estudo da fenomenologia com ênfase geotécnica. 1991. 140f. Dissertação (Mestrado em Geotecnia e Meio Ambiente) - Instituto de Geociências e Ciências Exatas de Rio Claro, Universidade Estadual Paulista, Rio Claro, 1991.

SÃO PAULO (Estado). Secretaria de Recursos Hídricos, Saneamento e Obras. Departamento de Águas e Energia Elétrica. Estudo de águas subterrâneas: região administrativa 3 São José dos Campos e faixa litorânea. São Paulo: DAEE, 1977a. 112 p. vol. 1.

SÃO PAULO (Estado). Secretaria de Recursos Hídricos, Saneamento e Obras. Departamento de Águas e Energia Elétrica. Estudo de águas subterrâneas: região administrativa 3 São José dos Campos e faixa litorânea. São Paulo: DAEE, 1977b. 160p. vol. 5. (mapas e tabelas).

STANCATI, G.; NOGUEIRA, J. B.; VILAR, O. M. Ensaios de laboratório em mecânica dos solos. São Carlos: EESC, 1981. 208p. il. Publicação 004/87.

VERDADE, F. C.; HUNGRIA, L. S. Estudo genético da bacia orgânica do Vale do Paraíba. Revista Bragantia, Campinas, v. 25, n. 16, p. 189-202, 1966. 


\section{Avaliação da precipitação efetiva de um fragmento de Mata Atlântica em diferentes estágios de regeneração no município de Viçosa, MG}

(doi:10.4136/ambi-agua.21)

\section{Rafael Figueiredo Alves'; Herly Carlos Teixeira Dias'; José Carlos de Oliveira Júnior²; Franklin Nicolai Mota Garcia ${ }^{1}$}

${ }^{1}$ Universidade Federal de Viçosa

${ }^{2}$ Plantar SA

E-mail: rafaelufv@hotmail.com; herly@ufv.br; jose-oliveira@plantar.com.br; fnmgarcia@yahoo.com.br

\section{RESUMO}

O presente trabalho teve por objetivo avaliar a precipitação efetiva de um fragmento do bioma Mata Atlântica composto por floresta estacional semidecidual em diferentes estágios de regeneração no município de Viçosa, MG, no período de novembro de 2005 a outubro de 2006. Foram demarcadas quatro parcelas experimentais, sendo três em uma área de estágio de regeneração inicial e uma em estágio de regeneração avançado. Durante o estudo foram efetuadas 24 coletas de precipitação a céu aberto, precipitação interna e escoamento pelo tronco, constituídas de um ou mais eventos de chuva. A precipitação média total do período estudado foi de $997 \mathrm{~mm}$. A precipitação efetiva na área em que o estágio de regeneração se encontra mais avançado, com área basal igual a $3,28 \mathrm{~m}^{2}$, foi de $813,90 \mathrm{~mm}$ o que correspondeu a $81,63 \%$ da precipitação a céu aberto. Na área em que o estágio de regeneração se encontra inicial, com área basal igual a $1,22 \mathrm{~m}^{2}$, a precipitação efetiva foi de $792,46 \mathrm{~mm}$ o que correspondeu a $79,43 \%$ da precipitação a céu aberto. A interceptação pelas copas resultou em $18,37 \%$ e $20,57 \%$ para as áreas de regeneração avançada e inicial, respectivamente. Os resultados analisados estatisticamente pelos testes $t$ e teste $f$, não apresentaram diferença significativa.ao nível de $5 \%$ de probabilidade.

Palavras-chave: Precipitação efetiva; mata atlântica; hidrologia florestal.

\section{Evaluation of net precipitation in a fragment of Mata Atlântica in different regeneration stages in the municipal district of Viçosa, MG.}

\section{ABSTRACT}

The goal of this present work was to evaluate the net precipitation in a fragment of the Mata Atlântica biome compound of semideciduous seasonal forest in different regeneration stages in Viçosa, MG, from November of 2005 to October of 2006. It was demarcated four experimental parcels, which three of them were allocated into an initial regeneration area and one into an advanced regeneration area. Gross precipitation, net precipitation and steamflow were measured in 24 storm events, constituted of one or more storm events. The mean precipitation during the studied period was $997 \mathrm{~mm}$. The net precipitation on higher advanced regeneration area that has a basal area of $3.28 \mathrm{~m}^{2}$, was $813.90 \mathrm{~mm}$ which corresponded to $81.63 \%$ of gross precipitation. The initial regeneration area, that has a basal area of $1.22 \mathrm{~m}^{2}$, was $792.46 \mathrm{~mm}$ which corresponded to $79.43 \%$ of gross precipitation. The canopy interception was $18.37 \%$ e $20.57 \%$, to advanced regeneration area and initial regeneration areas, respectively. The results were statistically evaluated by t-test and f-test, and showed no significant difference on $5 \%$ of probability.

Keywords: Net precipitation; mata atlântica; forest hydrology. 


\section{INTRODUÇÃO}

Em sua origem, a Mata Atlântica ocupava 15\% do território brasileiro e era distribuída por 17 estados desde o Rio Grande do Norte até o Rio Grande do Sul. Ela era a segunda maior floresta tropical da América do Sul, atrás somente da Floresta Amazônica. Depois de cinco séculos de devastação, porém, restam, atualmente, apenas $7,3 \%$ da área original desse bioma conhecido como uma das florestas de maior diversidade do mundo. O processo de devastação continua colocando em risco várias espécies que só são encontradas neste local. Em Minas Gerais a floresta secundária substituiu, praticamente, todas as florestas primárias existentes, restando apenas pequenas manchas remanescentes, que correspondem a menos de $2 \%$ do território mineiro (Dalben, 2006).

Segundo Castro et al. (1983) a cobertura florestal atua no ciclo hidrológico provocando um retardamento e redução da movimentação da água em direção aos cursos de água, por meio de processos de interceptação, infiltração, absorção, transpiração e percolação.

A precipitação pluvial é definida em hidrologia como toda água proveniente da atmosfera que atinge a superfície terrestre. Devido a sua capacidade de produzir escoamento superficial, a chuva é o tipo de precipitação mais importante para hidrologia florestal (Bertoni; Tucci, 2001).

Em florestas naturais ou plantadas, a quantidade de água de chuva que atinge a serrapilheira é denominada precipitação efetiva que é dada pela precipitação interna e escoamento pelo tronco (Lima, 1975).

A precipitação interna é a chuva que atinge o piso florestal, incluindo gotas que passam diretamente pelas aberturas existentes entre as copas e gotas que respingam do dossel. A fração da chuva que é retida temporariamente pelas copas juntamente com aquela que atinge diretamente os troncos, e que posteriormente escoam pelo tronco das árvores, chegando ao solo, é denominado escoamento pelo tronco. A soma da precipitação interna e escoamento pelo tronco são responsáveis pela água do solo (Arcova et al., 2003).

A precipitação efetiva pode variar em função de alguns fatores tais como: área basal, tipo de espécie, diâmetro das árvores, quantidade de espécies, densidade das árvores, além da freqüência e intensidade de chuvas. De modo que a área basal dos indivíduos pode levar a resultados mais consistentes quando comparados a precipitação efetiva da área.

Diante disto, este trabalho teve por objetivo avaliar a precipitação efetiva de um fragmento do bioma Mata Atlântica composto por formação florestal estacional semidecidual em diferentes estágios de regeneração no município de Viçosa, $\mathrm{MG}$, no período de novembro de 2005 a outubro de 2006.

\section{MATERIAIS E MÉTODOS}

\subsection{Características gerais da área de estudo}

A Estação de treinamento, pesquisa e educação Ambiental Mata do Paraíso (Figural e Figura 2), pertencente à Universidade Federal de Viçosa, localiza-se no município de Viçosa que por sua vez esta localizado ao norte da Zona da Mata do Estado de Minas Gerais, a 229 $\mathrm{Km}$ da capital Belo Horizonte. Situado entre as latitudes de $20^{\circ} 41^{\prime} 20^{\prime \prime} \mathrm{S}$ a $20^{\circ} 49^{\prime} 35^{\prime}$ 'S e entre as longitudes de 42 49' 36' 'WGr a 42 54' 27' 'WGr (Oliveira Jr., 2006). A uma altitude média de 650 metros, o município abrange uma área de $300,15 \mathrm{Km}^{2}$. A Mata do paraíso situase a aproximadamente $6 \mathrm{Km}$ da Universidade Federal de Viçosa e possui uma área de 194 hectares. 


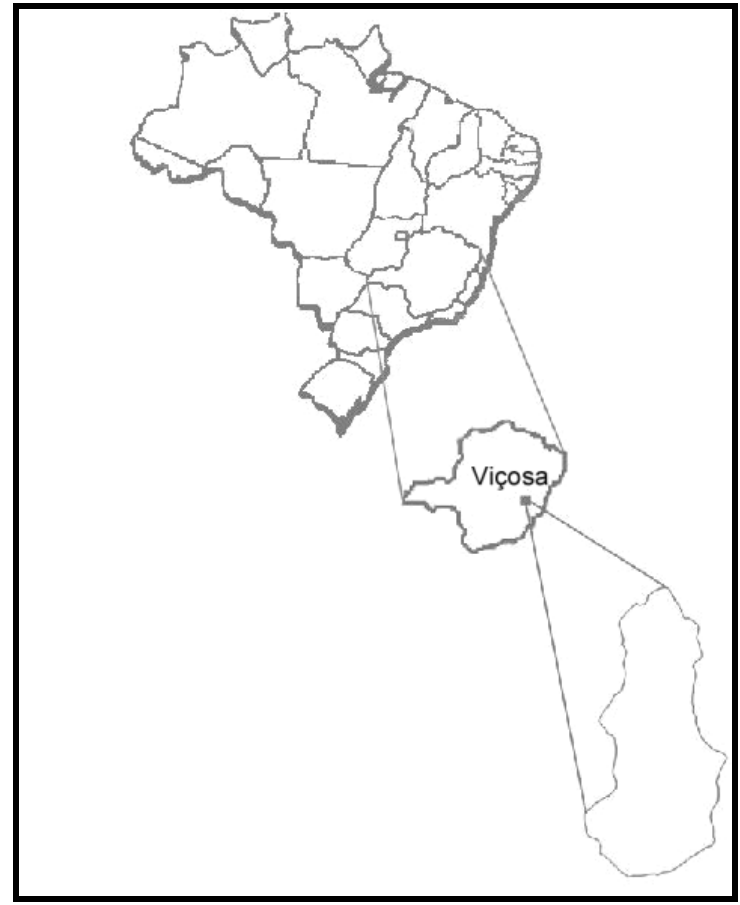

Figura 1. Localização geográfica da Estação de treinamento, pesquisa e educação Ambiental, Mata do Paraíso, Viçosa, MG.

Fonte: Oliveira Jr. (2006).

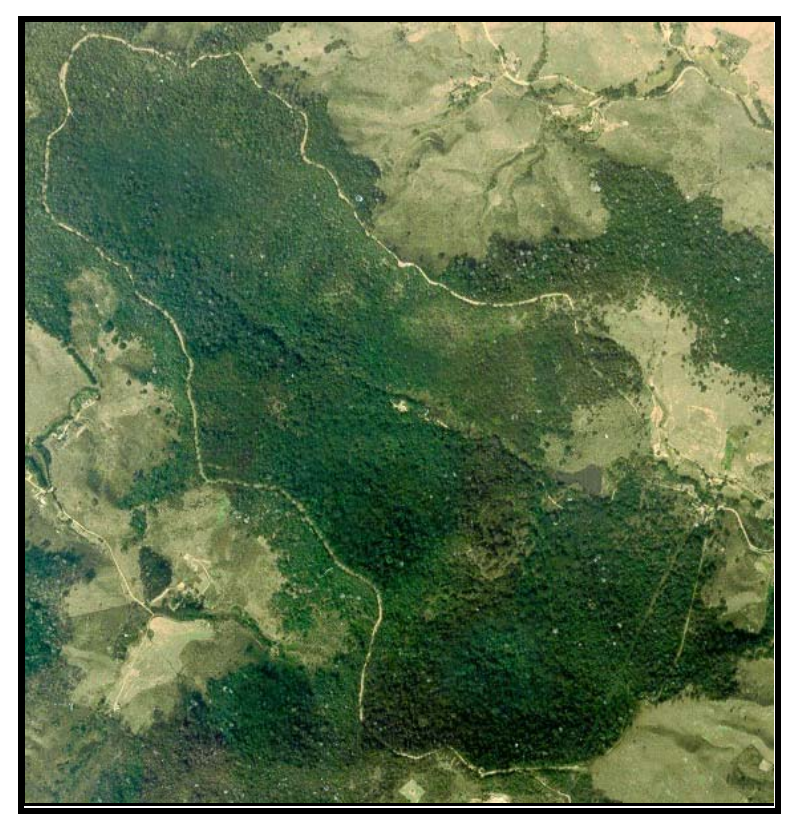

Figura 2. Localização geográfica da Estação de treinamento, pesquisa e educação Ambiental, Mata do Paraíso, Viçosa, MG.

Fonte: Oliveira Jr. (2006).

De acordo com a classificação de Köppen, o tipo climático de Viçosa é Cwa, descrito como:

"C" - clima temperado quente: sendo que a temperatura média do mês mais frio entre $18^{\circ} \mathrm{e}-3 \mathrm{C}$, mesotérmico. 
“w” - a época mais seca coincide com o inverno no hemisfério correspondente, comportando pelo menos um mês com precipitação, em média inferior a $60 \mathrm{~mm}$. A razão entre as precipitações mensais mínimas e máximas tem que ser inferior a 1/10.

"a" - a temperatura média do mês mais quente é superior a $22^{\circ} \mathrm{C}$.

A média das temperaturas máximas é de $26,1^{\circ} \mathrm{C}$ e a das mínimas é de $14,0{ }^{\circ} \mathrm{C}$, a umidade relativa média é elevada em todos os meses, com uma média anual de $80 \%$, a precipitação média observada é de $1220,0 \mathrm{~mm}$ por ano.

Em grandes áreas da Zona da Mata do Estado de Minas Gerais, incluindo o município de Viçosa e a Mata do Paraíso, a paisagem se divide em encostas, terraços, leito maior e leito menor. O leito menor é compreendido pelos cursos d'água. O leito maior refere-se às áreas da paisagem que são inundadas periodicamente, apresentando solos jovens devido a constante deposição de materiais feita durante o período de inundação. Os terraços são áreas que não são inundadas, com grande concentração de atividades humanas, urbanas e agrícolas, possuindo solos um pouco mais velhos que os solos do leito maior. As encostas são representadas por áreas de relevo acidentado, apresentando solos mais velhos da paisagem (Resende, 1971).

Os solos da Mata do Paraíso são classificados como Latossolo Varmelho-Amarelo distrófico nas áreas com perfis convexos, Câmbicos nos topos das elevações em função da existência de horizonte B de pequena espessura, Argilossolos nas áreas de perfis côncavos e nos terraços e Hidromórficos aluviais no leito maior.

A bacia hidrográfica, onde se encontra a Mata do Paraíso, possui uma forma retangular, onde o maior comprimento é paralelo ao curso d'água principal (Castro, 1980).

\subsection{Precipitação a céu aberto (P)}

A média da precipitação a céu aberto foi obtida a partir de medições realizadas com dois pluviômetros, sendo um deles simples de PVC com área de captação igual a $167 \mathrm{~cm}^{2}$ e o outro, um pluviômetro digital. Esses dois foram instalados acima do dossel da floresta.

Para o cálculo da precipitação atmosférica no pluviômetro de PVC, utilizou - se a equação:

$$
P=\left(\frac{V}{A}\right) \times 10
$$

em que P é a precipitação atmosférica $(\mathrm{mm}), \mathrm{V}$ é o volume do pluviômetro $(\mathrm{ml})$ e A é a área de captação do pluviômetro $\left(167 \mathrm{~cm}^{2}\right)$.

\subsection{Precipitação interna (Pi)}

Para quantificar a precipitação interna foram demarcadas três parcelas de $20 \mathrm{~m}$ x $20 \mathrm{~m}$ sucessivas, espaçadas entre si por $10 \mathrm{~m}$, na área de regeneração inicial, e uma parcela de $20 \mathrm{~m}$ por $20 \mathrm{~m}$ na área de regeneração mais avançada. Em cada parcela foram instalados 25 coletores com área de captação igual a $83,6 \mathrm{~cm}^{2}$.

Para o cálculo da precipitação interna em cada parcela utilizou-se a equação:

$$
P i=\frac{\left(\sum\left(\frac{V}{A}\right) \times 10\right)}{25}
$$

em que Pi é a precipitação interna $(\mathrm{mm}), \mathrm{V}$ é o volume de cada pluviômetro (ml) e A é a área de captação de cada pluviômetro $\left(\mathrm{cm}^{2}\right)$. 


\subsection{Escoamento pelo tronco (Et)}

Para quantificar o escoamento pelo tronco foram demarcadas 3 sub-parcelas de $10 \mathrm{~m} \mathrm{x}$ $10 \mathrm{~m}$ das parcelas da precipitação interna, na área de regeneração inicial e uma na área de regeneração avançada Em cada sub-parcela foram adaptados coletores à base de poliuretano nos troncos das árvores com CAP $\geq 15 \mathrm{~cm}$.

Para o cálculo do escoamento pelo tronco utilizou-se a seguinte equação:

$$
E t=\sum\left(\frac{V}{A S}\right)
$$

em que Et é o escoamento pelo tronco (mm), V é o volume de cada coletor (L) e AS é a área da sub-parcela.

\subsection{Precipitação efetiva (Pe)}

A precipitação efetiva foi calculada pela soma da precipitação interna e do escoamento pelo tronco, de acordo com a seguinte equação:

$$
P e=P i+E t
$$

em que Pe é a precipitação efetiva $(\mathrm{mm})$, Pi é a precipitação interna $(\mathrm{mm})$ e Et é o escoamento pelo tronco $(\mathrm{mm})$.

\subsection{Interceptação (Ic)}

A quantidade de água interceptada pela copa será obtida pela diferença entre a precipitação em aberto e a precipitação efetiva, de acordo com a equação abaixo:

$$
\text { Ic }=P-P e
$$

em que Ic é a perda por interceptação $(\mathrm{mm})$, P é a precipitação a céu aberto(mm) e Pe é a precipitação efetiva $(\mathrm{mm})$.

\section{7. Área Basal}

O diâmetro das árvores foi obtido a partir da medida do CAP (circunferência a altura do peito, $1,30 \mathrm{~cm}$ ) de todas as árvores com CAP $\geq 15 \mathrm{~cm}$, dentro de cada parcela de $20 \mathrm{~m} \times 20 \mathrm{~m}$. Primeiramente transforma-se o CAP em DAP pela seguinte equação:

$$
D A P=\frac{C A P}{\prod}
$$

em que DAP é o diâmetro a altura do peito $(1,30 \mathrm{~cm})$, e $\prod(3,1416)$

Para a totalização da área basal de cada parcela utilizou-se a seguinte equação:

$$
A b=\frac{\prod \times\left(D A P^{2}\right)}{40000}
$$

em que $\mathrm{Ab}$ é a área basal $\left(\mathrm{m}^{2}\right), \Pi(3,1416)$ e DAP é o diâmetro a altura do peito $(1,30$ $\mathrm{cm})$.

\section{RESULTADOS E DISCUSSÃO}

\section{1. Área basal}

Nas áreas de regeneração avançada (RA) e regeneração inicial (RI) foram encontradas, respectivamente, as áreas basais de 3,28 e 1,22 $\mathrm{m}^{2}$. Isso vem a confirmar a diferença nestas duas áreas quanto ao estágio de regeneração (RA e RI). Observa-se que, na área de regeneração inicial a um maior número de árvores de menores diâmetros e uma maior densidade populacional, o que dificulta o deslocamento. Já na área de regeneração avançada, 
o número de árvores é reduzido, e o diâmetro das árvores é maior. Além disso, pode-se observar uma diferença das duas áreas quanto ao fechamento do dossel.

Feita a distribuição por classe diamétrica podemos observar na Figura 3, que são poucos os indivíduos representados pelo centro de classe $2,5 \mathrm{~cm}$, na área de regeneração mais avançada, isto seria um estoque de regeneração presente na área, a partir do centro de classe $52,5 \mathrm{~cm}$ só foram encontrados indivíduos na área de regeneração mais avançada, mostrando que esta área esta mesmo a frente quanto ao estágio de regeneração.

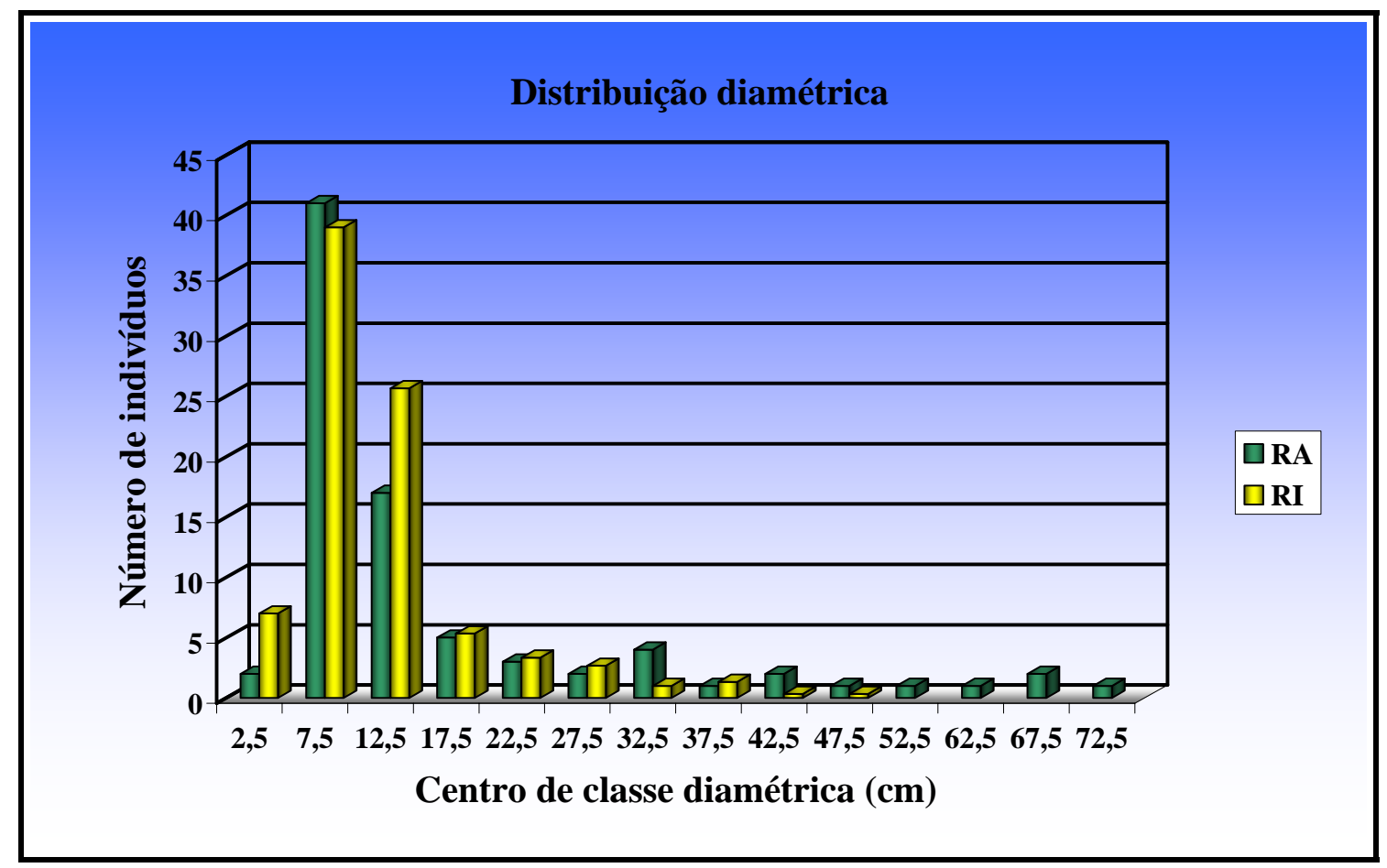

Figura 3. Distribuição por classe diamétrica na área de regeneração avançada (RA) e área de regeneração inicial (RI), Estação de treinamento, pesquisa e educação Ambiental, Mata do Paraíso, Viçosa, MG, novembro 2005 a outubro 2006.

\subsection{Precipitação efetiva}

A precipitação efetiva na área de regeneração mais avançada foi de $813,90 \mathrm{~mm}$ (Figura 4) o que correspondeu a 81,63\% (Figura 5) da precipitação total, já área em estágio de regeneração inicial a precipitação efetiva foi de 792,46 mm (Figura 4) o que correspondeu a $79,43 \%$ (Figura 5) da precipitação total para o período considerado. Os resultados foram analisados estatisticamente através dos testes $\mathrm{t}$ e $\mathrm{f}$ a $5 \%$ de probabilidade e não tiveram diferença significativa.

Oliveira Jr. (2006) realizando estudos na mesma área de regeneração inicial, encontrou valores de precipitação efetiva igual a $79,3 \%$ da precipitação em aberto, com valores de precipitação interna de $76,7 \%$ e o escoamento pelo tronco igual a $2,6 \%$, a perda por interceptação foi de $20,7 \%$. As diferenças nos resultados podem estar relacionados ao período hidrológico, estudado a intensidade das chuvas, a periodicidade na coleta de dados, entre outros.

Castro et al. (1983), citado por Oliveira Jr. (2006) realizando estudos na mesma mata, mas em locais diferentes encontraram precipitação efetiva igual a $87,6 \%$ da precipitação em aberto, com valores de precipitação interna e o escoamento pelo tronco igual a 87,4\% e, 0,2\% respectivamente, e perda por interceptação igual a 12,4\%. As diferenças encontradas entre as duas avaliações podem ser devido à metodologia, à própria condução do experimento ou 

efetiva de um fragmento de Mata Atlântica em diferentes estágios de regeneração no município de Viçosa, MG. Ambi-Agua, Taubaté, v. 2, n. 1, p. 83-93, 2007. (doi:10.4136/ambi-agua.21)

ainda à amostragem, no entanto os resultados sugerem também o efeito do fechamento e ingresso de espécies ao dossel nesses mais de 20 anos de diferenças entre os dois trabalhos.

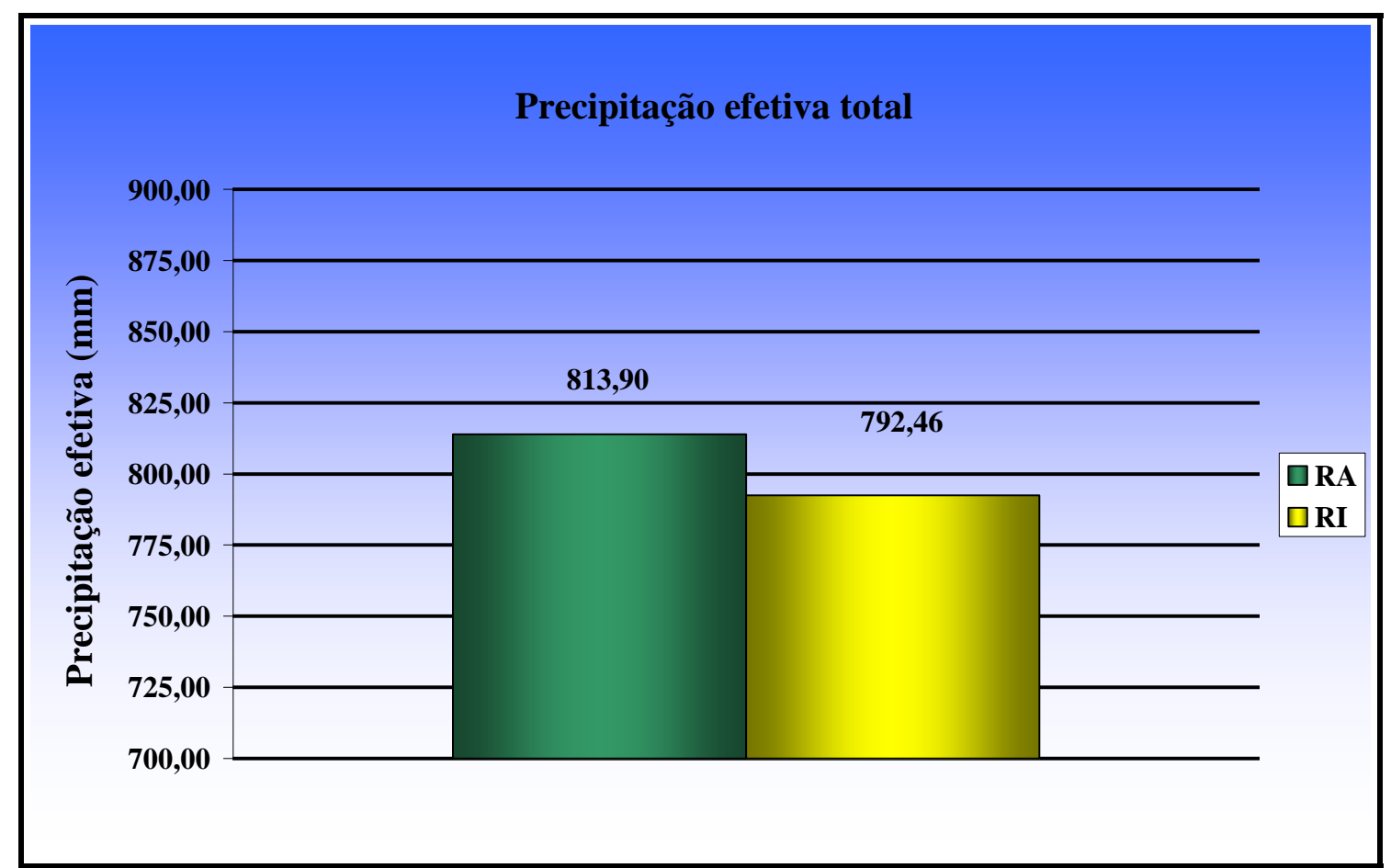

Figura 4. Precipitação efetiva total na área de regeneração avançada (RA) e área de regeneração inicial (RI), Estação de treinamento, pesquisa e educação Ambiental, Mata do Paraíso, Viçosa, MG, novembro 2005 a outubro 2006.

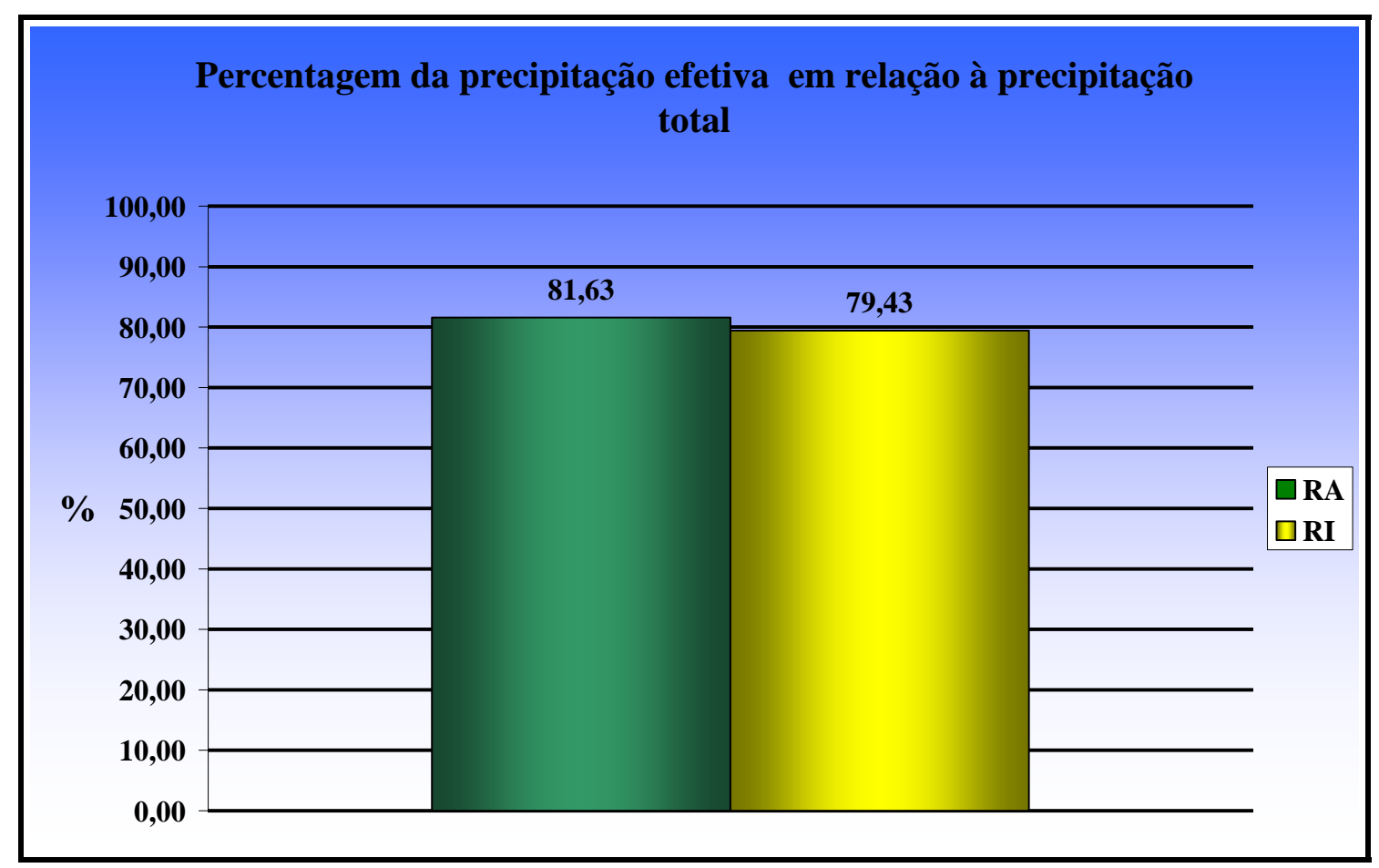

Figura 5. Precipitação efetiva em relação à precipitação total, em valores percentuais, na área de regeneração avançada (RA) e na área de regeneração inicial (RI), Estação de treinamento, pesquisa e educação Ambiental, Mata do Paraíso, Viçosa, MG, novembro 2005 a outubro 2006. 


\subsection{Precipitação interna}

$O$ valor da precipitação interna nas duas áreas em termos absolutos e em termos percentuais mostrados nas Figuras 6 e 7 respectivamente, na regeneração avançada este valor foi de $806,18 \mathrm{~mm}$ correspondendo a $80,86 \%$ da precipitação total, na área de regeneração inicial este valor foi de $788,69 \mathrm{~mm}$, o que correspondeu a $79,05 \%$ da precipitação total. Os resultados foram analisados estatisticamente através dos testes t e f a $5 \%$ de probabilidade e não tiveram diferença significativa.

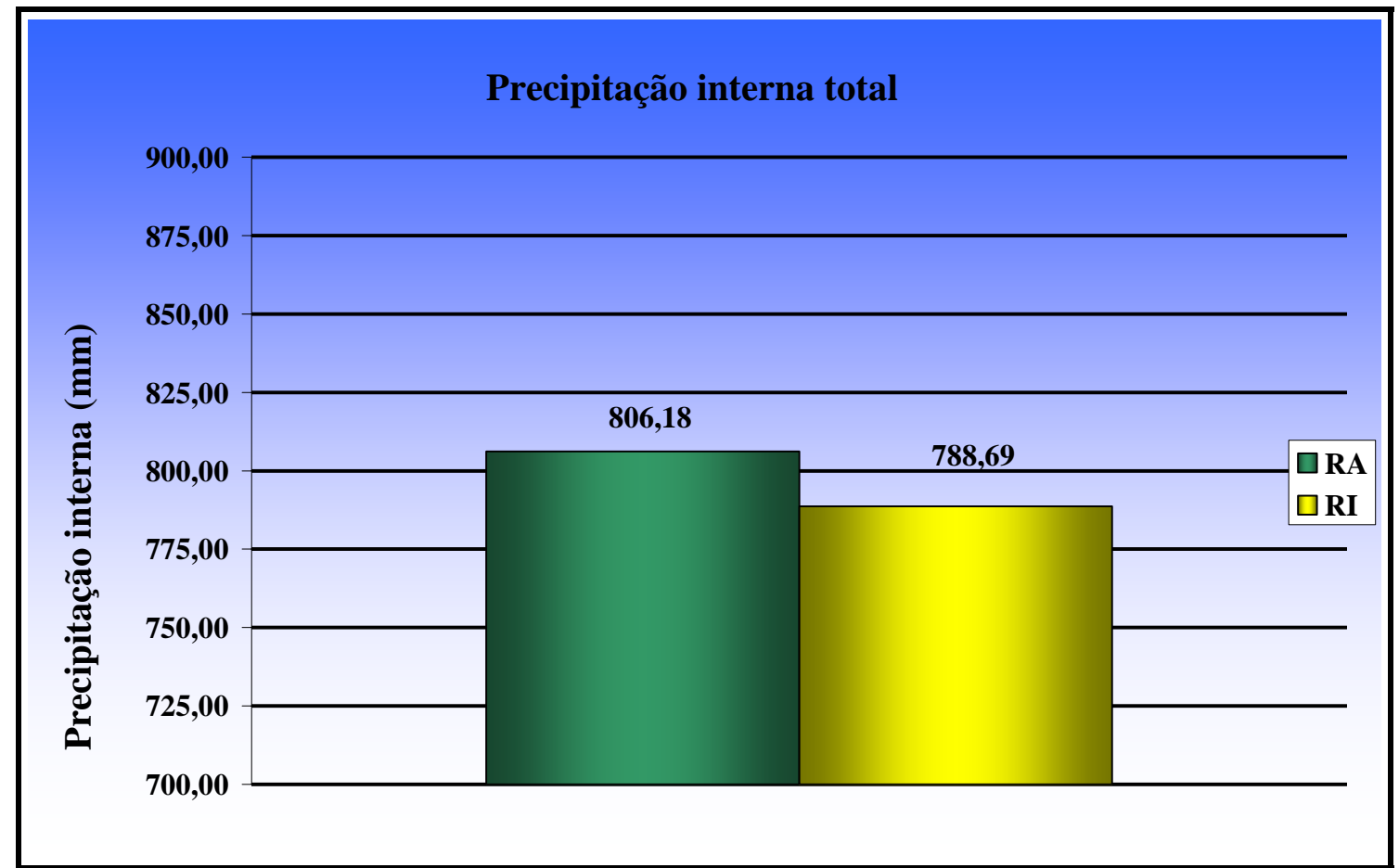

Figura 6. Precipitação interna total $(\mathrm{mm})$ nas áreas de regeneração avançada (RA), regeneração inicial (RI), Estação de treinamento, pesquisa e educação Ambiental, Mata do Paraíso, Viçosa, MG, novembro 2005 a outubro 2006.

Ferreira et al. (2005). Em floresta de terra firme submetida à extração seletiva de madeira na Amazônia Central encontrou valores de precipitação interna de 86,9 a 92,9\%, já na floresta intocada (controle) os valores foram de 74,2 a $87,1 \%$, essas alterações não foram significativas em termos estatísticos, mas influenciaram sensivelmente a quantidade de chuva nas áreas, levando a uma redução de chuva na área submetida ao manejo.

\subsection{Escoamento pelo tronco}

O Escoamento pelo tronco total encontrado para o período, foi de 7,72 $\mathrm{mm}$ na área de regeneração avançada (Figura 8), o que representa $0,77 \%$ da precipitação atmosférica total (Figura 9), já na área de regeneração inicial (RI) este valor foi de 3,77 mm (Figura 8), representando $0,38 \%$ da precipitação total atmosférica (Figura 9).

Os resultados foram analisados estatisticamente através dos testes $\mathrm{t}$ e $\mathrm{f}$ a $5 \%$ de probabilidade e não tiveram diferença significativa. Apesar do escoamento pelo tronco corresponder a um pequeno percentual da precipitação total, alguns autores consideram o volume escoado pelo tronco como um mecanismo de auto-abastecimento resultante da distribuição localizada e significante ao redor dos troncos, principalmente durante o período seco (Price, 1982; Huber; Oyarzún, 1983 citados por Lima; Leopoldo, 2000). O auto- 

efetiva de um fragmento de Mata Atlântica em diferentes estágios de regeneração no município de Viçosa, MG. Ambi-Agua, Taubaté, v. 2, n. 1, p. 83-93, 2007. (doi:10.4136/ambi-agua.21)

abastecimento exerce efeito sobre a qualidade da água que entra no solo (Johnson, 1990). O volume de água recebido nas proximidades dos troncos chegam a ser cinco vezes superior aquele recebido por áreas mais distantes (Navar; Bryan, 1990).

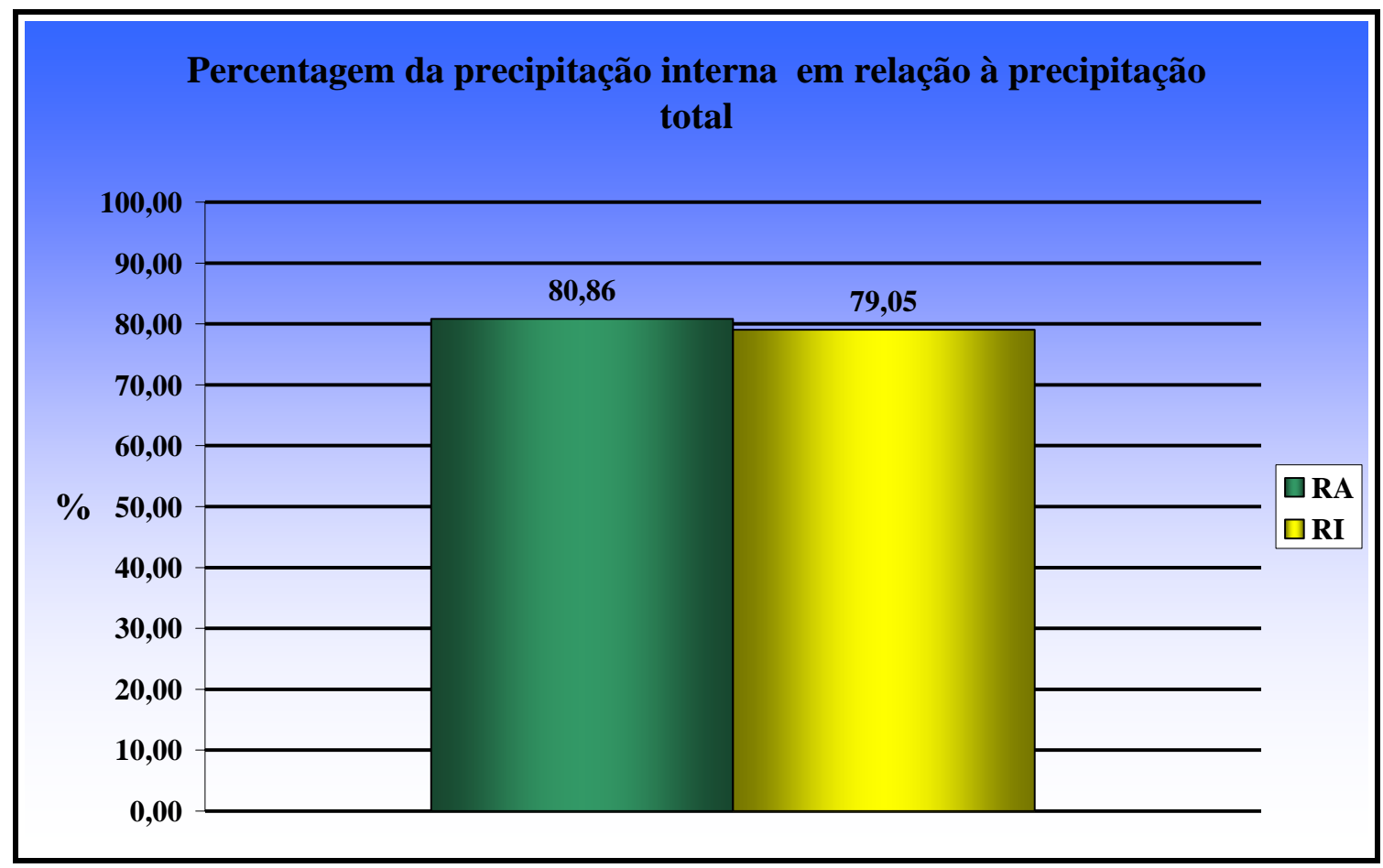

Figura 7. Precipitação interna em relação à precipitação total, nas áreas de regeneração avançada (RA), regeneração inicial (RI), Estação de treinamento, pesquisa e educação Ambiental, Mata do Paraíso, Viçosa, MG, novembro 2005 a outubro 2006.

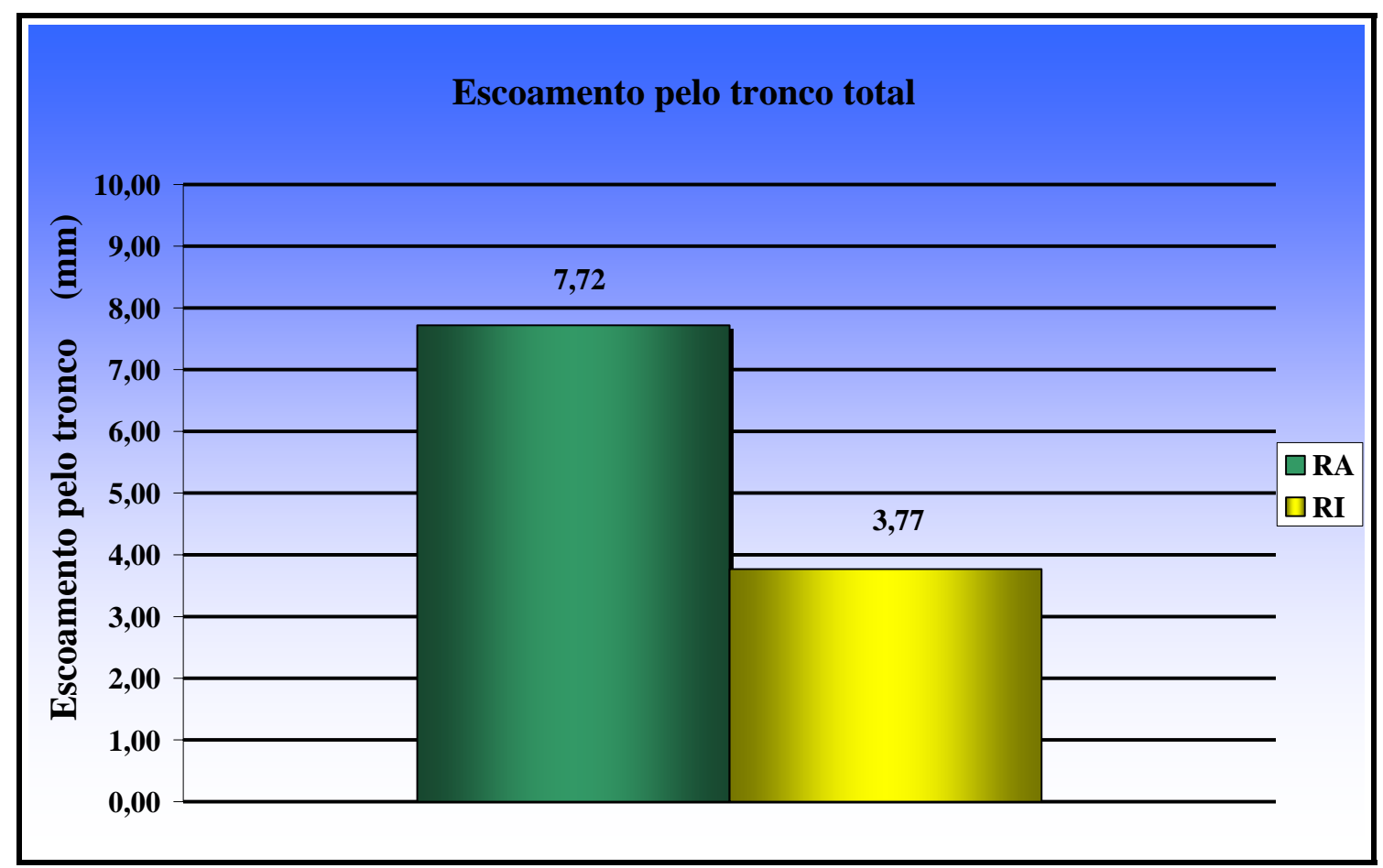

Figura 8. Escoamento pelo tronco total do período, em valores absolutos (mm), na área de regeneração avançada (RA) e na área de regeneração inicial (RI), Estação de treinamento, pesquisa e educação Ambiental, Mata do Paraíso, Viçosa, MG, novembro 2005 a outubro 2006. 


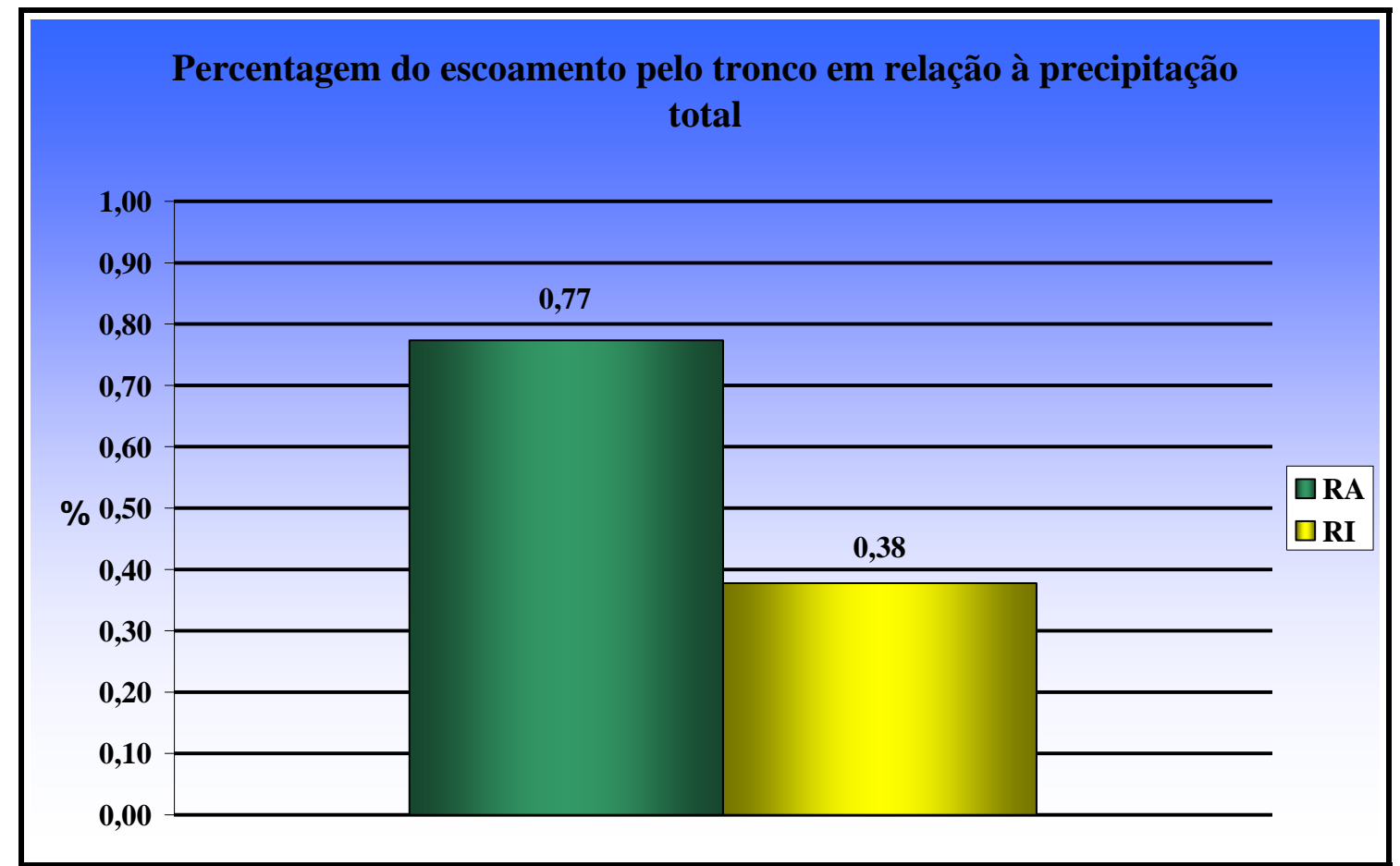

Figura 9. Percentagem do escoamento pelo tronco em relação à precipitação total nas áreas de regeneração avançada (RA) e regeneração inicial (RI), Estação de treinamento, pesquisa e educação Ambiental, Mata do Paraíso, Viçosa, MG, novembro 2005 a outubro 2006.

\section{CONCLUSÕES}

Com base nos resultados apresentados, podemos concluir que, estatisticamente não à diferença entre as áreas de regeneração inicial e avançada quanto à precipitação efetiva no período estudado. Além disso, a variável que mais contribui para a precipitação efetiva é a precipitação interna, ou seja, a água que passa entre o dossel da floresta ou que respinga da copa das árvores. Apesar da pequena contribuição do escoamento pelo tronco, este é de grande importância para a floresta como um todo. Foi comprovada a diferença nos estágios de regeneração pela área basal e distribuição diamétrica encontrada em cada área.

\section{REFERÊNCIAS}

ARCOVA, F. C. S.; CICCO, V.; ROCHA, P. A. B. Precipitação efetiva e interceptação das chuvas por floresta de mata atlântica em uma microbacia experimental em Cunha - SP. Revista Árvore, Viçosa, v. 27, n. 2, p. 257-262, 2003.

BERTONI, J. C.; TUCCI, C. E. M. Precipitação. In. TUCCI, C. E. M.(Org.) Hidrologia: ciência e aplicação. 2.ed. Porto Alegre: Universidade Federal do Rio Grande do Sul, 2001. p.177-242.

CASTRO, P. S. Influência da cobertura florestal na qualidade da água em duas bacias hidrogáficas na região de Viçosa, MG. 1980. 107p. Dissertação (Mestrado em Ciências Florestais) - Escola Superior de Agricultura "Luiz de Queiroz", Piracicaba, 1990. 
CASTRO, P. S.; VALENTE, O. F.; COELHO, D. T.; RAMALHO, R. S. Interceptação da chuva por mata natural secundária na região de Viçosa - MG. Revista Árvore, Viçosa, v. 7, n. 1, p. 76-89, 1983.

DALBEN, S. Mata atlântica: projeto promove educação ambiental e contribui para preservação desse ecossistema. Minas faz Ciência, Belo Horizonte, v. 27, n. 1, p. 24$25,2006$.

FERREIRA, S. J. F.; LUIZÃO, F. J.; DALLAROSA, R. L. G. Precipitação interna e interceptação da chuva em floresta de terra firme submetida à extração seletiva de madeira na Amazônia Central. ACTA Amazônica, Manaus, v. 35, n. 1, p. 55-62, 2005.

JOHNSSON, R. G. The interception, throughfall and stemflow in a forest in Highland Scotland and the comparison with other upland forests in the U.K. Journal of Hydrology, Amsterdam, v. 118, p. 281-287, 1990.

LIMA, P. R. A.; LEOPOLDO, P. L. Quantificação de componentes hidrológico de uma mata ciliar, através do modelo de balanço de massas. Revista Árvore, Viçosa, v. 24, n. 3, p. 241-252, 2000.

LIMA, W. P. Estudos de alguns aspectos quantitativos e qualitativos do balanço em plantações de eucaliptos e pinus. 1975. 111f. Tese (Doutorado em Ciência Florestal) Escola Superior de Agricultura "Luiz de Queiroz", Piracicaba, 1975.

NÁVAR, J.; BRYAN, R. Interception loss and rainfall redistriution by tree semi-arid growing shrubs in northeastern México. Journal of Hydrology, Amsterdam, v. 115, p. 51-63, 1990.

OLIVEIRA JR., J. C. Precipitação efetiva em floresta estacional semidecidual na Reserva Mata do Paraíso. 2006. 72f. Dissertação (Mestrado em Ciências Florestais) Universidade Federal de Viçosa, Viçosa, 2006.

RESENDE, S. B. Estudo de Crono-Toposequência em Viçosa, MG. 1971. 71f. Dissertação (Mestrado em Solos) - Universidade Federal de Viçosa, Viçosa, 1971. 